Portland State University

PDXScholar

\title{
The Geology of the Castle Rock Area, Grant, Harney and Malheur Counties, Oregon
}

John David Wood

Portland State University

Follow this and additional works at: https://pdxscholar.library.pdx.edu/open_access_etds

Part of the Geology Commons, and the Stratigraphy Commons Let us know how access to this document benefits you.

Recommended Citation

Wood, John David, "The Geology of the Castle Rock Area, Grant, Harney and Malheur Counties, Oregon" (1976). Dissertations and Theses. Paper 2608.

https://doi.org/10.15760/etd.2606

This Thesis is brought to you for free and open access. It has been accepted for inclusion in Dissertations and Theses by an authorized administrator of PDXScholar. Please contact us if we can make this document more accessible: pdxscholar@pdx.edu. 
AN ABSTRACT OF THE THESIS OF John David Wood for the Master of Science in Geology presented Apri1 $30,1976$.

Title: The Geology of the Castle Rock Area, Grant, Harney and Malheur Counties, Oregon.

APPROVED BY MEMBERS OF THE THESIS COMMITTEE:

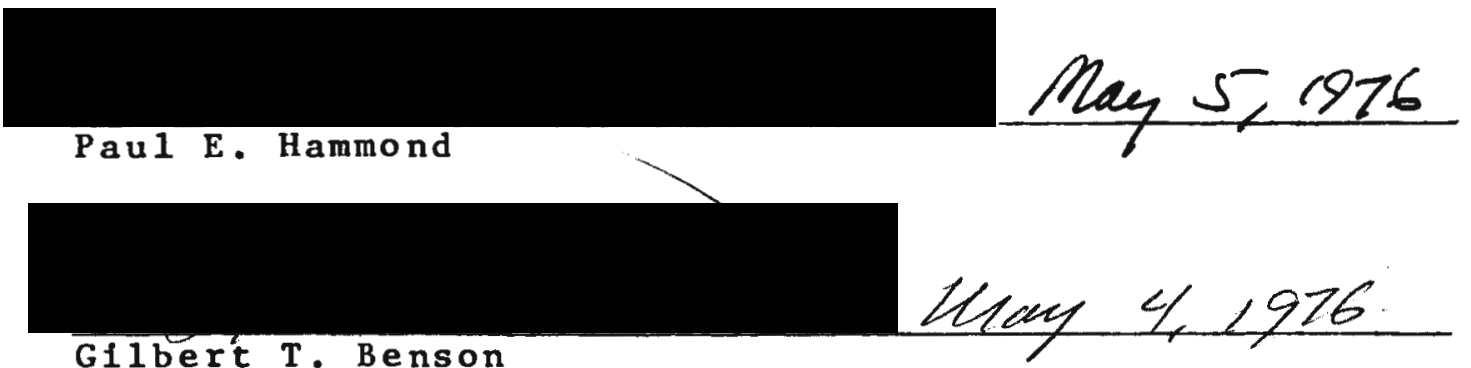

Gilbert T. Benson
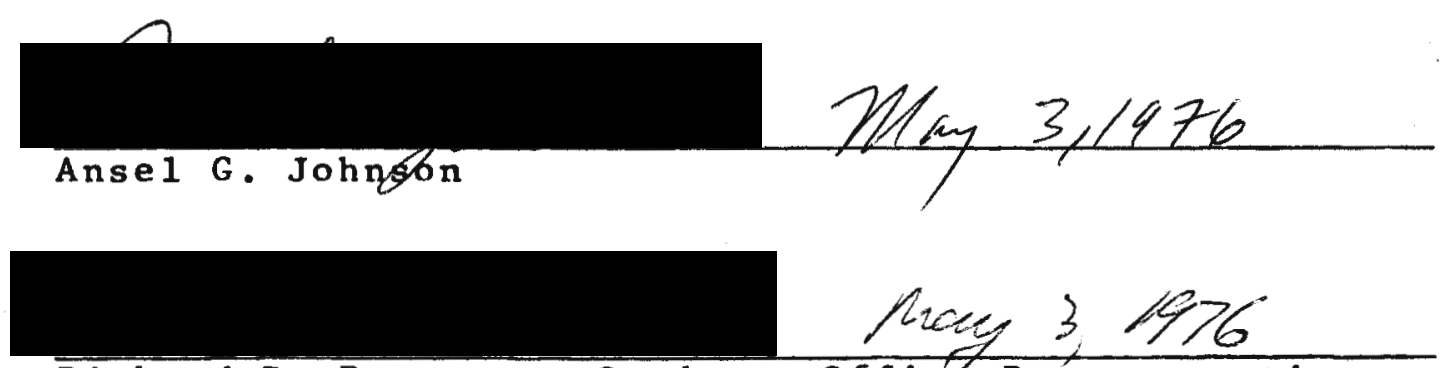

RIchard R. Petersen, Graduate Office Representative

The geology of the Castle Rock area aids in the understanding of Cenozolc volcanic stratigraphy and structures in an area where these volcanic rocks thin near the margins of the pre-Tertiary basement rocks and structural trends are overlapping. The Castle Rock area is unique in several aspects and is important in understanding and interpreting the geology in adjacent regions which have all been studied, at least on a reglonal basis. Intrusive ash-flow bodies of the 
Dinner Creek Ash-Flow Tuff, well-exposed sections of complex1y interstratified volcanic rocks and well-exposed faults, and of high amount of erosional relief are features which make this area a unique and important addition to the understanding of the stratigraphy of eastern oregon.

The Castle Rock area includes approximately $65 \mathrm{~km}^{2}$ occupying the area of intersection of Grant, Harney and Malheur Counties of eastern oregon. The products of this study are a geologic map of the area and stratigraphic and 1ithologic descriptions of the rock units within the area. The "unnamed Igneous complex" is the oldest rock unit exposed within the area. This complex consists of more than $670 \mathrm{~m}$ of flow-on-flow basaltic lava flows deposited in Late Miocene time. Faulting and intrusion of rhyolitic dikes resulted in the Castle Rock ridge being uplifted along numerous north-northwest-trending faults.

Eruptions of the Dinner Creek Ash-Flow Tuff from these rhyolitic dikes introduced numerous local volcanic structures and ultimately caused subsidence of the area around Black Butte. The resultant tuff sheet is more than $300 \mathrm{~m}$ thick local1y.

Sillcle lava flows and brecclas, pumice lapil11-tuffs and basaltic lava comprising a section more than $700 \mathrm{~m}$ thick, were deposited over the Dinner Creek Tuff in very Late Miocene time. These rocks, the Strawberry Volcanics, were derived from sources primarliy outside the Castle Rock area. Following folding, continued faulting and extensive 
3

erosion, the tuffaceous, lacustrine and fluviatile cedimints of the Juntura and Drewsey Formations and associated volcanic rocks were deposited through Early and Middle Pliocene time, respectively. A thin rhyolitic welded ashflow tuff was deposited during deposition of the Drewsey Formation.

During Pleistocene to Recent time faulting and folding have continued on a small scale and erosion of the lacustrine sediments has left stream deposits on pediment surfaces $470 \mathrm{~m}$ above the present stream level. 
TO THE OFFICE OF GRADUATE STUDIES AND RESEARCH:

The members of the Committee approve the thes 15 of

John Dav1d Wood presented April 30,1976 .
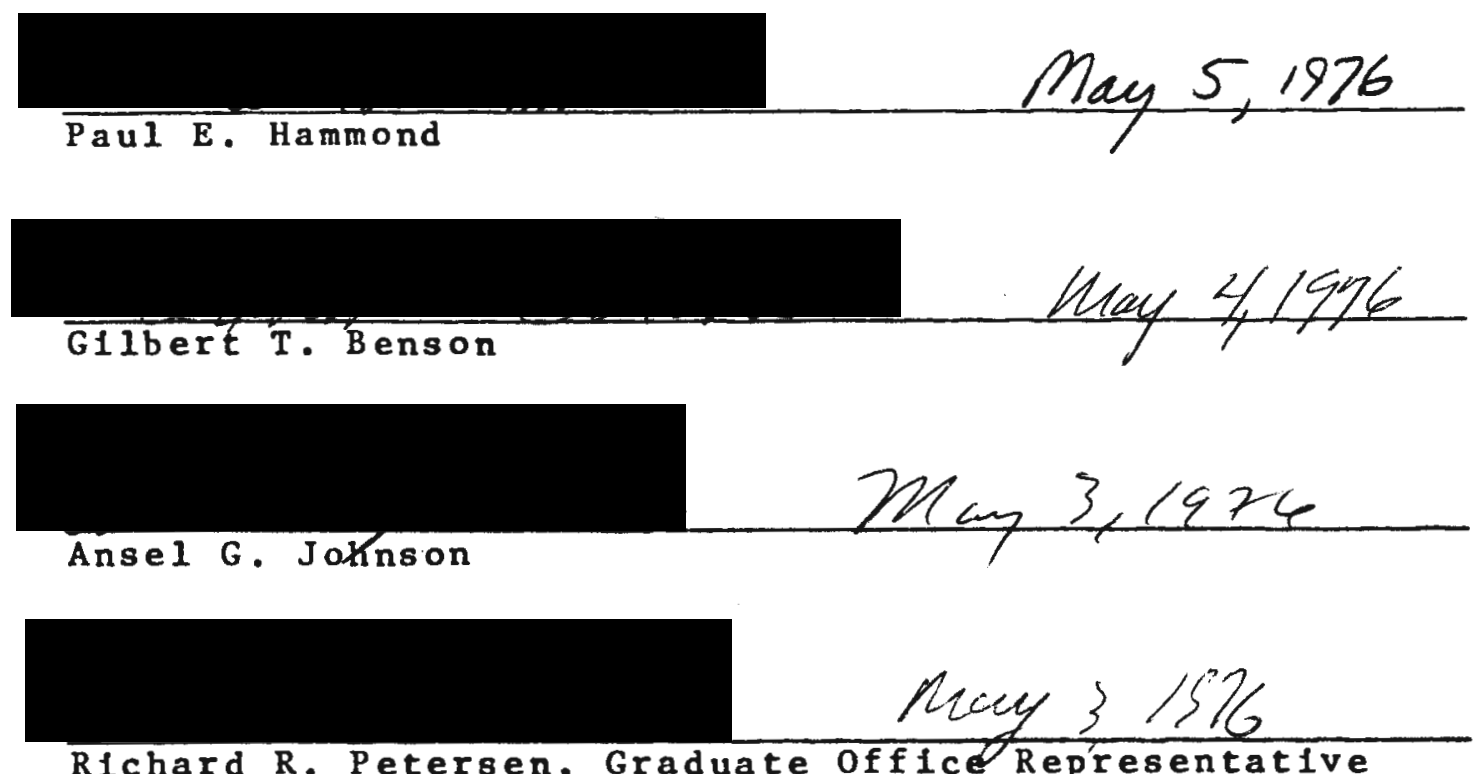

AP P ROVE D :

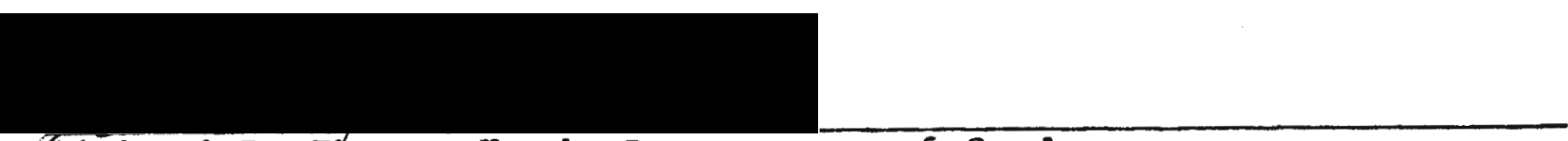

Richard E. Thoms, Head, Department of Geology

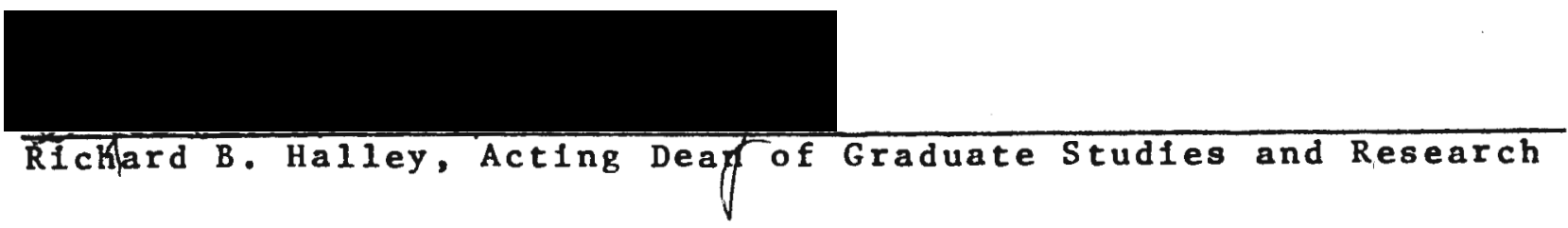

Apr11 30, 1976 
THE GEOLOGY OF THE CASTLE ROCK AREA,

GRANT, HARNEY AND MALHEUR COUNTIES, OREGON

by

JOHN DAVID WOOD

A thesis submitted in partial fulfillment of the requirements for the degree of

MASTER OF SCIENCE

In

GEOLOGY

Portland State University

1976 


\section{ACKNOWLEDGEMENTS}

The author gratefully acknowledges the assistance of all persons who have contributed both directly and indirectly to this study. A special thanks is due Paul E. Hammond, Chalrman of the Committee, for critically reviewing and editing the manuscript, and the Committee members, Gilbert $T$. Benson, Ansel G. Johnson, and Richard R. Peterson, for their proof-reading, editing, and numerous suggestions. Richard E. Thoms and John E. Allen, present and past Department Chairmen, also had input into this study.

The author is also indebted to H. Dean Pilkington, Regional Geothermal Geologist for Amax Exploration, Inc., for hours of stimulating discussion on stratigraphy and geologic processes. Also noteworthy of mention are the native inhabitants of the area, and especially the people of the Castle Rock Ranch, for their assistance.

The author is indebted to Frank Dellechale and exceedingly grateful to Harry J. 01son of Amax Exploration, Inc., for arranging the generous financial assistance for this project. 


\section{ABSTRACT}

The Castle Rock area Includes approximately $65 \mathrm{~km}^{2}$ occupying the area of intersection of Grant, Harney and Malheur Counties of eastern Oregon. The products of this study are a geologic map of the area and stratigraphic and lithologic descriptions of the rock units within the area.

The "unnamed Igneous complex" is the oldest rock unit exposed within the area. This complex consists of more than 670 m of flow-on-flow basaltic lava flows deposited in Late Mocene time. Faulting and intrusion of rhyolitic dikes resulted in the Castle Rock ridge being uplifted along numerous north-northwest-trending faults.

Eruption of the Dinner Creek Ash-Flow Tuff from these rhyolitic dikes introduced numerous local volcanic structures and ultimately caused subsidence of the area around Black Butte. The resultant tuff sheet is more than $300 \mathrm{~m}$ thick locally.

Silicic lava flows and brecclas, pumice lapilif-tuffs and basaltic lava comprising a section more than 700 m thick, were deposited over the Dinner Creek Tuff in very late Miocene time. These rocks, the Strawberry Volcanics, were derived from sources primarily outside the Castle Rock area. Following folding, continued faulting and extensive erosion, the tuffaceous, lacustrine and fluviatile sediments 
$1 v$

of the Juntura and Drewsey Formations and associated volcanic rocks were deposited through Early and Middle Pliocene time, respectively. A thin rhyolitic welded ash-flow tuff was deposited during deposition of the Drewsey Formation.

$$
\text { During Pleistocene to Recent time faulting and folding }
$$

have continued on a small scale and erosion of the lacustrine sediments has left stream deposits on pediment surfaces $470 \mathrm{~m}$ above the present stream level. 
TABLE OF CONTENTS

PAGE

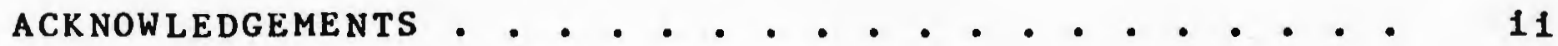

ABSTRACT..$\cdot$. . . . . . . . . . . . . 1111

TABLE OF CONTENTS . . . . . . . . . . . . . . . . . v v

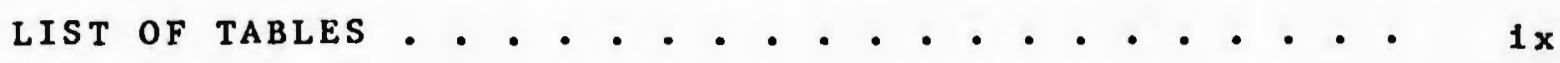

LIST OF FIGURES •

INTRODUCTION

LOCATION AND ACCESSIBILITY . . . . . . . . 1

PURPOSE OF INVESTIGATION . . . . . . . . . . . 4

PREVIOUS WORK . . . . . . . . . . . . . 4

FIELD WORK AND GENERAL PROCEDURE . . • • • . 4

GEOGRAPHIC SETTING . . . . . . . . . . . 6

Physlography . . . . . . . . . . 6

Geomorphic History . . . . . . . . 7

Culture . . . . . . . . . . . . 10

c11mate . . . . . . . . . . 10

Vegetation and W11d11fe . . . . . . 11

STRATIGRAPHY

SYNOPSIS . . . . . . . . . . . . . 13

REGIONAL CORRELATION . . . . . . . . . . 16

"UNNAMED IGNEOUS COMPLEX" . . . . . . . . . . 20 
PAGE

DEFINITION

DISTRIBUTION AND THICKNESS . . . . . . . . 22

LITHOLOGY . . . . . . . . . . . . . . 24

AGE AND CORRELATION

DINNER CREEK WELDED ASH-FLOW TUFF - • • . • . - 31

DEFINITION.$\cdot \cdot \cdot \cdot \cdot \cdot \cdot \cdot \cdot \cdot \cdot \cdot \cdot \cdot \cdot \cdot 31$

DISTRIBUTION AND THICKNESS . . . . . . . . . 31

GENERAL LITHOLOGY • • • • • • • • • • • • • 32

ZONATION . . . . . . . . . . . . . . . . 33

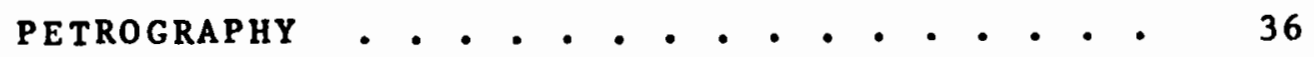

SOURCE AREAS . . . . . . . . . . . 38

AGE AND CORRELATION . . . . . . . . . . 45

STRAWBERRY VOLCANICS . . . . . . . . . . . . 46

DEFINITION . . . . . . . . . . . . . . . 46

DISTRIBUTION AND THICKNESS . . - . . . . $\cdot 47$

LITHOLOGY • . . . . . . . . . . . . 49

Rhyolitic Lava Flow and Breccia
Member... . . . . . . . . . . . 49

Basaltic to Dacitic Lava Flow
Member......... 50

Volcaniclastic Member . . . . . . . 52

olivine Basalt Member . . . . . . . . 54

AGE AND CORRELATION . . . . . . . . . . 55

JUNTURA FORMATION

DEFINITION . . . . . . . . . . . . . . . 56

DISTRIBUTION AND THICKNESS . . . . . . . . . 56

LITHOLOGY . . . . . . . . . . . . . 56 
Sedfmentary Strata. . . . . . . . . 57

Volcanic Strata . . . . . . . . . . 59

AGE AND CORRELATION . . . . . . . . . . . 62

DREWSEY FORMATION . . . . . . . . . . . . . . 63

DEFINITION . . . . . . . . . . . . . . . 63

DISTRIBUTION AND THICKNESS . . . . . . . . 63

STRATIGRAPHY . . . . . . . . . . . . . . . 64

AGE AND CORRELATION . . . . . . . . . . . 65

PL IOCENE TUFF PROBLEM . . . . . . . . . . . . 66

SURFICIAL DEPOSITS

ALLUVIAL FAN DEPOSITS . . . . . . . . . . 69

LANDSLIDE DEPOSITS • . . . . . . . . . . 69

COLluVIUM . . . . . . . . . . . . . . . . 71

ALluVial AND LACUSTRINE DEPOSITS . . . . . . . 72

HYDROTHERMAL ALTERATION . . . . . . . . . . 74

STRUCTURAL GEOLOGY - . . . . . . . . . . . 75

INTRODUCTION . . . . . . . . . . . . . . . 75

FOLDING . . . . . . . . . . . . . . . 75

FAULTING

STRUCTURAL SYNTHESIS . . . . . . . . . . . . 77

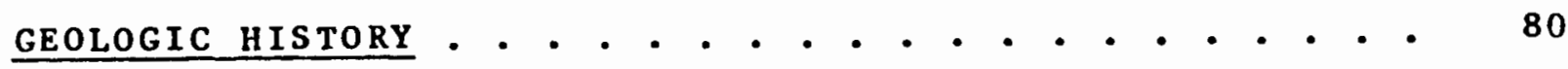

REFERENCES CITED . . . . . . . . . . . . . . . . . . . 83

APPENDICES • . • . . . . . . . . . . . . . . . 90

APPENDIX A (MEASURED STRATIGRAPHIC SECTIONS) • • • 90

Section 1 - "Unnamed Igneous Complex" . . . 90 
v111

PAGE

Section 2 - Strawberry Volcanics . . . . . 99

Section 3 - Juntura Formation . . . . . 107

APPENDIX B (GLASS-BEAD SILICA DETERMINATIONS) • 115

Introduction

Pract1ca1 Appl1cat1on . . . . . . . . 117

General observations . . . . . . . . . . 121 


\section{LIST OF TABLES}

TABLE

PAGE

1 Modal Compositions of Basalts of the

"Unnamed Igneous Complex" . . . . . . . 28

2 Summary of Glass-Bead Sillca Analyses. . . 119 


\section{LIST OF FIGURES}

FIGURE

PAGE

1 Index Map of the Castle Rock Area..... . 2

2 Topographic Map of the Castle Rock Area.. 3

3 Index Map of the Castle Rock Area and Nearby Geologically Mapped Areas... .

4 Pediments Along the North-Fork of the Malheur River. . . . . . . . . .

5 Composite Stratigraphic Section of

the Castle Rock Area. . . . . . . . 14

6 Geologic Sketch of Castle Rock and

Looking Northward . . . . . . . . 15

7 Regional Correlation Chart . . . . . . . . 18

8 Correlated Stratigraphic Sections of the

"Unnamed Igneous Complex" . . . . . . 21

9 Reference Section and Marker Bed Within

the "Unnamed Igneous Complex" . . . .

10 Measured Stratigraphic Section of the

"Unnamed Igneous Complex" . . . . . . 26

11 Lateral and Vertical Zonation with the

Dinner Creek Ash-Flow Tuff . . . . . 34

12 Xenolith Within the Castle Rock Dike . . $\quad 39$

13 View of the Castle Rock Dike Looking

Southwestward . . . . . . . . . . 
14 Vlew of the South End of Castle Rock Dike. . 41

15 Ramping Structures in Dinner Creek

$$
\text { Ash-Flow Tuff . . . . . . . . . . . . } 43
$$

16 Cross-Section of Castle Rock Dike and

Relationship of Near Vent Structures. . . 44

17 Measured Stratigraphic Section of Strawberry

$$
\text { Volcantcs . . . . . . . . . . . . . . } 48
$$

18 Jolnting in Lava Flows of the Strawberry

Volcanics . . . . . . . . . . . . . 53

19 Measured Stratigraphic Section of Sedimentary

Rocks of Juntura Formation... . . . . 58

20 Hinge Faults Through Volcanic strata of the

Juntura Formation . . . . . . . . . . 60

21 Measured Stratigraphic Section of Volcanic

Rocks of Juntura Formation . . . . . . 61

22 Break-Away Scarp of the Castle Rock

Landslide . . . . . . . . . . . 70

23 Slump Block of the Castle Rock Landslide. . . 70

24 Small-Scale Normal Faulting Along Lost Creek. 78

25 A Serles of Stepped Fault Blocks Near

Irish Spring . . . . . . . . . . . 78

26 Glass-Bead Silica Determinations for the

Castle Rock Area Compared with the

Owyhee Plateau . . . . . . . . . . 116 
27 Silica Distribution of Glass Bead Samples

of the Castle Rock Area . . . . . . . 118

\section{GEOLOGIC PLATE}

PLATE

1 Geologic Map of the Castle Rock Area ... In Pocket 


\section{INTRODUCTION}

\section{LOCATION AND ACCESSIBILITY}

The Castle Rock area covers a region of about $65 \mathrm{~km}^{2}$ occupying the area of intersection of Grant, Harney and Malheur Counties of eastern Oregon (Fig. 1). The area is a rugged volcanic upland with a topographic relief of about $1,170 \mathrm{~m}$.

The nearest hard-surfaced road, U. S. Highway 20 , is about $32 \mathrm{~km}$ to the south of the thesis area. From Highway 20, at the west end of the town of Juntura, a maintained gravel road leads to Beulah Reservolr near the southwest corner of the thesis area. From the reservoir three unimproved dirt roads traverse the area (Fig. 2). Two of these roads are within the thesis area, one paralleling the North Fork of the Malheur River and Little Malheur River Valleys to Black Butte where it degrades into a jeep trail on the western margin of the area. The other is a mountain road through the center of the thesis area, which eventually leads to the town of Ironside. A third road leading past the abandoned Hunter Ranch parallels the eastern boundary of the area. These dirt roads are all seasonably impassible in times of heavy rain or snow. In all weather, travel is easiest in a four-wheel drive, high clearance vehicle, though not always possible. 


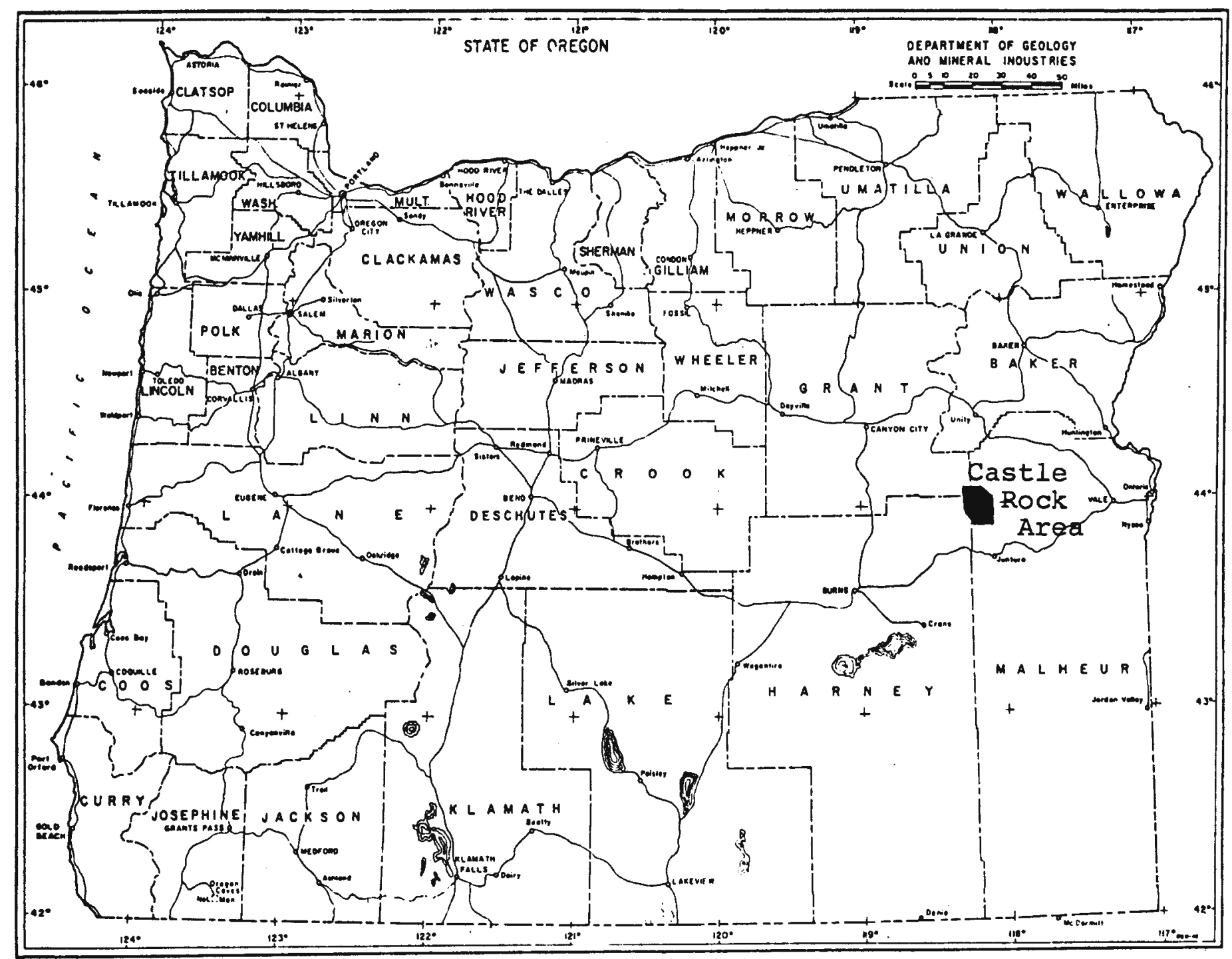

Figure 1. Index map of the Castle Rock area. 


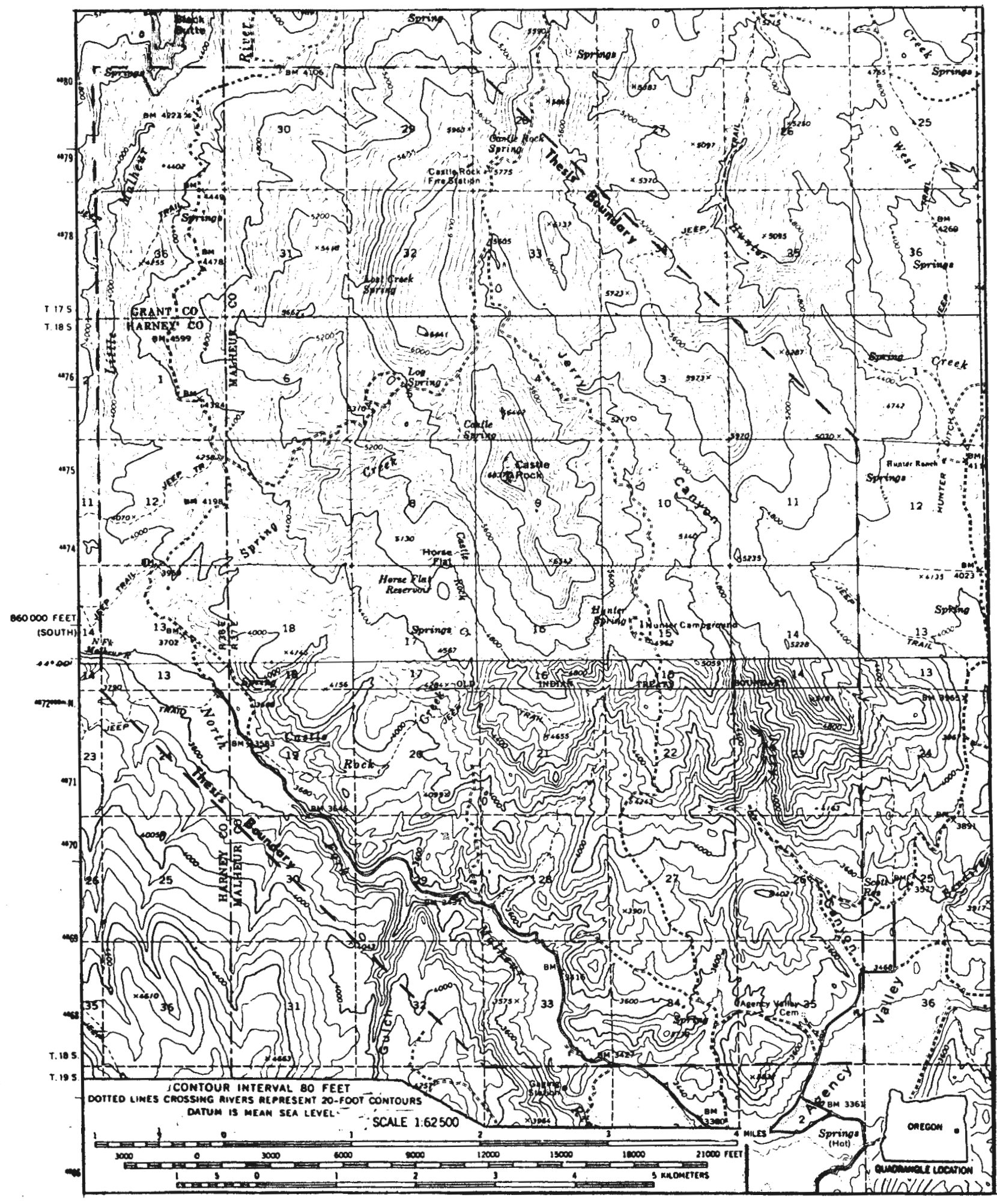

Figure 2. Topographic map of the Castle Rock area, showing main access roads. 
PURPOSE OF INVESTIGATION

This thesis was undertaken as a detalled mapping profect in order to fill in some unmapped terrain between previously mapped areas and supply more geologic information and stratigraphic control to a composite geologic map of regional scale prepared for Amax Exploration, Inc.

Beyond describing the lithology, geologic structure and development of landforms, an attempt has been made to comment on the work and 1deas of previous investigators. Interpretations and correlations aremintmal, but an effort is made to bring the geology of the area into a regional picture with respect to previous investigations.

\section{PREVIOUS WORK}

Geologic investigations around the Castle Rock area have been quite limited until recent years. The most recent mapping projects are summarized in Figure 3. Contributions by other workers are cited in the main body of the text and are listed in the reference section of the report.

FIELD WORK AND GENERAL PROCEDURE

Field work was begun in December 1974 after library Investigations and construction of a regional geologic map from the literature. Field work was intermittent unt 1 June 1975. From June to late August field work was continuous. Final field work was completed by November 1975. 


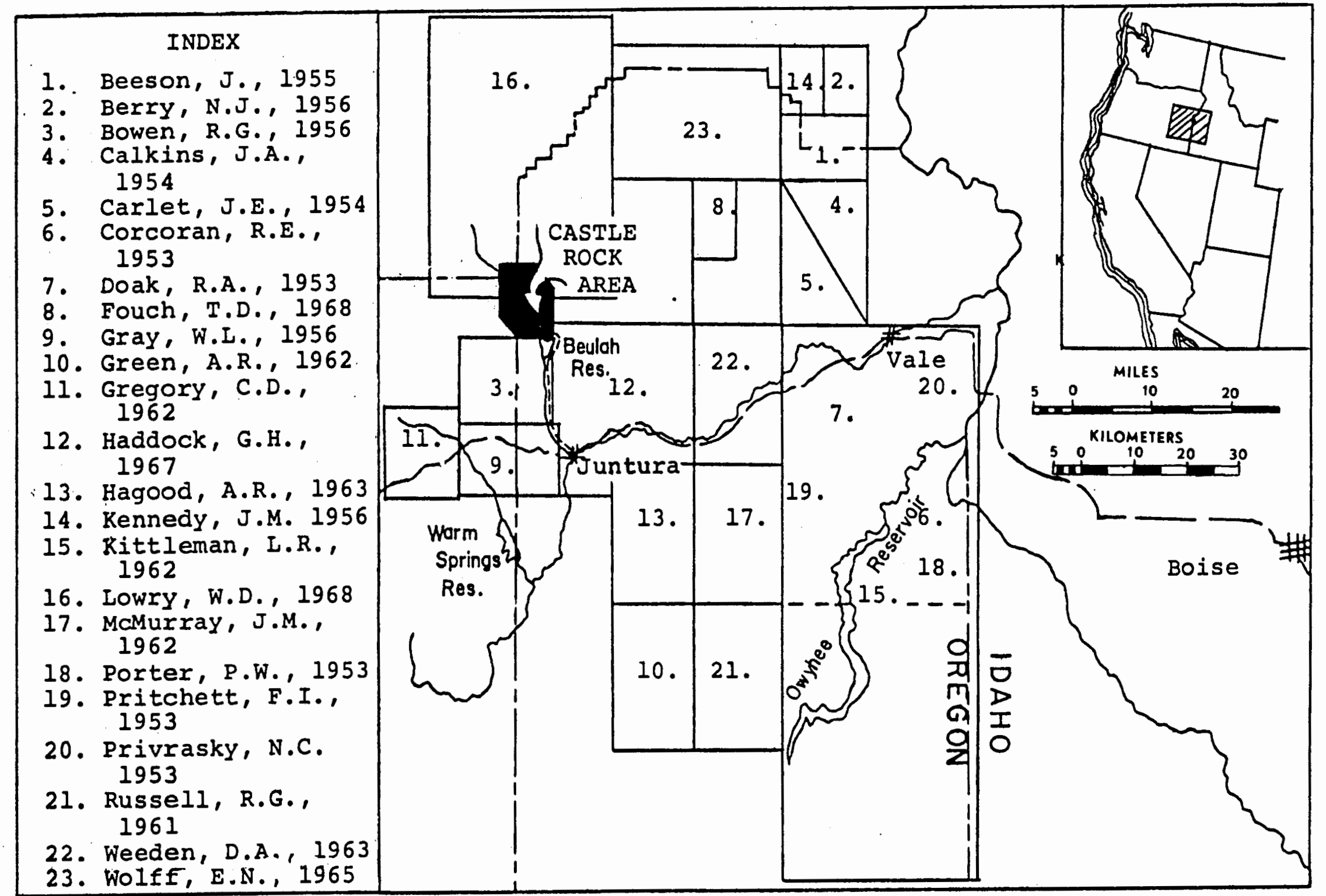

Figure 3. Index map of the Castle Rock area and nearby geologically mapped areas. 
The topographic base for the geologic map was constructed from four U. S. Geological survey preliminary sheets at a scale of 1: 24,000 with a contour Interval of $40 \mathrm{ft} .(13.3 \mathrm{~m})$. These maps cover the southern half of the Castle Rock $15 \mathrm{~min}$. quadrangle. Aerlal photographs obtalned from the U. S. Department of Agriculture greatly facilitated mapping. These photos were from a 1969 flight at a scale similar to the base map. Field map data was transferred to a base map in the fleld. Geologic contacts were located on the basis of topographic expression and rarely by triangulation. The completed geologic map (Plate 1, in pocket) is the foundation of this report and is referred to In later sections. About 40 thin sections were studied in order to refine hand specimen Identifications. Glass-bead sllica determinations were performed for correlation purposes and in order to obtain compositional control on black glassy lava flows for classification purposes.

\section{GEOGRAPHIC SETTING}

Physiography

The thesis area includes the southernmost extension of the Strawberry Mountains which border the Owyhee Upland to the southeast. Castle Rock at an elevation of $2,280 \mathrm{~m}$ is the highest point in the area and Beulah Reservolr at an elevation of $1,080 \mathrm{~m}$ is the lowest. Local relief in Jerry Canyon and the Canyon of the Little Malheur River may be over 130 m locally, with near vertical canyon walls. 
The rugged topography of the Castle Rock area is the result of uplift accompanylng volcanlsm, extensive faulting and erosion. High ridges and deep canyons reflect a north or northwest structural orientation. Lithology also plays an important part in controlling topography. Broad, gently sloping grassy plains have been formed on the dip slopes of lava flows. Soft volcanic and tuffaceous sediments of the southern part of the area form low, rounded hills, with a few prominent cliffs formed by interbedded ash flows and basalt flows.

All of the streams within the Castle Rock area are, at least in part, controlled by faulting. The main streams which skirt the eastern and western margins of the area have relatively low gradients and cause little erosion when not in flood stages. Streams draining the interior of the region have much higher gradients. Jerry Canyon, for instance, drops nearly $470 \mathrm{~m}$ in a distance of only $8.3 \mathrm{~km}$, a gradient of over 5.7 percent. All of the interfor streams are fed by springs which are commonly associated with faults, landsildes or geologic contacts.

Geomorphic History

Evidence of erosion persists throughout the geologic record in the Castle Rock area. The frregular relief developed on the lava flows on the unnamed lgneous complex and associated Interbedded stream gravels are good examples. All rocks in the area show signs of past erosion or reworking by 
sedimentary processes.

Evidence of the oldest lake existing within the area is the lacustrine sediments of the Juntura Formation. Erosion of these lacustrine sediments formed the frregular topography onto which the ash-flow tuff of the Drewsey Formation was deposited. This ash-flow sheet flowed Into a wide valley very simflar to that of the present valley of the North Fork of the Malheur River. Several small step-toes remained protruding through the sheet. This sheet probably flowed into the area from the south and its northward progress was stopped by the topographic barrier posed by the Castle Rock ridge system (Plate 1). A thin layer of lacustrine and fluviatile sediments was deposited over the ash sheet and only erosional remnants of these are found today. This period of erosion probably began in Middle Pliocene time and has continued to the present. Extensive pediments of Plefstocene age were cut into the soft sediments in the southwest corner of the area (FIg. 4, Plate 1). Landslides developed in valley walls because of over-steepened slopes caused by erosion and faulting and a high water level. At least one erosional remnant of a Pleistocene alluvial fan exists today over $470 \mathrm{~m}$ above the present stream level southeast of Horse Flat. Uplift of the area and subsequent down-cutting of streams resulted in the formation of the present topography. Youthful landslides and alluvial fans have formed along the present streams at their new base level. 


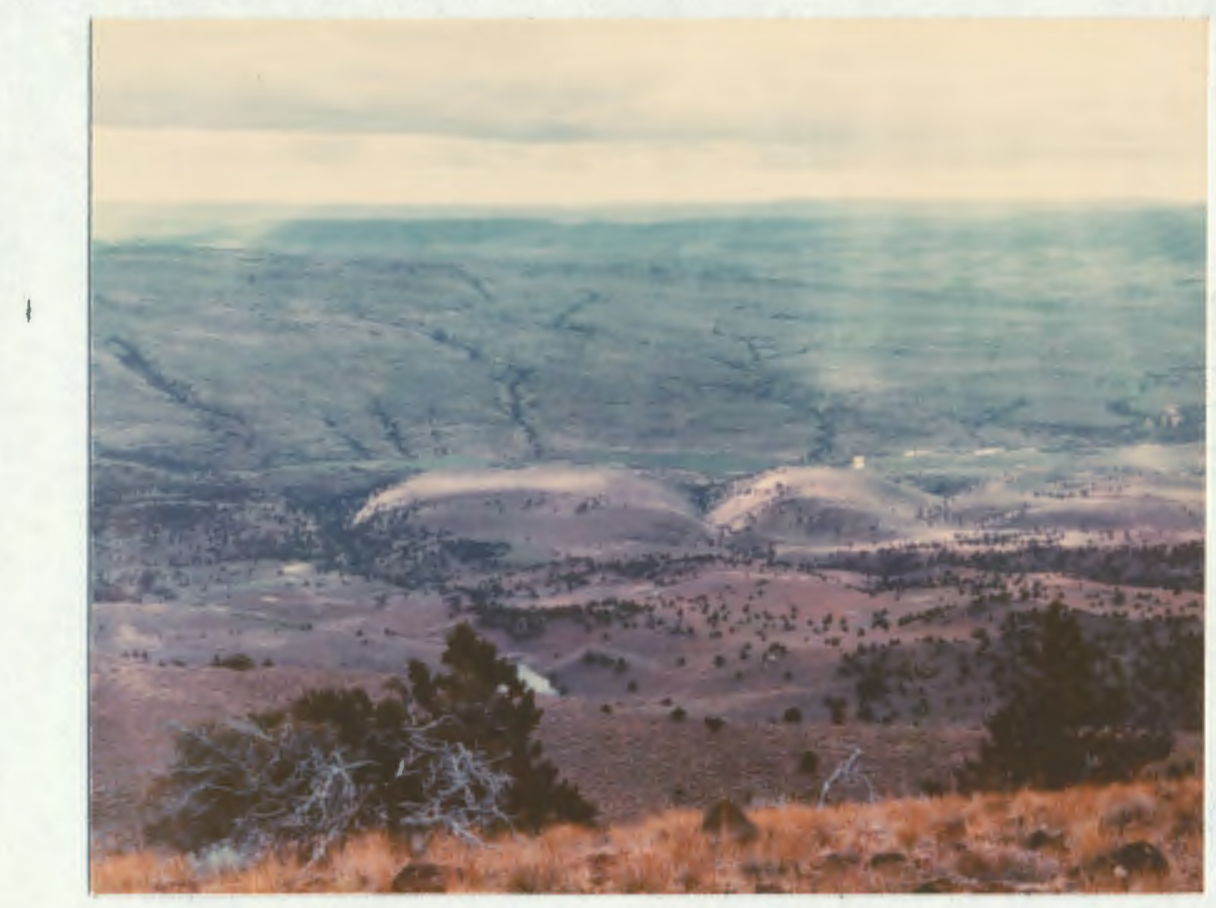

Figure 4. Pediments formed along the North Fork of the Malheur River looklng. westward from the base of Castle Rock. The low bench in the foreground is the upper surface of the Castle Rock landsilde. 


\section{Culture}

Several ranches prosper in the valleys of Warm Springs Creek and the North Fork of the Malheur River on the eastern and western margins of the thesis area. Agriculture is limited to the flat, easily irrigated areas, although dry farming techniques have been successful on the pediments above the valley floors. Elsewhere, agriculture is very limited due to steepness of terrain, insufficient water, poor soll conditions, or other factors. Water for irrigation comes from the permanent streams and reservolrs. Alfalfa is the major crop and is utilized as winter feed for cattle. Cattle raising is the dominant industry of the area. Most land is managed by the Bureau of Land Management, although much of the best agricultural land, near water sources, is privately owned. The total permanent population of the area is about 15 persons.

\section{Climate}

The climate of the Castle Rock area is generally cold and semi-arid. Low annual preclpitation of about $25 \mathrm{~cm}$ is probably due to the rainshadow effect of the high mountain ranges to the west.

Castle Rock 1tself, being a 2,084 m tall peak surrounded by much lower lava plains, is effective at disturbing eastward moving weather fronts and recelves slightly more precipitation and windy conditions. Storm systems in winter months 
come predominantly from the northwest and in the summer from the southwest. Seasonal and diurnal temperature variations are large. The maximum yearly temperature variation is from about $43^{\circ} \mathrm{C}$ to about $-34^{\circ} \mathrm{C}$, a total of $77^{\circ} \mathrm{C}$. Diurnal temperature variations are most extreme in the summer and may vary by as much as $43^{\circ} \mathrm{C}$.

Most precipitation occurs from October to June in the form of snow. In summer months precipitation comes in the form of sudden heavy ralns from thunder showers. In winter months temperatures of ten remain below freezing for many days and the large Beulah Reservolr commonly freezes over.

Vegetation and W1ldife

The vegetation of the Castle Rock area ls controlled by soll type, avallability of water, elevation and exposure to the sun. Vegetative cover ranges from flat laying grasslands to dense forests. Heavy forests of pine and fir are common on eastern mountain slopes, whlle only juniper and mountain mahogany can tolerate the intense heat and winds which make the western slopes sparsely vegetated. Dead juniper and mahogany within the pine and fir forest suggest that 1 t 1 growing at their expense. Sage and w1ld grasses grow wherever heavy tree cover does not exist. Many species of lichen are present and are most apparent after thunder showers when they brighten in color and make footing quite slippery. Poplar trees, willows and other plants requiring considerable molsture serve as markers for springs and areas 
12

of high water table.

Most of the animal population is active only in early morning and evening hours and may only be seen in midday by disturbing their natural routine. Mammals present in the Castle Rock area Include deer, bear, wildcats, badgers, coyotes, porcupines, skunks, jack rabbits, numerous squirrels and small rodents. Birds represented include chukar, partrudge, sage hen, dove, duck, qua 11, pheasant, red-winged blackbird, western meadowlark, Canadian goose, robin, burard, eagle, hawk, raven, western magpie and scrub fay. In sumer months several types of 11 ards and snakes are bundante. Rattlesnake and milk boa are the most prevalent snakes. 


\section{STRATIGRAPHY}

\section{SY NOPSIS}

The oldest rocks exposed in the Castle Rock area consist of a thick sequence of basaltic lava flows and related pillow palagonite brecclas termed the "unnamed igneous complex" (Tulc). These rocks have a thickness of at least $670 \mathrm{~m}$ and an areal extent of about $5 \mathrm{~km}^{2}$ within the thesis area (Fig. 5, Plate 1).

The Dinner Creek welded tuff (Tdc) unconformably overlies the "unnamed Igneous complex" and was erupted from fissure vents represented by Castle Rock and Black Butte (Haddock, 1967; Fig. 6). At the base of this unit is a nonwelded pumice-lapilil-tuff (Tdcp) which is restricted to one exposure southwest of Castle Rock. The Dinner Creek has a minimum thickness of $250 \mathrm{~m}$ and has an areal extent of greater than $7 \mathrm{~km}^{2}$.

The Strawberry Volcanics is the most complex lithologic unit within the Castle Rock area and unconformably overlies the Dinner Creek Tuff. The Strawberry Volcanics are subdivided into four members: a rhyolitic breccla and flow member interbedded low in the section (Tsvr), the basaltic to dacitite lava flows comprising the bulk of the section (Tsv), a volcaniclastic member (Tsvv) which includes a pumice lap1111-tuff marker bed (Tsvm) that was also mapped separately, and three 


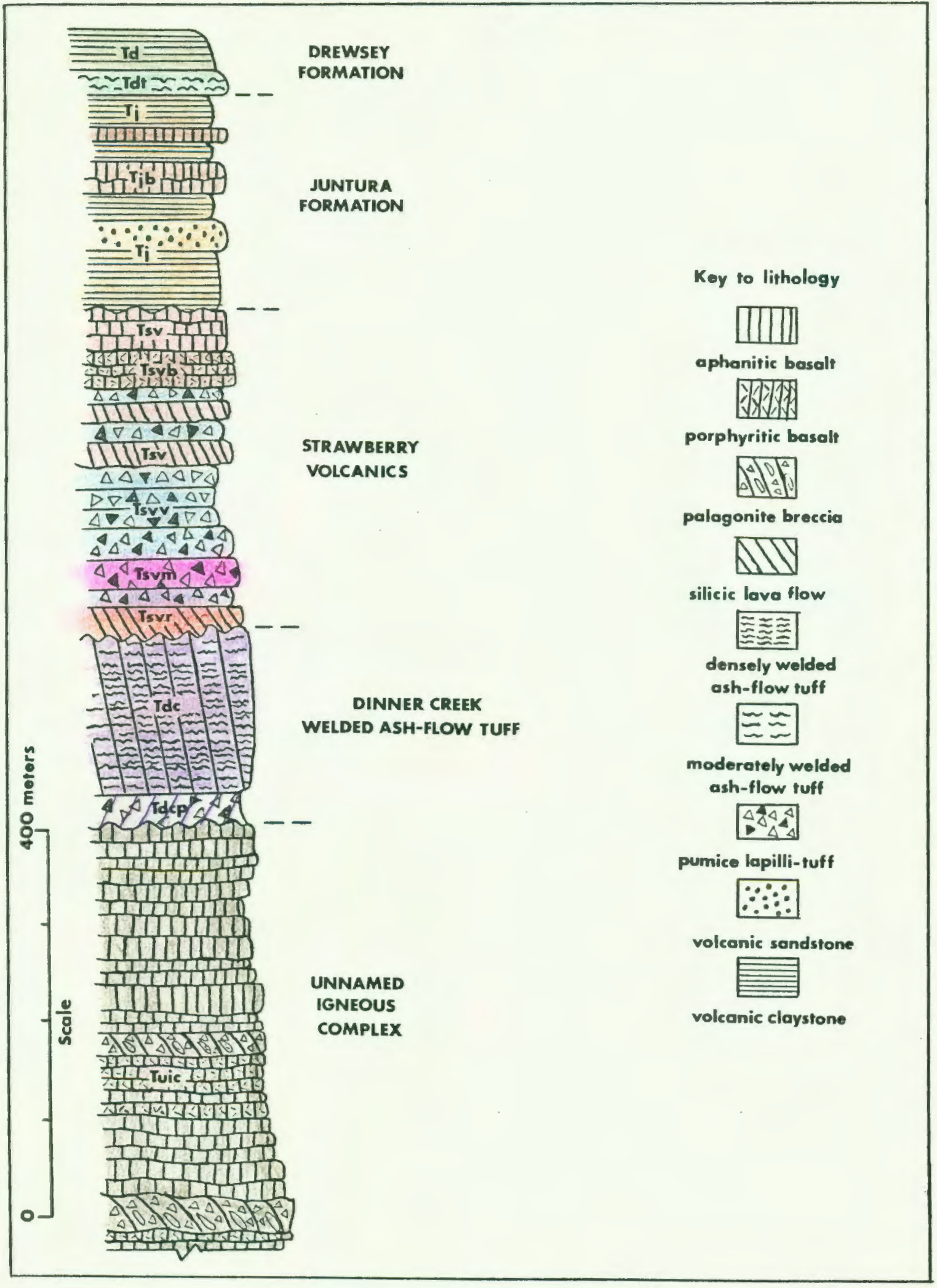

Figure 5. Composite stratigraphic section of the Castle Rock area (and color key for figure 6.). 
thin olivine basalt flows high in the section (Tsvb). The Strawberry Volcanics have a total aggregate thickness of at least $400 \mathrm{~m}$ and an areal extent of about $20 \mathrm{~km}^{2}$ within the thes is area.

The Juntura Formation ( $T f$ ) unconformably overlies the Strawberry Volcanics in the southern part of the thesis area. This formation consists of more than $200 \mathrm{~m}$ of $11 \mathrm{ght}-\mathrm{b} r \mathrm{own}$ tuffaceous sediments and interbedded air-fall deposits (Tf), and basalt lava flows ( $\mathrm{T} f \mathrm{~b}$ ) covering an area of about $20 \mathrm{~km}^{2}$. The Drewsey welded tuff (Tdt) and sedimentary strata of the Drewsey Formation ( $T d$ ) overlie the Juntura Formation. These rocks have an areal distribution of about $4 \mathrm{~km}^{2}$ in the southwest corner of the thesis area and have a thickness as great as $25 \mathrm{~m}$ locally.

\section{REGIONAL CORRELATION}

The stratigraphic units of the Castle Rock area are all of Late Mlocene and Early Pllocene age, but less than $2 \mathrm{~km}$ to the north much older basement rocks are exposed. These basement rocks consist of Upper Paleozolc and Lower Mesozolc eugeosynclinal sedimentary and volcanic strata as described by Brown and Thayer (1966) and Lowry (1968). All of these pre-Tertlary rocks show signs of deformation by several orogenies and have been intensely metamorphosed in places, primarily adjacent to intrusions. The products of metamorphism are predominantly schists, slates and greenstones which resulted from emplacement of both sillcic and mafic intrusions. 
The "unnamed Igneous complex" is the oldest rock unft exposed in the Castle Rock area and the adjacent regions to the west, south and east. In one of the earliest organized Investigations, the "unnamed igneous complex" was included in a super unit termed the "Basement Complex," (Bowen, Gray and Gregory, 1963). The "Basement Complex" Included such units as the Dinner Creek Ash-Flow Tuff, Littlefield Rhyolite, Hunter Creek Basalt, and other units which have since received formal formational status by Kittleman (1965). Flows of the "unnamed Igneous complex" are those below the (Dinner Creek) welded ash-flow tuff marker bed of the "Basement Complex." Similarly, flows of this complex were included in the lower part Strawberry Volcanics, as mapped by Brown and Thayer (1966 and 1973) within the Castle Rock area. Lowry (1968) may have mapped the lower porphyritic flows and brecclas of the "unnamed Igneous complex" as RIng Butte andesite and the younger dark gray lavas as Columbla River Basalt where the Dinner Creek Marker Bed was not obviously overlaying both of them (Fig.7).

The Dinner Creek Tuff was first mapped by Lowry (1943) with other rhyolitic lava flows and breccias as "Dooley Rhyo11te." Bowen (1956) and Gray (1956) referred to it as the welded tuff member of the Owyhee Basalt, a designation which was changed to welded tuff within the "Basement complex" by Bowen, Gray and Gregory (1963).

The older rhyolitic lavas of the Strawberry Volcanics as mapped in this report were included in with the "Dooley 


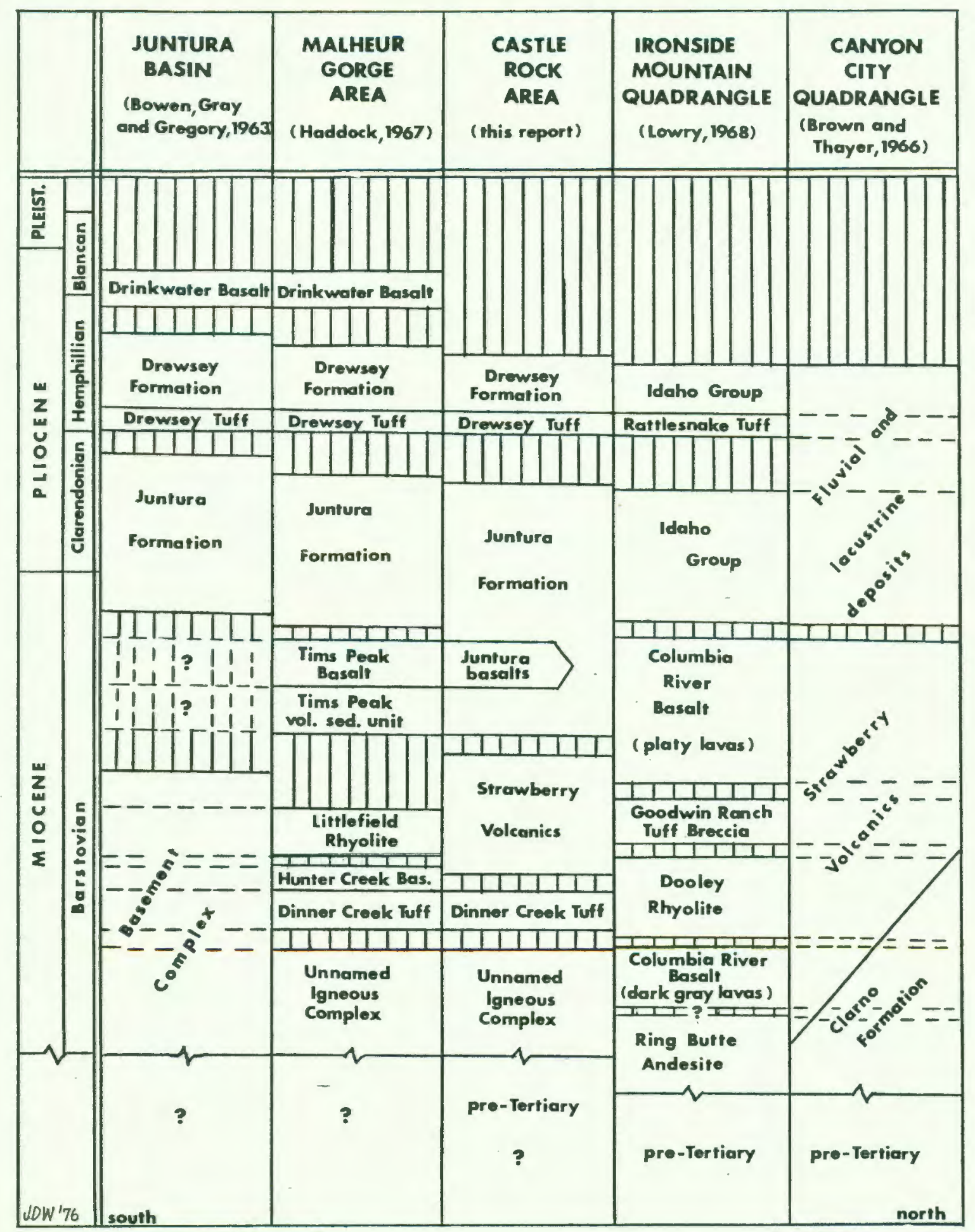

Figure 7. Regional correlation chart of principal stratigraphic units and nomenclature used in this report and previous investigations. 
Rhyolfte" by Lowry (1968) and were mapped as Littlefield Rhyolite by Haddock (1967). Younger lava flows of the Strawberry Volcantcs were Included in the "Basement Complex" of Bowen and others (1963) and the Columbla River Basalt by Lowry (1968). The volcaniclastic member of the Strawberry Volcanics was mapped as "Goodwin Ranch Tuff Breccla" by Lowry (1968).

The Juntura Formation is equivalent to the lower part of the Idaho Group as mapped by Lowry (1968). The basalts Interbedded within the lower part of the Juntura Formation are equivalent to the Tims Peak Basalt as mapped by Haddock (1967). The lower part of the Juntura Formation, below the basalt flows, is equivalent to the "Tims Peak rolcanic and sedimentary unit" of Haddock (1967).

The welded tuff at the base of the Drewsey Formation may be correlative with Rattlesnake Tuff of the John Day Basin (Bowen and others, 1963) and was mapped as Rattlesnake Tuff by Lowry (1968), even though he recognized lithologic and stratigraphic differences. 


\section{"UNNAMED IGNEOUS COMPLEX"}

DEFINITION

The interstratified mafic lava flows and breccias of the "unnamed igneous complex" ( $T u 1 c$ ) were first described by Hagood (1963), and subsequently by Kittleman and others (1965) and Haddock (1967). The base of the "unnamed 1gneous complex" has never been described, but it is exposed a short distance north of the Castle Rock area overlying pre-Tertiary strata. Regionally this complex is exposed over an area in excess of $2,000 \mathrm{~km}^{2}$ and within the Castle Rock area has a minimal thickness of $650 \mathrm{~m}$. Since this unit has never attained formational status and no type section has been described, two correlated sections have been measured; either might make a sultable type section (FIg. 8). Both of these sections are over $350 \mathrm{~m}$ in thickness with relatively little structural complication.

The "unnamed Igneous complex," Owhyee Basalt and the Steens Mountain Volcanic Series, while similar in age, may never be proven to be part of one continuous unit because of extensive erosion, vast amounts of overburden, and the stratigraphic and lithologic variability of the individual flows. These lava flow complexes are not composed strictly of flood basalts. Individual flows in the Castle Rock area are not traceable for more than a few kllometers and it is 


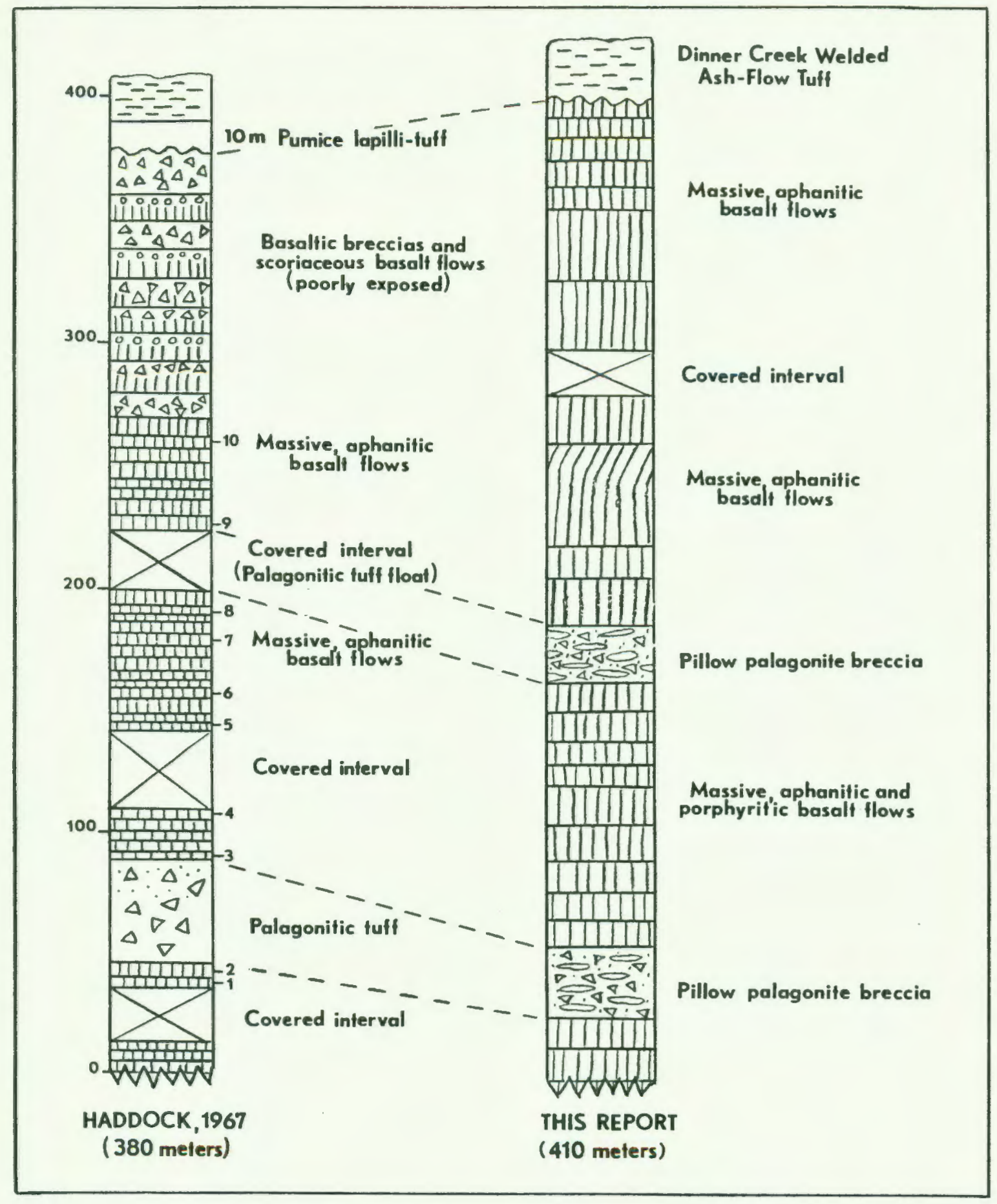

Figure 8. A comparison of reference sections from Haddock (1967) measured in the SW $1 / 4$ sec. 34, T. $20 \mathrm{~S} ., \mathrm{R} .30 \mathrm{E}$. and the section measured at Hunter Campground of this report in sections 15 and 16 , T. $18 \mathrm{~S} ., \mathrm{R} .37 \mathrm{E}$. 
believed they represent smaller pahoehoe flows, which were erupted from scattered central vents and fissures. Based on measurements in the Castle Rock area, flows average $15.3 \mathrm{~m}$ in thickness and may range from 10 to $150 \mathrm{~km}^{2} 1 \mathrm{n}$ areal extent. The complex is formed from many such overlapping and interfingering pahoehoe flows. The $11 \mathrm{~m}$ ted areal extent, stratigraphic and petrologic variability of these flows precludes flow-by-flow correlation of outcrops separated by more than $45 \mathrm{~km}$ of exposureless area.

Formal naming of this unit in the future will foster more detalled stratigraphic work, standardize past terminologies and eliminate confusion as to the exact relationships between the mafic lava complexes of eastern oregon. It is suggested that the term "Igneous" is too broad and vague, and might be replaced with the term "volcanic" which is more prec1se. Due to the regional extent of this unit, it might be named after Malheur Gorge, where the best exposures are present and it was first described (e.g., Malheur Gorge Volcanic Complex).

\section{DISTRIBUTION AND THICKNESS}

Within the Castle Rock area strata of the "unnamed Igneous complex" are restricted to the central and western portions of the mapped area (Plate 1) covering an area of about $5 \mathrm{~km}^{2}$. In the central portion of the mapped area these rocks form a structural high, uplifted along fault zones. In 


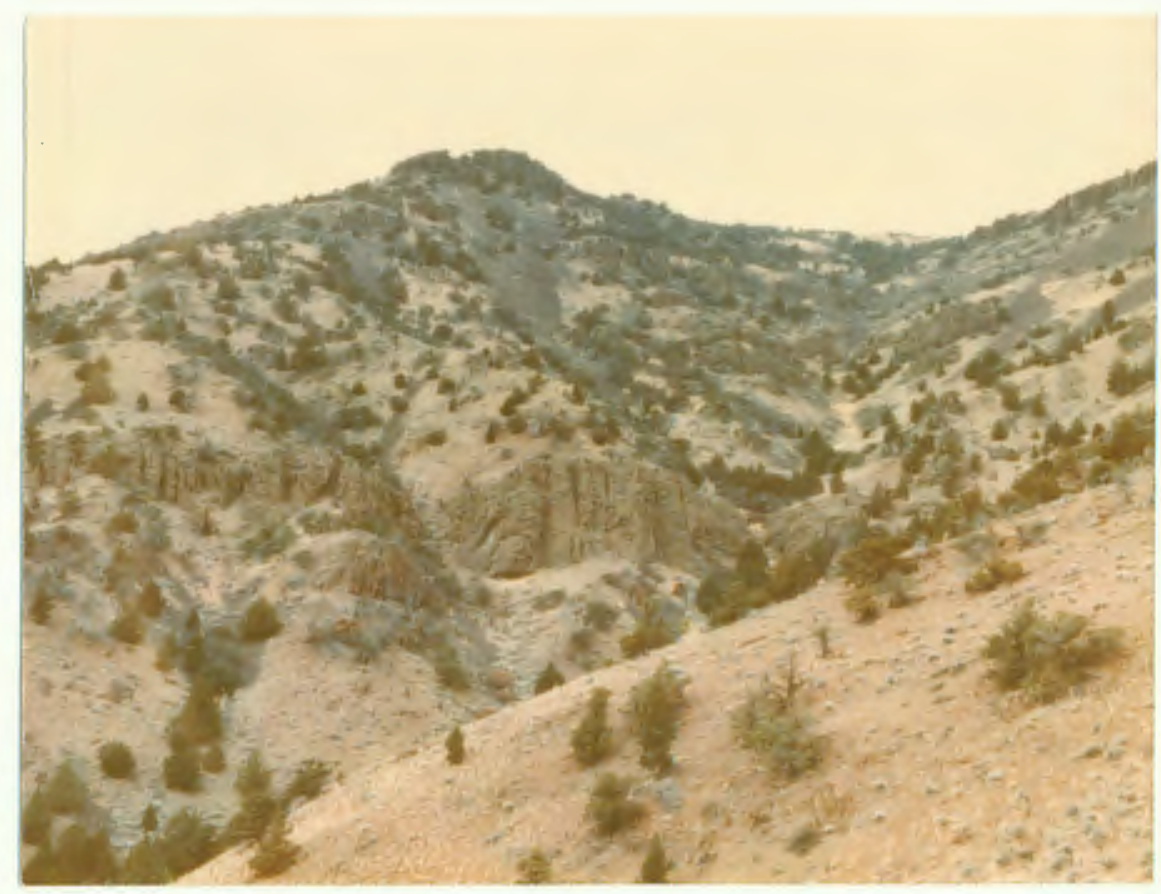

Flgure 9. Lava flows of the "unnamed Ingeous complex" exposed at the south end of the Castle Rock ridge, where the reference section was measured (secs. 15 and $\left.16, T .18 \mathrm{~S}, \mathrm{R}_{0} 37 \mathrm{E}.\right)$. The approximate traverse 11 ne appears on the left side of the photo. The p1llow palagonite breccla (unit 3, Fig. 10 and App. A, sec. 1) In the lower foreground was used as a marker bed. 
the western regions these rocks are exposed in the walls of deep canyons. At the south end of the Castle Rock ridge, the "unnamed Igneous complex" has a total thickness exceeding $650 \mathrm{~m}$. Here, at Hunter Campground, a reference section of over $410 \mathrm{~m}$, contalning 25 individual flows, was measured (F1g. 9).

The base of the "unnamed igneous complex" is not exposed in the Castle Rock area, nor has it been described in the literature, but flows of this unit lap up against and overlie pre-Tertiary rocks exposed from 2 to $8 \mathrm{~km}$ to the north. The complex is unconformably overlain by the Dinner Creek Ash-Flow Tuff.

\section{LITHOLOGY}

In the Castle Rock area, the "unnamed Igneous complex" consists of dense, porphyritic, palagonitic and vesicular basalt flows with two interstratifled pillow palagonite breccias. These flows are simflar to those described by Haddock (1967). The lower $265 \mathrm{~m}$ of Haddock's reference section consists of massive aphanitic basalt flows and two extensive palagonitic breccias (Fig. 8). The Castle Rock section is similar, but contains five porphyritic basalt flows and some coarser grained flows not described by Haddock. The upper 116 m of Haddock's section contains scoriacious basalt flows and basaltic breccias, while the Castle Rock section is composed of dense aphanitic flows. 
The pillow palagonfte brecclas in the lower part of the Castle Rock section are composed of fine-grained and glassy basalt fragments with lesser amounts of crystalline basalt fragments. Palagonitic pillows of nonvesicular basalt are commonly rimmed by black glass. These plilows range in size from 0.15 to $0.3 \mathrm{~m}$ in thickness and from 0.2 to $3 \mathrm{~m}$ in length and are generally surrounded by palagonitic breccia. Zeolfte minerals, calcite and amorphous silica are present and welldeveloped foreset bedding indicate deposition from the southeast. The brecclas of Haddock's section are similar and calcite and stilbite fillings and linings are common in cavities, but no depositional structures or pillows were described.

All of the flows observed in the Castle Rock area appear in this section to be basalts, although more detailed work may conclude that some are basaltic andesites. These flows can be divided into two representative groups to aid in petrographic description; namely, porphyritic and aphanitic. The Castle Rock Section (App. A, Sec. 1) consists of over 25 individual flows with porphyritic flows comprising about one in five (Fig. 10). Most porphyritic flows lie stratigraphically below the upper pillow palagonite breccia (Unit No. 13). These are generally hypocrystalline, and commonly have an intergranular groundmass. Phenocrysts commonly compose 20 percent of these rocks with plagioclase and olivine being most common. Plagioclase laths measure up to $1 \mathrm{~cm}$ in length, comprising about 75 to 90 percent of the phenocrysts with 


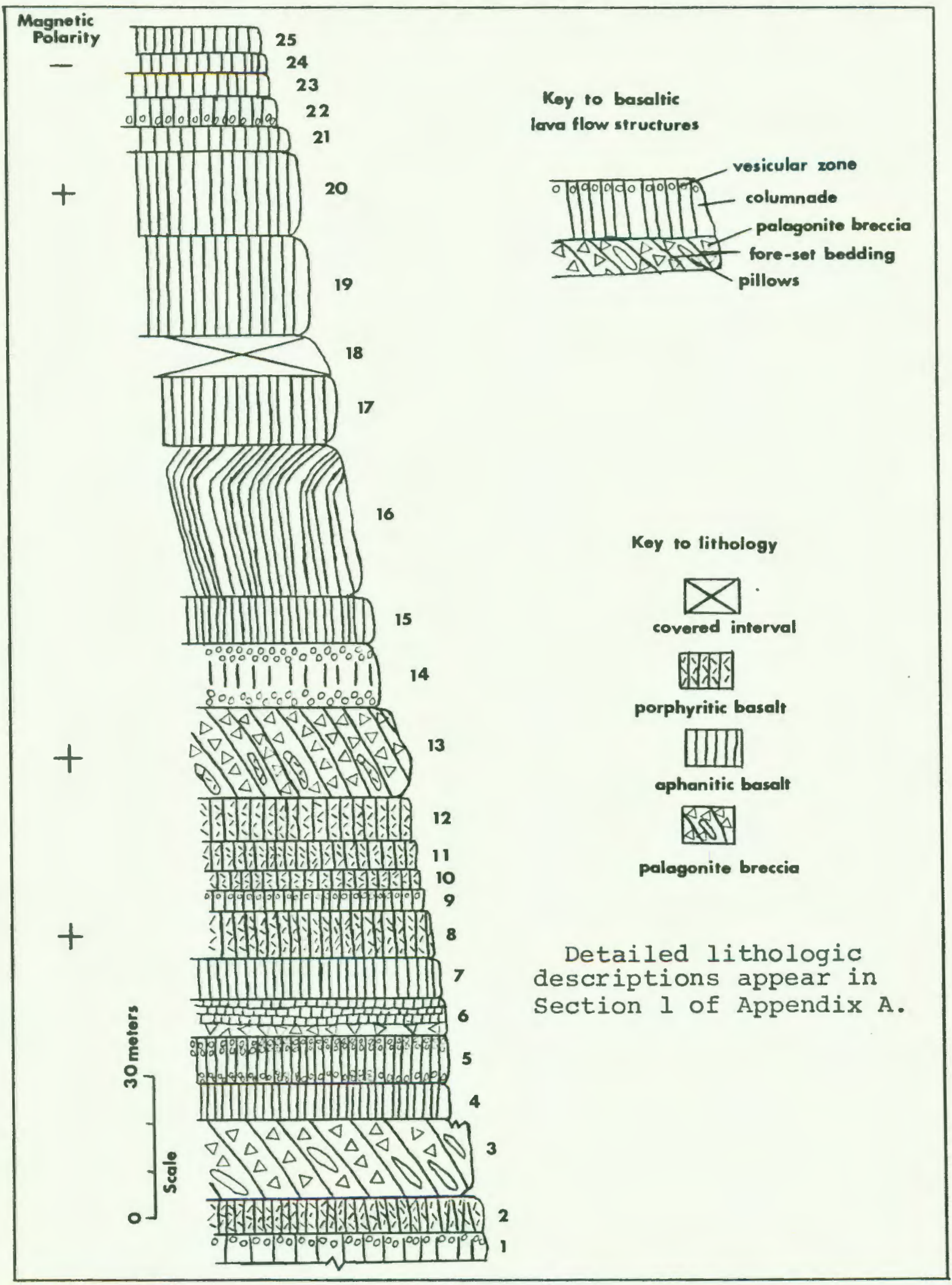

Figure 10. Measured stratigraphic section of the "unnamed igneous complex", at the south end of the Castle Rock ridge (secs. 15 \& 16, T. 18 S., R. 37 E.). 
olivine and pyroxene making up the rest. Plagloclase phenocrysts have good crystal outlines but are badly cracked and show strained extinction. Similarly, pyroxene crystals are commonly altered to a fibrous mineraloid with sector zoning suggestive of augite, although optical properties are indeterminable. Zeolite, calcite, and amorphous silica are common in these flows. Plagloclase in the groundmass was determined to be about An58-63 and composes about 30 percent of the rock. A dark glassy groundmass makes up about 40 percent of the rock and over 5 percent may be made up of secondary minerals and alteration products. Ferromagnesian minerals such as magnetite, olivine, and pyroxene occur within the angular intersticles between plagloclase laths in the groundmass. Modal compositions by Haddock (1967) are listed in Table 1, and their relative position within his section, and its relationship to the Castle Rock section is shown in Figure 8 .

Aphanitic basalt flows are the most common rock type found within the "unnamed igneous complex." Three dense basalt samples have an average silica content of $44.5( \pm 2)$ percent (APP. B, Table 2). Most commonly these are hypocrystalline and aphanitic, having intergranular to intersertal and sometimes subophitic textures with sparse phenocrysts. These flows are generally composed of about 40 to 50 percent plagloclase, 20 to 35 percent augite, 0 to 5 percent olivine, 5 to 10 percent opaque minerals, with the remainder being a fine matrix of glass, secondary minerals and alteration products. 
TABLE I

MODAL COMPOSITION OF BASALTS FROM THE "UNNAMED IGNEOUS COMPLEX" (FROM HADDOCK, 1967)

\begin{tabular}{|c|c|c|c|c|c|c|c|}
\hline $\begin{array}{l}\text { Specimen } \\
\text { number }\end{array}$ & $\begin{array}{c}\text { Plagioclase } \\
\text { An }\end{array}$ & $\begin{array}{c}\text { Subcalcic } \\
\text { Augite }\end{array}$ & Olivine & $\begin{array}{c}\text { Opaque } \\
\text { Minerals }\end{array}$ & Glass & $\begin{array}{l}\text { Alteration } \\
\text { products }\end{array}$ & $\begin{array}{l}\text { Points } \\
\text { Counted }\end{array}$ \\
\hline 10 & $46.0_{51-58}$ & 31.4 & Tr. & 7.5 & 11.0 & 4.1 & 750 \\
\hline 9 & $48.0_{52-60}$ & 29.8 & 0.3 & 9.2 & 8.7 & 4.0 & 750 \\
\hline 8 & $46 \cdot 1_{54}$ & 29.1 & 1.0 & 8.3 & 9.8 & 5.7 & 800 \\
\hline 7 & $48.7_{55-59}$ & 22.7 & $\operatorname{Tr}$. & 4.1 & 10.9 & 13.5 & 750 \\
\hline 6 & $5 I .9_{50-56}$ & 31.3 & 3.9 & 6.4 & 5.6 & 0.9 & 750 \\
\hline 5 & $48 \cdot 4_{55}$ & 32.5 & 0 & 7.7 & 3.2 & 7.6 & 750 \\
\hline 4 & $39.2_{52}$ & 28.1 & 0 & 6.5 & 17.1 & 9.1 & 750 \\
\hline 3 & $41.4_{56}$ & 34.8 & 0.2 & 5.3 & 6.5 & 12.7 & 850 \\
\hline 2 & $45.157-58$ & 22.9 & 0 & 3.3 & 9.6 & 18.6 & 750 \\
\hline 1 & $50 \cdot 6_{53-59}$ & 32.8 & 1.0 & 5.6 & 5.6 & 4.6 & 500 \\
\hline
\end{tabular}


AGE AND CORRELATION

The age of the "unnamed Igneous complex" was tentatively established as no younger than Late Mlocene by Kittleman and others (1965), who indicate that it is indirectly overlain by sediments containing Barstovian mamalian fossils. These Barstovian deposits, the Butte Creek Volcanic Sandstone, have been dated at $15.1 \mathrm{~m}$ y by potassium argon age determination (Evernden and others, 1964).

\section{Reglonally the "unnamed Igneous complex" is possibly} correlative with the Steens Basalt, Steens Mountain Volcanic Series, Owyhee Basalt and other lava complexes such as those of western Idaho, northern Oregon and southern Washington. These are very similar in age to the Columbia River Basalt, but their exact relationships are uncertain. In one of the earliest organized investigations, the "unnamed igneous complex" was Included In a super unit termed the "Basement Complex." Flows of the "unnamed igneous complex" are those below the welded ash-flow tuff (Dinner Creek) marker bed of the "Basement Complex." Similarly, flows of this complex were included in the "Strawberry Volcanics" as mapped by Brown and Thayer (1966) within the Castle Rock area.

In general, flows of the complex dip towards the northwest, causing older flows to be exposed farther to the southeast. Beaulieu (1972) believes that about $330 \mathrm{~m}$ of intercalated autoclastic brecclas and dense aphanitic basalts exposed in the Crowley area (Greene, 1962) represent the 
lower part of the section. The middle part of the section is probably represented by $200 \mathrm{~m}$ of porphyritic olivine basalt flows overlain by 230 m of platy aphanitic andesite and andesitic basalts exposed in the Monument Peak area (Hagood, 1963). The uppermost part of the section is probably represented by the porphyritic to aphanitic flows and breccias exposed in the Castle Rock area, Malheur Gorge area and the Central Monument Peak area, comprising a section more than $670 \mathrm{~m}$ in thickness. Correlation is complicated by the fact that continuous stratigraphic markers within the complex are absent. However, the porphyritic flows are more common in the lower part of the section and mark a general stratigraphic position. Simflar rocks, the Ring Butte andestee, as described by Lowry (1968) north of the Castle Rock area, may represent the base of the section. 


\section{DINNER CREEK WELDED ASH-FLOW TUFF}

\section{DEFINITION}

The Dinner Creek Welded Ash-Flow Tuff (Tdc) was named by Kittleman and others (1965, p. 18) for exposures on Dinner Creek, southwest of Jonesboro, at the type locality in the NW $1 / 4$ SE $1 / 4$ sec. 30, T. 21 S., R. 39 E. The Dinner Creek was described by Dole and Corcoran (1954) and was referred to as the welded tuff marker bed in the Malheur Gorge. Bowen (1956) and Gray (1956) described this unit, referring to it as the welded tuff member of the Owyhee Basalt, but it was not mapped as a separate unit. This designation was changed to welded tuff within the "Basement Complex" by Bowen and others (1963). Haddock (1967) provides the most complete description of the unit, describing textural, chemical and physical characteristics as well as interpreting flow directions and possible source areas. Lowry (1968) described this unit and also named possible source areas, although he referred to it and local rhyolite flows as Dooley Rhyolite.

\section{DISTRIBUTION AND THICKNESS}

The Dinner Creek Welded Ash-Flow Tuff is found in scattered exposures totalling about $8 \mathrm{~km}^{2}$ and $1 \mathrm{~s}$ as thick as $470 \mathrm{~m} \mathrm{locally.} \mathrm{The} 470 \mathrm{~m}$ section at Black Butte (sec. 24, T. 17 S., R. 36 E.) is probably excessive due to 1 ts plug- 
like nature. However, a section of almost $300 \mathrm{~m}$ is exposed in Jerry Canyon on the east side of the thesis area. From the Castle Rock area the tuff sheet extends over $65 \mathrm{~km}$ to southeast, where it thins to about $6 \mathrm{~m}$ (Haddock, 1967). An Isopach map by Haddock (1967) shows this tuff to have a total areal extent of at least $2,560 \mathrm{~km}^{2}$ and possibly as much as $5,000 \mathrm{~km}^{2}$. If the tuff has a uniform distribution away from Its source area its volume would be at least $80 \mathrm{~km}^{3}$ and possibly as much as $185 \mathrm{~km}^{3}$. The base, where exposed, overlies lava flows of the "unnamed Igneous complex" or a light gray pumice lapilli-tuff of about $20 \mathrm{~m}$ in thickness. The Dinner Creek Tuff is unconformably overlain by rocks of the Strawberry Volcanics and tuffaceous sediment of the Juntura Formation.

\section{GENERAL LITHOLOGY}

The Dinner Creek Welded Ash-Flow Tuff is a prominent marker bed around Castle Rock and adjacent areas. It is a densely welded sheet enclosed in an envelope of glassy and non-welded material. The densest welding took place in the center of the flow and decreased relatively uniformly towards the edges (Haddock, 1967). Within and near the vents the ash-flow nature of this flow might escape the most meticulous field investigator because of the high degree of welding, subsequent alteration and well-developed laminar viscous flow structures. 
A fresh hand specimen appears dark violet or lavender to dark reddish-gray and weathers to a distinctive purplishred. Away from vent areas the rock is finer grained and has a more reddish appearance. Less welded zones may be 11 ghtbrown, very light purple or even greenish and weather to shades of red-brown. Flow layering is very prominent on a small scale, layers are about $1 \mathrm{~mm}$ apart, and impart a very distinctive fracture cleavage which causes hand specimens to split into plates about $4 \mathrm{~mm}$ in thickness. The rock consists of 4 to 5 percent pumice fragments, 1 to 4 percent sanidine and potassium feldspar and up to 5 percent xenolithic fragments in a matrix of purplish-gray glass.

\section{ZONATION}

The Dinner Creek tuff is divisible into seven major zones of welding and may be composed of three cooling units (Fig. 11). The basal and upper cooling units are composed of non-welded pumice lapilli-tuff, while the central zone is densely welded and complexiy zoned. This central cooling unit is divisible into seven vertical zones of welding and causes the tuff to have several distinct outcrop patterns (Fig. 11). Within the Castle Rock area the exact relationship between these zones is not readily apparent because more than two zones are rarely exposed together.

At Castle Rock the base is a very irregular zone of $10 \mathrm{~cm}$ or more of black frothy to dense crystal rich glass 


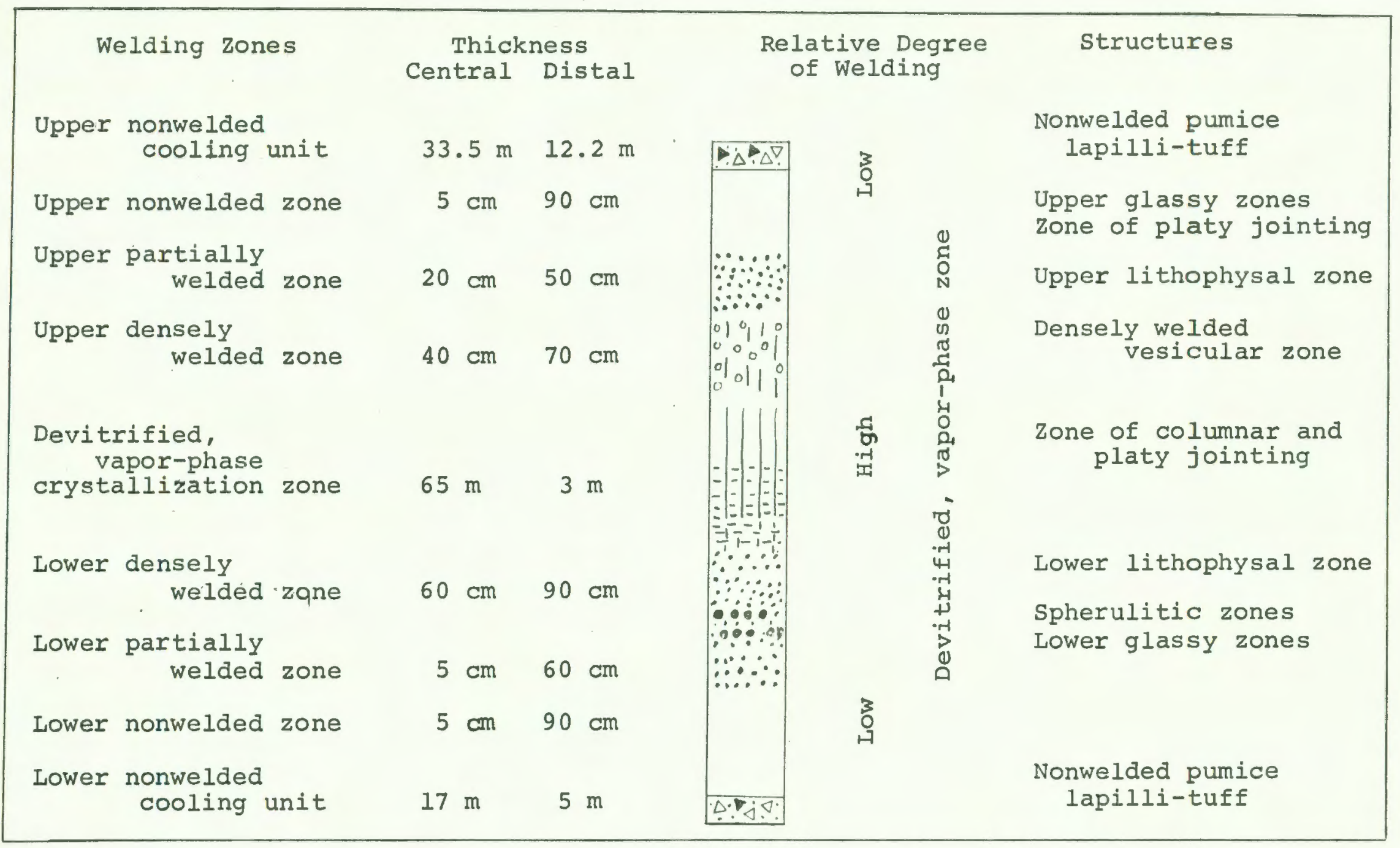

Figure 11. Lateral and vertical zonation within the Dinner Creek Welded Ash-Flow Tuff, a multiple flow compound cooling unit (after Haddock, 1967 ). 
resembling obsidian or pitchstone in places. This glassy chilled zone changes abruptly upward into densely welded darkbrown glassy tuff which in turn grades upward into the more characteristic grayish-red tuff. Elsewhere, the base Includes a non-welded zone of medium to light-gray pumice-lapilli-tuff which was mapped individually as a separate cooling unit and is only exposed in the mapped area southwest of Castle Rock (Sec. $20 \& 21$, T. $18 \mathrm{~S}$, R. 37 E.). The base in more distal areas has been described as non-welded ash which grades upward from light-gray non-welded tuff into dark-gray to black glass within a distance of 5 to $60 \mathrm{~cm}$ (Haddock, 1967). Cavernous weathering in the Castle Rock area may have resulted from the weathering out of a fine non-welded ash.

Above the non-welded and glassy zones is a densely welded devitrified zone resembling a purple-to-pinkish red rhyolite flow with phenocrysts of sanidine and small xenoliths. This devitrified zone consists of 30 percent or more vesicles, or vapor vugs, which may be over $6 \mathrm{~cm}$ in diameter, averaging about $2 \mathrm{~cm}$ in diameter. These vesicles decrease in size and number upward in the section. Much larger structures several meters in diameter show intricate wall and roof structures suggesting a primary orfgin, perhaps large vapor cavities or spiracles. Smaller vesicles are wholly or partially filled with white or bright blue secondary chalcedony. Zones of lithophysae and spherulites are common (FIg. 11). This zone grades upward into a zone of columar fointing with a 0.5 m joint spacing. Columnar jointing is commonly obscured 
by a well-developed platy fracture averaging 2 to $4 \mathrm{~mm}$ in thickness, oriented normal to the columnade. The columnar zone in turn grades upward into a lithophysal zone where lithophysae are uniform in size and comprise up to 50 percent of the rock. The lithophysae arefilled with secondary amorphous silfca but in distal regions have been described as being completely or partially filled with a spongy crystalline material of anorthoclase, tridymite, and crystobalite (Haddock, 1967).

The devitrified zone grades upward into a brownish red glassy zone of densely and finally lightly welded tuff. Above the upper glassy zones Haddock (1967) describes the remalns of an upper non-welded zone as a stratifled pumice-1apil11tuff and pumiceous sandstone rang1ng from 13 to $37 \mathrm{~m}$ in thickness. Within the Castle Rock area several units fitting this description are found above the Dinner Creek tuff. Some of these units are definitely much younger and others have a still uncertain relationship. This upper non-welded zone therefore could have been included with the pumiceous units In the Lost Creek Volcaniclastics which overlie the Dinner Creek Tuff locally.

\section{PETROGRAPHY}

A vitroclastic texture predominates throughout the welded tuff in both glassy and devitrified zones. An axiolithic texture consisting of flbrous minerals which have grown elongated along shard boundaries, and a eutaxitic 
structure around rims of lithophysae have been described in detall by previous investigators (Bowen, and others, 1963; and Haddock, 1967). Individual reddish colored glass shards compose about 95 percent of the rock in compact zones and show a wide degree of flattening and stretching. Flattening took place in the horizontal plane resulting from post-depositional setting and compaction of hot particles under the welght of overlying ash. Stretching was caused during actual flow and emplacement of the ash sheet, and is a linear feature oriented in the direction of movement. Haddock (1967) mentions that in and near the vent area at Castle Rock glass shards are extremely stretched and become decreasingly stretched away from the vent area. The numerous elongated vesicles and stretched glass. shards suggest post-depositional movement of the ash-flow sheet in many areas. Devitrification of this ash sheet is more pronounced in the center of the flow and in near vent areas.

Phenocrysts of anorthoclase, sanidine and oligoclase and quartz comprise up to 4 percent of the rock (Bowen and others, 1963; and Haddock, 1967). Anorthoclase and sanidine are by far the most abundant, comprising over 80 percent of the phenocrysts. The number of potassium feldspar crystals increases upward in the section and their once euhedral outlines are embayed. Amorphous silica of various colors commonly fills fractures and gas cavities within the rock. Magnetite constitutes less than 1 percent of the rock; 1 t 
occurs primarily as dusty anhedral grains and rarely as euhedral crystals. Dusty hematite may be responsible for the reddish color of the glassy matrix (Gray, 1956). Other minerals are zircon, clinopyroxene and a small number of quartz crystals having the dipyramidal hablt of beta quartz (Haddock, 1967).

Lithic fragments ranging from $0.1 \mathrm{~mm}$ to $6 \mathrm{~cm}$ in diameter Increase In abundance near the top of the tuff sheet and seldom comprise more than one percent of the total rock (F1g. 12). Pumlce and welded tuff fragments are much more abundant near the top of the section, while xenolithic forelgn material is more disseminated throughout the tuff sheet. Basaltic xenoliths are by far the most common. Xenoliths of flow-layered rhyolite, sandstone and possibly some altered shale have been reported (Haddock, 1967). Xenoliths show almost no reaction rims and may be accentuated by coarsergrained, lighter-colored tuff surrounding them. These xenoliths apparently acted in places as nucleation points for early crystallization of the tuff, belng most common in and near vents. Glass shards are commonly bent around 11 thic fragments and phenocrysts.

\section{SOURCE AREAS}

The most critical problem with extensive ash-flow deposits is the location and characteristics of their source areas, which are usually heavily burled by the sheets they 

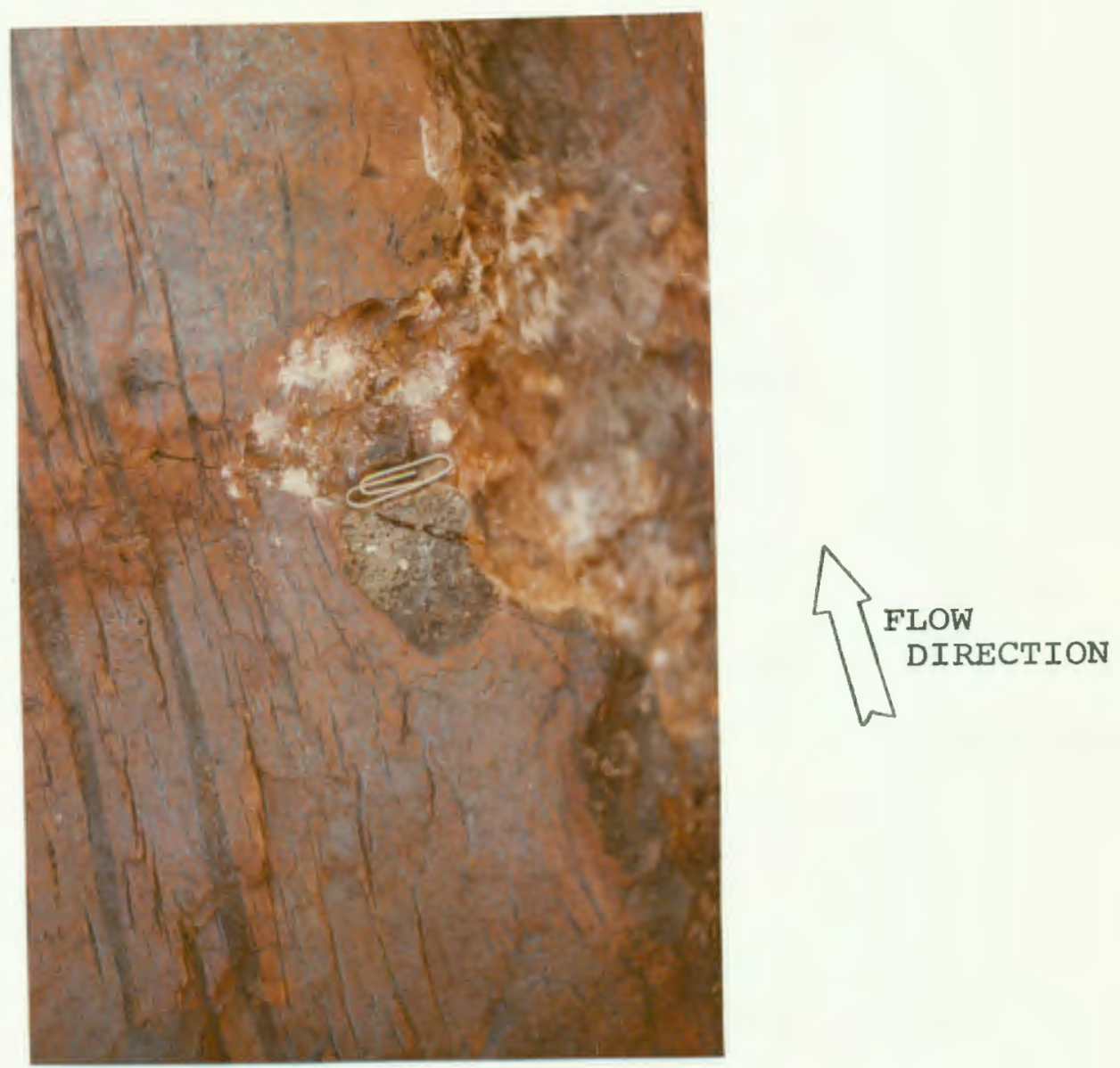

Figure 12. Basaltic xenolith and steeply inclined flow-layering in the southwest side of the Castle Rock dike ( $\mathrm{NE} \mathrm{1/4} \mathrm{SW} \mathrm{1/4} \mathrm{NW} \mathrm{1/4,} \mathrm{sec.} \mathrm{9,} \mathrm{T.} 18 \mathrm{~S}$, R. $37 \mathrm{E.}$ ). The xenolith is about $6 \mathrm{~cm}$ in length (paper clip indicates scale). Note hollow at upstream side of xenolith and arrow indicating flow direction. 
produce. In fact, very few intrusive ash-flow bodies have been recognized as sources for tuff sheets. The Castle Rock area and Ironside Mountain quadrangle to the north are unique In that dikes and central vents representing the southernmost extension of a north-south trending dike system are exposed. Intrusive Dinner Creek Tuff bodies within the Castle Rock area are represented by Black Butte, possibly a central vent and Castle Rock, a 2 km-1ong dike.

Features in the vicinity of the Castle Rock dike suggestive of its intrusive nature are its geometric outline and 1solated exposure (F1g. 13, Plate 1). Flow layering is steeply Inclined in the southern end of the Castle Rock dike, but dips an average of 37 degrees to the northwest at the northern end. Flow layering and a rude joint set within the dike appear to fan outward near the top of the dike (F1g.14). Jolnts have a $2 \mathrm{~m}$ spacing and surfaces are polished slikensided faces of light green to dark purple colored glass. Quartz-f1lled vesicles, highly elongated, vitric nodules and basaltic xenoliths are common within the dike. Brecciated flow remants and glassy tuff are found locally near the base of the dike.

The lower slopes of the Castle Rock ridge are composed of a thick sequence of basalt flows which dip about 20 degrees to the northwest (F1g. 13, Plate 1). Erosional remnants of brecclated flow material of the Dinner Creek Tuff are common on the basaltic slopes below the Castle Rock dike. 


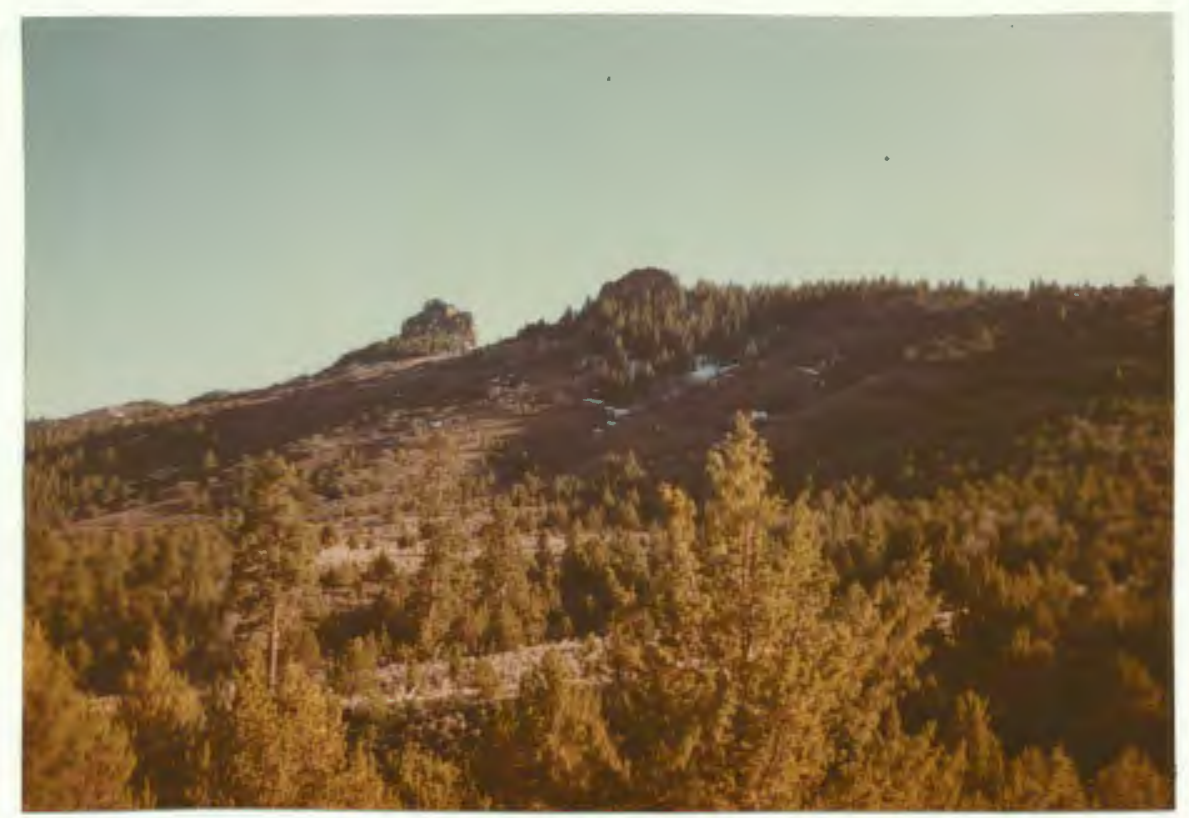

Figure 13. View of the $2 \mathrm{~km}$ long Castle Rock dike looking southwestward. Note the isolated exposure on top of the basaltic ridge (trees at base of dike indicate scale).

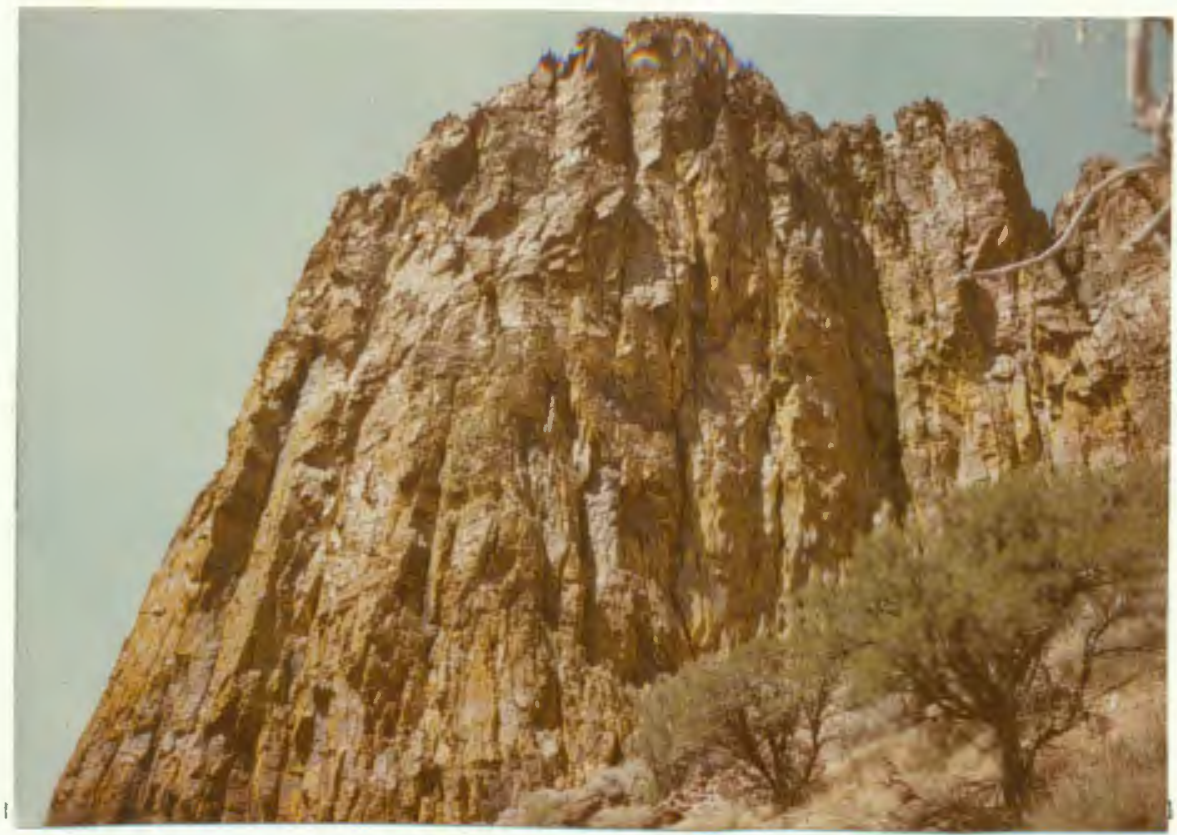

Figure 14. View of the south end of the Castle Rock dike. This exposure is more than $180 \mathrm{~m}$ in height with with a 2 m joint spacing. 
These rocks may represent autobrecciated flow material or hot avalanche deposits deficient in nonwelded ash size material. This breccia consists of large angular blocks rangIng In size from 0.5 to over $3 \mathrm{~m}$ In diameter, chaotically welded together. This brecclated Dinner Creek Tuff is believed confined to near-vent areas. Nowhere else were these large welded blocks found and Kittleman and others (1965), Haddock (1967) and Lowry (1968) described none in more distal parts of the flow. Ramping structures caused by viscous flowage are exposed in a canyon wall (SW $1 / 4$ NE $1 / 4$ SW $1 / 4$ of sec. 6, T. $18 \mathrm{~s}$, R. 37 E.) west of Castle Rock. These ramping structures appear as concentric joints with their convex sides facing away from the Castle Rock dike (FIg. 15). Ramping structures are excellent indicators of flow direction and two or more on the opposite sides of a vent may serve to locate it.

Flow-layering in the northern end of the Castle Rock dike dips in the direction of Black Butte, suggesting the two may be connected at a relatively shallow depth (FIg. 16). Attitudes on flow-layering and the relative geographic closeness of these two Intrusive features indicate they may be connected more shallow than subcrustal levels, but probably no shallower than 3000 to 4000 feet ( 100 to $1330 \mathrm{~m})$. A contact at the south end of Castle Rock indicates that the dike occupled a topographically high position at the time of extrusion and flows traveled over basalts of the "unnamed 


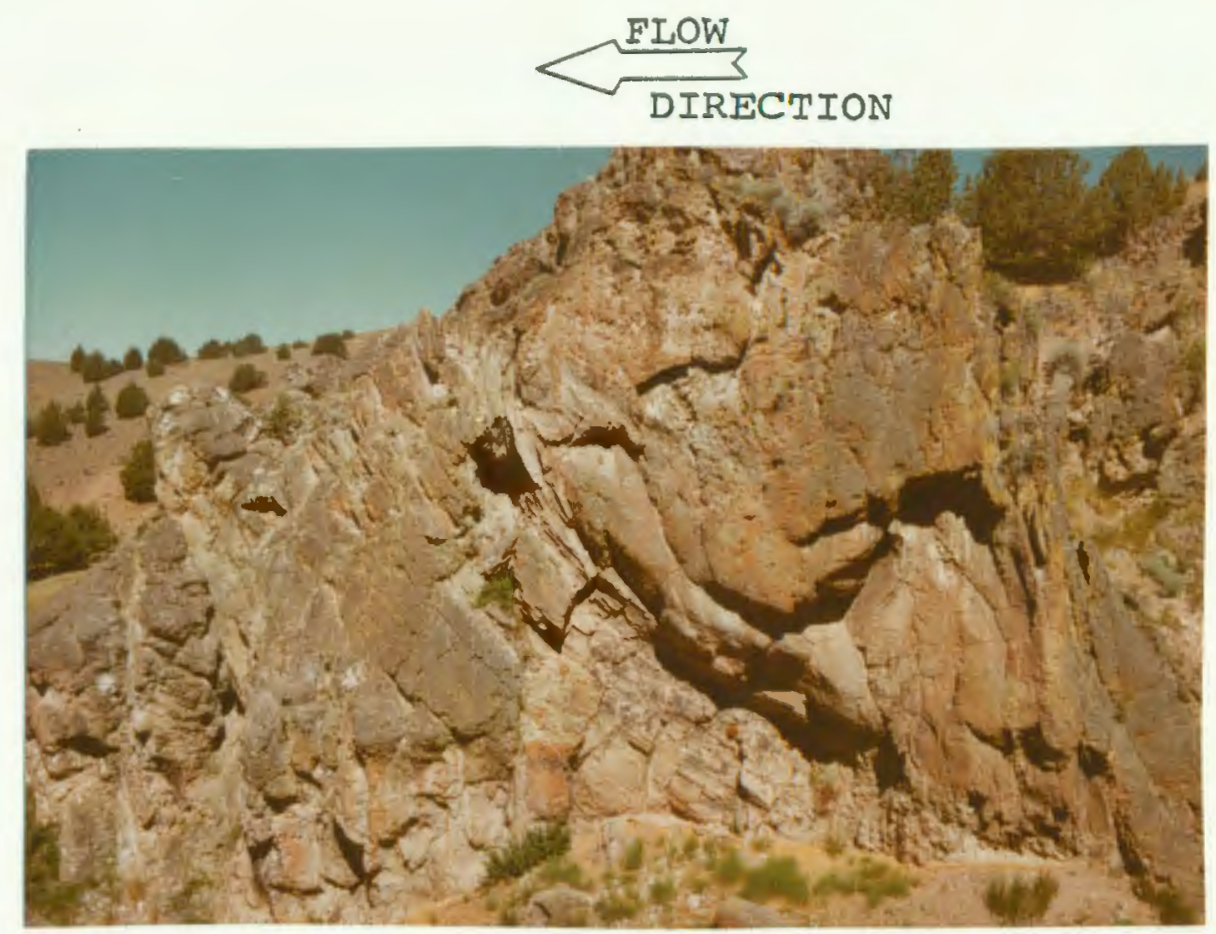

Figure 15. Ramping structures preserved within an erosional remnant of the Dinner Creek Tuff sheet ( $\mathrm{NE} 1 / 4 \mathrm{SW} 1 / 4 \mathrm{sec} .6, \mathrm{~T} .18 \mathrm{~S} ., \mathrm{R} .37 \mathrm{E}$. ). These structures are approximately $15 \mathrm{~m}$ tall. The direction of flowage was from right to left, away from the castle Rock dike. 
Diagramatic cross sections of the Castle Rock dike, indicating relative positions of near vent structures.

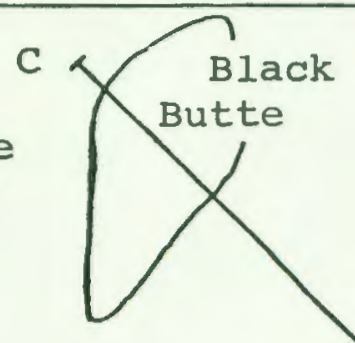

Map view of Castle Rock and Black Butte

A)

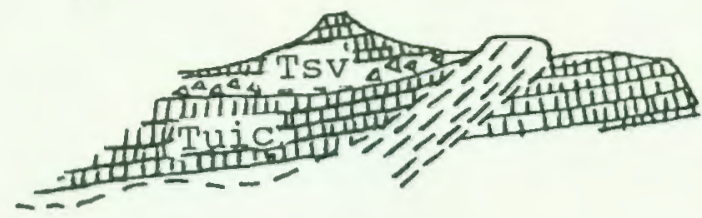

Cross section of the north end of the castle Rock dike. Flow layering is inclined 40 degrees.

B)

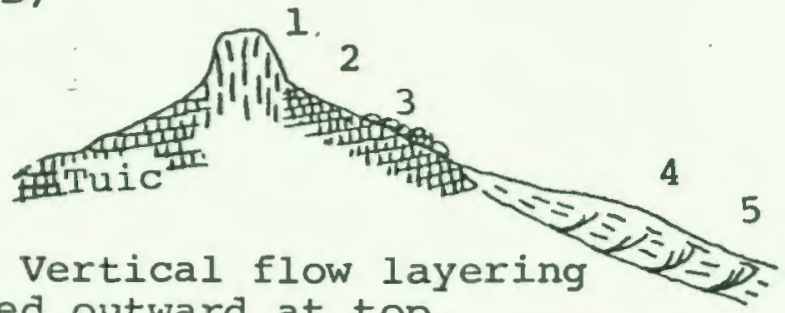
Castle Rock dike

$$
\text { scale }=1: 64,500
$$

nned outward at top.

2. Glassy welded tuff and breccia near contact.

3. Remnants of autobrecciated flows

4. Near horizontal flow layering and ramping structures within tuff sheet.

Cross section of the south end of the Castle Rock dike.

C

Cástle Rock Dike

6000 - Black Butte

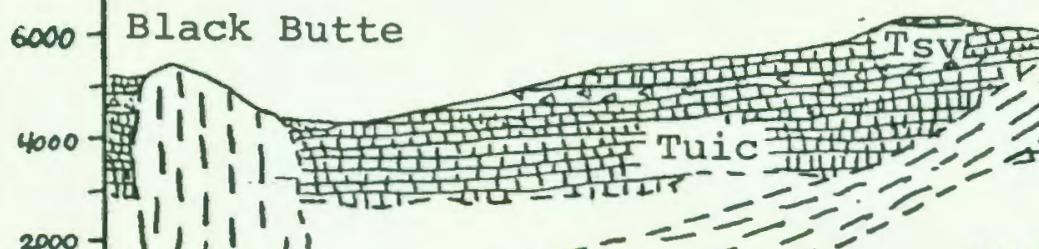

$2000-{ }_{1}^{1} 1111 ! 1, \ldots=$

$-1=-2=-2$

pre-Tertiary

(FEkT)

Cross section between Black Butte and Castle Rock indicating possible genetic relationship at depth.

Figure 16. Cross sections of the Castle Rock and Black Butte intrusions, showing the relative positions of flowage structures within the Dinner Creek Tuff sheet. 
45

Igneous complex" Into valleys on both sides of the ridge. These valleys are traceable by the thick accumulations of Dinner Creek Tuff which roughly parallel the present valleys, and have been eroded off on higher slopes, exposing the pareeruption paleotopography.

AGE AND CORRELATION

The Dinner Creek Welded Ash-Flow Tuff has been assigned an age of Late Miocene on the basis of Its stratigraphic position above the "unnamed Igneous complex" and below the Strawberry Volcanic and Juntura Formation. Radiometric ages of 14.3 to $14.9 \mathrm{~m}$ y have been reported for this unit (Walker and others, 1974). 


\section{STRAWBERRY VOLCANICS}

\section{DEFINITION}

The Strawberry Volcanics comprise a complex series of silicic to mafic lava flows more than $2,700 \mathrm{~m}$ in thickness (Thayer and Brown, 1973), first described by Thayer (1957) in the area of Strawberry Mountain $55 \mathrm{~km}$ northwest of Castle Rock. The actual unit as originally mapped includes many units which have since received formal naming, making the exact 11 thology and extent quite vague. Brown and Thayer (1966) Included all Late Miocene volcanic rocks of the Castle Rock area and the $30 \mathrm{~min}$. Ironside Mountain quadrangle to the north within this unit. Thayer and Brown (1973, P. 492-493) described a generalized section at Ironside Mountain, part of which is similar to the reference section of this report (App. A, Sec. 2). The Strawberry Volcanics are a significant regional stratigraphic unit and will be more precisely described and redefined in the future with accumulation of more information.

In the map area, Plate 1, the Strawberry Volcanics consist of interstratified lava flows and volcaniclastics which are subdivided into four members on a lithologic basis. The base of the Strawberry Volcanics is defined locally as a series of rhyolitic flows and brecclas (Tsvr), forming the lower member. This unit is in part correlative to the 
Littlefleld Rhyolite (Haddock, 1967). Stratigraphically above the rhyolitic lava flow and breccia member are a thick sequence of platy basaltic to dacitic lava flows (Tsv), which comprise the bulk of the formation. Interbedded with the basaltic to dacitic lava flow member is a volcaniclastic member ( $T s v v$ ) composed predominantly of pumice-lapil11-tuffs and minor sedimentary strata. Included within this volcaniclastic member is a pumice lapilli-tuff marker bed (Tsvm). Three relatively thin open-textured olivine basalts or basaltic andesite flows (Tsvb), forming the fourth member, overlie the volcaniclastic member and are interbedded with the basaltic to dacitic lava flow member high in the section. A reference section, including strata of all but the basal member, appears in Figure 17 and a detalled lithologic description of the formation is given in Appendix A, Section 2. Rocks of the strawberry Volcanics unconformably overlie the strata of the "unnamed Igneous complex" and Dinner Creek AshFlow Tuff and underlie strata of the Juntura Formation disconformably.

\section{DISTRIBUTION AND THICKNESS}

The rhyolitic lava flow and breccla member (Tsvr) covers an area of less than $0.5 \mathrm{~km}^{2}$ and has a maximum thickness of $80 \mathrm{~m}$. This unit is exposed primarily along the east wall of Jerry Canyon and $2 \mathrm{~km}$ southeast of the Castle Rock Ranch.

The basaltic to dacitic lava flow member (Tsv) covers 
an area exceeding $15 \mathrm{~km}^{2}$ and $1 \mathrm{~s}$ more than $150 \mathrm{~m}$ thick. This member is thickest in the northern half of the Castle Rock area.

The volcaniclastic member (Tsvv) is exposed over an area of $12 \mathrm{~km}^{2}$ and probably underlies an additional $36 \mathrm{~km}^{2}$ of the thesis area. These strata have a thickness exceedIng 200 m but tend to thin away from Lost creek east of Black Butte. These beds have been described $30 \mathrm{~km}$ to the north (Lowry, 1968) and have a minimum regional distribution of about $1,600 \mathrm{~km}^{2}$.

The upper open-textured basalt member (Tsvb) is exposed in scattered outcrops throughout the northern half of the Castle Rock area. These lava flows have a maximum thickness of $55 \mathrm{~m}$.

\section{LITHOLOGY}

\section{Rhyolitic Lava Flow and Breccla Member}

A rhyolitic breccia, at the base of the formation, exposed In the southeast wall of Jerry Canyon, was mapped as Littlefield Rhyolite by Haddock (1967), Indicating the two are correlative. This breccia is over 30 m thick and is closely assoclated with a dense dark-gray to black, finegrained, silicic lava flow about $22 \mathrm{~m}$ thick, which apparently grades into the breccla. The breccla consists of large lava blocks over 2 m square to small angular fragments chaotically embedded In a fine, dark-brown to light-red sandy 
matrix and commonly weathers into hoodoos or spires. The exact origin of the breccia is uncertain, but its association with a lithologically similar lava flow suggests subaqueous brecciation. Ramping structures indicate that the flow came from the north and entered a small lake. The flow may have had a sublacustrine or igin, but lack of sedimentary material and abundant coarse angular fragments suggests a near vent source.

A terrestrial rhyolite breccla about $10 \mathrm{~m}$ thick is exposed southwest of Horse Flat (Plate 1). This breccla is light-red to pale orange in color with autobrecclated fragments embedded In a fine, welded vitric matrix. The breccla is generally light in color and shows distinctive red, gray, and yellow crenulated flow layering. The rock is composed of about 95 percent glass with 3 percent anhedral magnetite, minor pyroxene and feldspar crystal fragments, and has a silica content of 73 percent (App. B).

\section{Basaltic to Dacitic Lava Flow Member}

The lava flows of this member have such a similar outcrop appearance and are so intimately interstratified that further subdivision on the basis of composition was not justifled. In general, the older flows are silicic and younger flows are basaltic. Many of the silicic flows are older than rocks of the reference section and are closely related to the rhyolitic breccias.

Silfcic flows are very fine-grained, medium to darkgray in color, although some are shades of light-brown. 
Dark flows commonly have a green mineral banding and a fine platy jointing. This jointing is commonly undulating in outcrop and develops along incipient flow layering. In hand specimen these rocks weather 11 ght-brown in color and feldspar and pyroxene crystals are visible on a fresh surface. other flows are highly scorlaceous with a coating of green alteration minerals. One flow with a $3 \mathrm{~m}$ thlck autobrecciated zone at the top, pink glassy streaks, green mineral bandIng, a very glassy groundmass and numerous flow structures common to rhyolites, has a silica content of less than $53( \pm 2)$ percent. A much coarser grained, less siliclc looking lava flow at the northwest end of Beulah Reservoir has a silica content of $64( \pm 2)$ percent (App. B, Table 2). Basaltic lava flows are characteristically dark-gray to black, very fine-grained with platy jointing and greenish streaks of alteration minerals between flow laminations. These flows are hypocrystalline and microporphyritic, with Intensely altered plagioclase and pyroxene phenocrysts about $1 \mathrm{~mm}$ in length. Fine plagioclase crystals, crystallites and microlites compose about 70 percent of the rock and are so we 11 aligned and curved around larger crystals as to resemble glass shards in an ash-flow. About 2 percent of this rock is composed of phenocrysts at a ratio of about 4 plagioclase to one pyroxene. A very dark glass matrix forms 20 percent of the rock and dusty magnetite makes up almost 5 percent. Silica contents on these basaltic rocks range from 41.0 to $52.5( \pm 2)$ percent. These flows average about $15 \mathrm{~m}$ in thick- 
ness, have very platy jointing but lack the viscous flow structures common to the older rhyolitic and dactic flows. Platy folnting in younger flows is developed along flow layers which most commonly parallel the basal contact of the flow. Several flows, however, have highly undulating wavelike viscous flow structures (F1g. 18, Plates A and B). The extremely tight folds developed in some platy lavas may have resulted from lava being extruded at a slow rate and flowed across a broad, relatively flat, gently sloping plafn. Another common structure is concentric jofnting enclosed within a poorly developed vertical joint set (F1g. 18, Plate C). These structures may have formed within a cylinder of lava within the flow.

\section{Volcaniclastic Member}

The volcanfclastic member of the Strawberry Volcanics consists of more than 20 I1thologically similar pumfce lap1111 tuff beds, one yellowish-brown volcanic conglomerate and two light-gray to brown ash beds (Fig. 17). The pumiceous tuffs are generally dull colored in shades of light-gray and brown and range in thickness from less than $2 \mathrm{~m}$ to more than $50 \mathrm{~m}$. Fragments consist lärgely of flattened pumice lap1111 and lesser amounts of lithic fragments as much as $15 \mathrm{~cm}$ long. Lithic fragments compose 5 to 10 percent of the rock, an ash matrix 30 to 70 percent, and pumice lap 111 make up the rest. Other constituents include minor amounts of plagfoclase, augite and hornblende crystals (Lowry, 1968). 


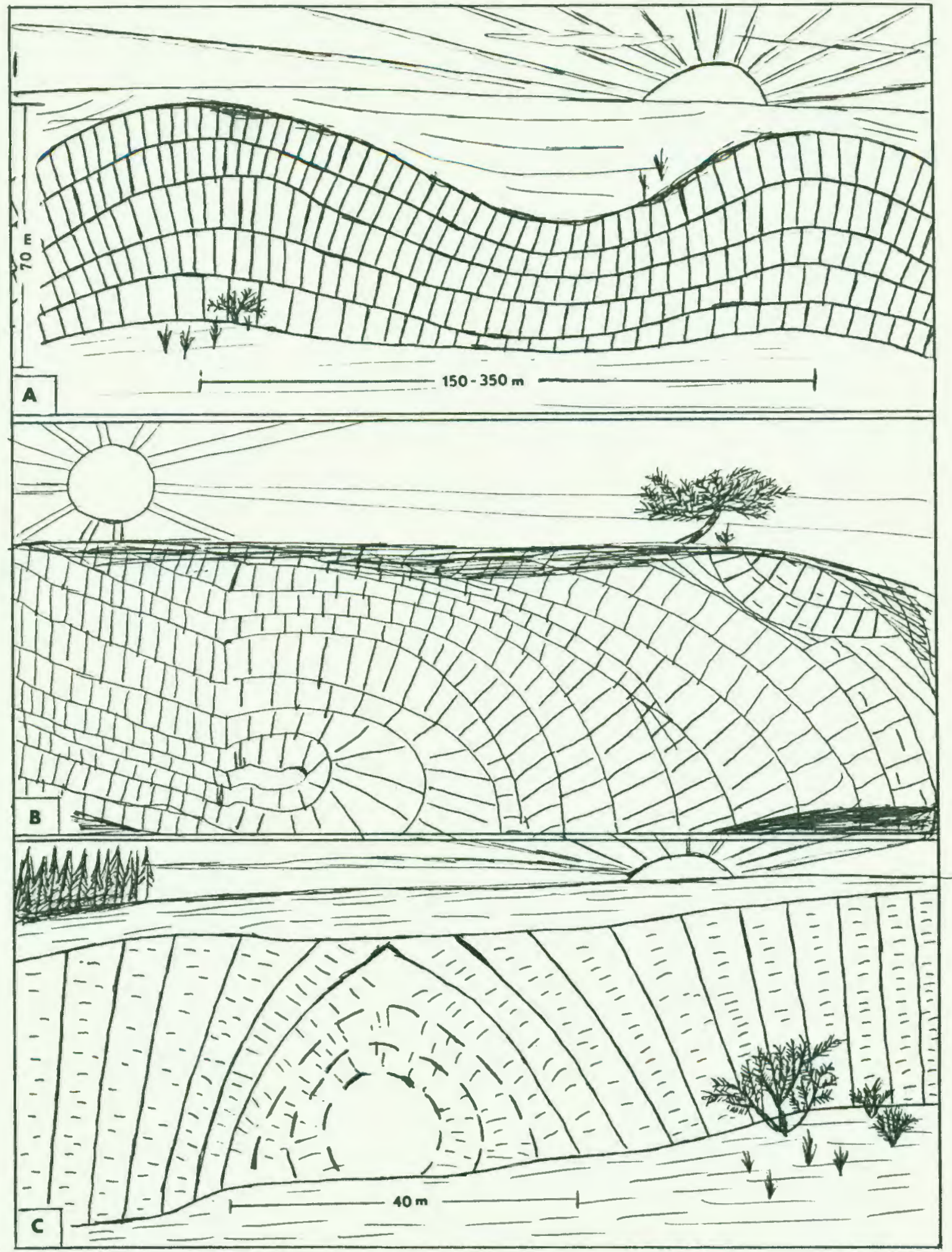

Figure 18. Jointing in lava flows of the strawberry. Volcanics (see text for discussion). 
Lowry (1968) measured the refractive Indicies of glass fragments of three tuffs as ranging from 1.482 to $1.506\left(\mathrm{~S}_{10}=72\right.$ to 68 percent; APP. B), indicating that these rocks are rhyolitic to dacitic in composition. A pumice lapilit-tuff marker bed (Tsvm) (UnIt 9, App. A, Sec. 2) was mapped separately to ald in determining the relative position of other tuffs within the stratigraphic section. Deposits of this unft are characteristically lense-shaped where they have filled shallow basins. Lava flows occur both above and below as well as interstratified with this unit.

The tuffs range from nonwelded to partially welded. Angular fragments and a lack of bedding rule out appreciable reworking by sedimentary processes. The distribution and thickness of some units suggest possible source areas near Goodwin's Tomb. The marker bed may have been derived from the area near the road Intersection $1 \mathrm{~km}$ south of the Castle Rock Fire Guard Station (W $1 / 4$ sec. 33 T. 17 S. R. 37 E.). In this area the marker bed contains dense fragments of Dinner Creek Ash-Flow Tuff, more than $8 \mathrm{~cm}$ long, which are not found elsewhere within the tuff sheet and probably could not have traveled far from the source area. Lowry (1968, p. 42) describes the remnant of a central volcano or vent related to these tuffs on the east slde of Rail Creek (NW $1 / 4 \mathrm{SW} 1 / 4 \mathrm{sec} .14, \mathrm{~T} .16 \mathrm{~S} ., \mathrm{R} .38 \mathrm{E}$.$) at an elevation of$ $1,750 \mathrm{~m}$ ( 5200 feet), north of the Castle Rock area.

\section{Olivine Basalt Member}

Three of the youngest flows of the strawberry Volcanics 
are medium-gray, medium to fine-gralned, diktytaxitic, porphyritic olivine basalt flows averaging $8 \mathrm{~m}$ in thickness (App. A, Sec. 2). Plagioclase and olivine are clearly v1sible in hand specimen. These rocks have dominant intergranular and subophitic textures, although an ophitic texture is found sporadically, and contain about 50 percent plagioclase $\left(\operatorname{An}_{58}\right), 10$ percent olivine, 18 percent augite, 2 percent opaque minerals and about 20 percent vesicles.

\section{AGE AND CORREATION}

No vertebrate fossils have been found within strata assigned to the Strawberry Volcanics. Lowry (1968) found fossil leaves and fronds but they were of an unidentifiable age. The Strawberry Volcanics are assigned herein, an age of very Late Miocene on the basis of stratigraphic position above the Late Miocene Dinner Creek Ash-Flow Tuff (14.3 m y; Walker and others, 1974) and below the Late Mlocene to Early P11ocene Juntura Formation (12.1 m $y$; Evernden and James, 1964). The older rhyolitic flows at the base of the strawberry Volcanics are considered equivalent to the Littlefield Rhyolite of Kittleman and others (1965) and Haddock (1967). 


\section{JUNTURA FORMATION}

\section{DEFINITION}

The Juntura Formation was named by Shotwell (Gray, 1956) and was first described by Bowen (1956) and Gray (1956). The Juntura Formation was formally named by Bowen, Gray and Gregory (1963) In the region south and southwest of the Castle Rock area. The type section has three parts: an upper member at a quarry $5 \mathrm{~km}$ south of Pete's Mountain, the middle member at Juniper Hill, and the lower member north of Scab Mountain (McClelian Mountain). Strata of the Juntura Formation disconformably overlie rocks of the strawberry volcanics and are overlain by the basal crystal rich tuff of the Drewsey Formation with minor disconformity.

\section{DISTRIBUTION AND THICKNESS}

The Juntura Formation covers approximately $16 \mathrm{~km}^{2} \mathrm{in}$ the southern half of the thesis area, has a minimal stratigraphic thickness of about $150 \mathrm{~m}$ and may be over $300 \mathrm{~m}$ thick In the southeastern part of the mapped area. Reglonally this formation is exposed over an area of at least $300 \mathrm{~km}^{2}$ and has a combined thickness of about 420 m (Bowen and others, 1963).

\section{THOLOGY}

The Juntura Formation, in the south and southwest parts 
of the Castle Rock area, consists of well-bedded lacustrine sediments. These strata include volcanic sandstones, tuffaceous clayey beds, water-laid tuffs, minor diatomite and interbedded ash. Thin palagonitic basalt flows, at least two and as many as five, are interbedded in the sediments throughout the area. Strata are generally light in color, poorly consolidated, but well stratified, showing many sedimentary structures.

Sedimentary strata

The oldest strata in this area are light-brown to yellow clay-stones. Manganese dioxide staining along bedding planes gives this rock a deceptive dark-brown to black appearance. These beds may be over $100 \mathrm{~m}$ in thickness and, where not capped by more resistant strata, weather into large, round hills with a characteristic covering of loose, clayey "popcorn" sol1 (F1g. 19).

Above these lacustrine strata ls a relatively thin but widely distributed volcanic sandstone bed. This sandstone unit is about $5 \mathrm{~m}$ in thickness and is generally fine-grained, light-greenish gray in color, well sorted with well-developed cross-bedding. Jofnts parallel bedding planes locally and solution of some parts has formed cavities within the rock. Stratigraphically above the sandstone bed is about $20 \mathrm{~m}$ of more indurated or we11-compacted, 11ght-brown to greenish, tuffaceous, clayey lacustrine sediments which have a wel1developed thin bedding. 


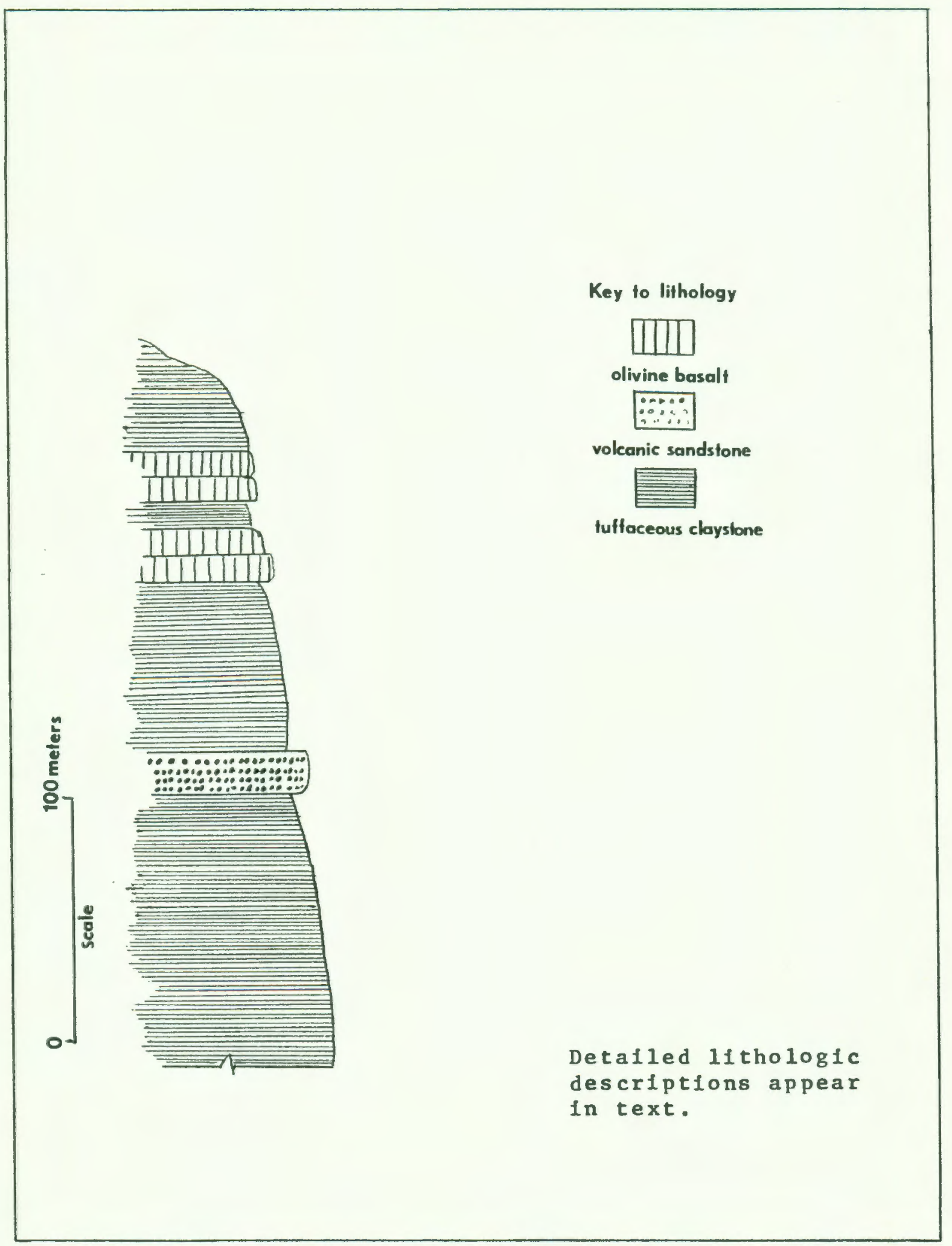

Figure 19. Composite stratigraphic section of the sedimentary strata of the Juntura Formation (measured in the $\mathrm{SW} 1 / 4 \mathrm{sec}$. 28, T. 18 S., R. 37 E.). 
Volcanic Strata

From two to five olivine basalt flows, totaling over $40 \mathrm{~m}$ in thickness where all are present, are exposed above the lacustrine strata. A light-colored claystone interbed separates the lower two flows from the others. This interbed increases in thickness towards the south, probably away from the margin of the depositional basin. Near Horse Flat these basalts have a flow-on-flow relationship. The basalts are fine to medium-grained, dark-gray to black with olivine phenocrysts. In thin section the basalt is hypocrystalline with intergranular textures. The rock consists of about 60 percent plagioclase, 10 percent olivine, 5 percent magnatite, minor amounts of altered augite and 15 percent brownish opaque mineraloid alterations products.

In the north and northeastern parts of the area the formation is more volcanic than sedimentary in nature. In Jerry Canyon light colored pumice lapili-tuffs and related fluviatile sedimentary lenses are the dominant lithologic types (Figs. 20 and 21). These strata are commonly 1 ight shades of green, brown, gray or white and are composed predominantly of pumiceous air-fall tuffs and minor conglomerates (App.A, Sec. 3). A lithologic comparison of the Juntura Formation within the Castle Rock area with that of the neighboring Juntura Basin shows considerable variation. Deposition of this formation in the Castle Rock area (the northern extremity of the Beulah Basin), while contemporaneous with deposition in the Juntura Basin, shows variations 


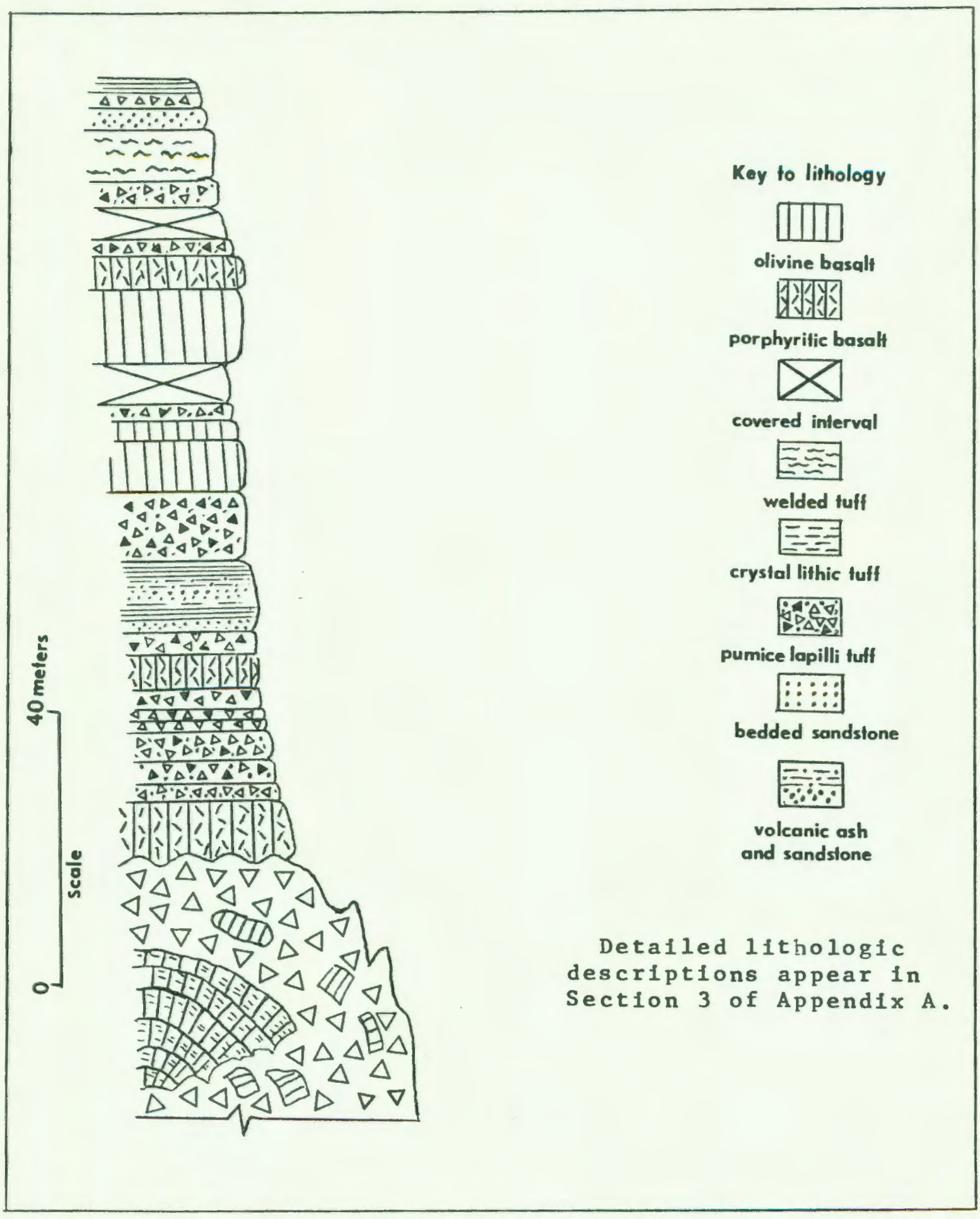

Figure 21. Measured stratigraphic section of the volcanic strata of the Juntura Formation at the southeast end of Jerry Canyon (SW $1 / 4 \mathrm{sec} .23$, T. 18 S., R. 37 E.). 
in both lithology and volume.

$$
\text { AGE AND CORRELATION }
$$

Fosstl leaves of Late Miocene age have been found near Beulah, Oregon (Russe1l, 1903). Fossils reflecting a shallow water lacustrine depositional environment, namely, fresh water mollusks, turtles and fish, as well as mammalian fossils in tuffaceous clayey beds, have been described (Gray, 1956).

The lower part of the Juntura Formation is believed to be Barstovian (Late Mlocene) in age and the upper part has been dated as clarendonian (Early Pliocene) by mamalian chronology (Shotwell and Russell, 1963, p. 43). Bowen and others (1963) indicate that fossil mamals from the Poison Creek Formation of Idaho, Deer Butte Formation in eastern Oregon, The Dalles Formation in north central oregon, and the Truckee Formation in Nevada, are all correlatives with the upper part of the Juntura Formation. Similarly, the Danforth Formation is correlative to the middle part of the Juntura Formation (Bowen and others, 1963). The Bully Creek Formation and the TIm's Peak sedimentary and volcanic unit, as described by Haddock (1967), correlates with the upper and lower members of the Juntura Formation, respectively. Floras and faunas from the Mascall Formation, Sucker Creek Formation, "Skull Springs beds," and the "beds at Beatty Butte" Indicate that these beds are roughly correlative with the lower member of the Juntura Formation (Chaney, 1959; Downs, 1956). 


\section{DREWSEY FORMATION}

\section{DEFINITION}

Strata of the Drewsey Formation were first described by Bowen (1956) and Gray (1956) and the formation was formally named by Bowen, Gray and Gregory (1963), who deslgnated exposures near Table Mountain north of the town of Drewsey along Mule Creek as the type section. Haddock (1967) mapped the basal crystal-rich ash-flow tuff of this formation north and east of Juntura, oregon. Strata of the Drewsey Formation are the youngest within the Castle Rock area and overlie the Juntura Formation with minor disconformity.

\section{DISTRIBUTION AND THICKNESS}

The ash-flow tuff which forms the base of the Drewsey Formation is exposed over an area of about $4 \mathrm{~km}^{2}$ within the Castle Rock area and has an average thickness of about $4 \mathrm{~m}$. The upper sedimentary unit may measure up to $50 \mathrm{~m}$ in thickness, but exists predominantiy as erosional remnants above the ash-flow. This formation has a regional extent of at least $250 \mathrm{~km}^{2}$ and a thickness in excess of $300 \mathrm{~m}$ (Bowen and others, 1963). The more extensive ash-flow sheet may have covered an area of over $11,500 \mathrm{~km}^{2}$, averaging $12 \mathrm{~m}$ in thickness and reaching a total volume of almost $65 \mathrm{~km}^{3}$ (Greene, 1973). 


\section{STRATIGRAPHY}

No well-defined stratigraphic break between the Drewsey Formation and the Juntura Formation is found in the Castle Rock area. For this reason, beds of the Drewsey Formation were mapped in this report on the basis of their stratigraphic position above the rhyolitic ash-flow which forms the base of the section. With the exception of scattered erosional remnants, exposures of the Drewsey Formation are linfted to the southeast part of the Castle Rock area along the North Fork of the Malheur River between the elevations of $1200 \mathrm{~m}(3,600$ feet $)$ and $1330 \mathrm{~m}(4,000$ feet $)$.

Only the basal rhyolitic welded ash-flow tuff member of the Drewsey Formation is well exposed in the thesis area. This tuff is very resistant to erosion and commonly forms a steep ledge which protrudes from the incompetent sediments surrounding it. The Drewsey welded tuff ranges from $11 \mathrm{ght}$ greenish to olive-gray in color, is generally compact with a densely welded central zone surrounded by a thin envelope of lightly welded ash, displays flattening of glass shards and pumice fragments and has a prominent platy jointing. In thin section this rhyolitic tuff has a vitroclastic texture and is composed of 80 to 90 percent glass shards, 8-12 percent flattened 11 thic and pumice fragments, 6-8 percent quartz crystals, 3-5 percent feldspar crystals and minor amounts of magnetite and augite.

The strata above this bed are heavily mantled by talus 
and vegetation. These beds are similar lithologically to the strata of the Juntura Formation exposed directly below the flow. Rocks above the ash-flow are predominantly lightbrown clayey tuffaceous sediments. These sediments weather very readily and characterlstically form very poor outcrops.

\section{AGE AND CORRELATION}

The welded tuff of the Drewsey Formation has been radiometrically dated at $9.2 \pm 0.6$ million years in age (Greene, 1973). The Drewsey Formation has produced HemphiIlian mammalian fauna, which indicates that 1 t may be correlative with the Rattlesnake Formation of the John Day Basin to the northwest (Bowen and others, 1963). Perhaps for this reason, Lowry ( 1968 ) mapped the Drewsey welded tuff as Rattlesnake Tuff even though he recognized the major lithologic difference and minor stratigraphic difference. Bowen and others (1963) suggest that the similarity of the sequence of lithologies in the Drewsey Formation suggests that 1 t may also be correlative with the upper part of the Danforth Formation in the Harney Basin to the southwest. It is believed by the author that the Drewsey tuff, the crystal-rich tuff of the Danforth Formation and the Devine Canyon tuff, as described by Greene (1963), are not only correlative in age, but all may be parts of the same eruptive phase. 
PLIOCENE TUFF PROBLEM

Haddock (1967) mentions that there are a number of welded ash-flow tuffs which could easily be mistaken for the Drewsey welded tuff, which occur in isolated areas of low relief at elevations between $1,400 \mathrm{~m}(4,200$ feet $)$ and $1670 \mathrm{~m}$ $(5,000$ feet $)$. In some areas these tuffs may be the Drewsey tuff, but in several areas they definitely are not. Haddock (1967) described one such tuff capping a hill one mile east of Juntura as having a modal composition of 94 percent devitrified glass shards, 4 percent sanidine, and 2 percent lithic fragments. The absence of quartz phenocrysts was used to distinguish it from the Drevsey tuff.

Lowry (1968) described a welded tuff in the upper Bendire Creek area which contains abundant crystals of potash feldspar. The section he described thickens towards the southeast corner of the Ironside Mountain 30-minute quadrangle and may be thicker than 65 m locally. Lowry attributes the greater thickness and greater degree of welding to the proximity to its source area, about $1 \mathrm{~km}$ east of the quadrangle along and north of the old Central oregon Highway, between the old Hunter (Wilson) Ranch and the town of Westfall (Lowry, 1968). Near the source area pleces of flattened pumlce over $30 \mathrm{~cm}$ in length were described within larger blocks of dark-gray welded tuff. Phenocrysts of potash feldspar and a perlitic groundmass serve to distinguish this from Drewsey tuff. This perlitic welded tuff is similar to that 
which occurs in Pliocene lake beds in the first cliffs west of Juntura on the north side of U. S. Highway 20, a unit mapped as Drewsey welded tuff by Bowen and others (1963) and Lowry (1968). Bowen and others (1963) mentioned the lack of plagloclase phenocrysts as characteristic of the Drewsey welded tuff except in inclusions. However, a few plagioclase phenocrysts were seen in thin sections of the Devine Canyon tuff, as mapped by Greene, Walker, and Corcoran (1972) in the northern portion of sec. 26, T. 18 S., R. 34 E. other than these few phenocrysts, the rocks are nearly Identical. Greene's (1973, P. 5 and 6) extensive study of the Devine Canyon welded tuff infers that it is part of the same ashflow which formed the Drewsey welded tuff. The Drewsey (Devine Canyon) tuff sheet may be a multiple flow compound cooling unit derived from scattered vents between Castle Rock and the town of Burns, Oregon. Haddock (1967) mentions that welded tuffs very similar in lithologic characteristics and stratigraphic position occur as far north as silvies Basin. Greene (1963) mentions that the variation in alkall feldspar and quartz phenocrysts is the outstanding feature of the welded tuff. Alkall feldspar phenocrysts are described as ranging from 1 to 29 percent, increasing stratigraphically upward within the flow and decreasing dramatically away from the source area. This variation has been used to recognize other similar crystal-rich tuffs, but more gophisticated methods such as trace element analyses may delineate other tuff sheets. However, no one has attempted to differentiate 
68

between these tuff or determine how many there init be. In the future, with accumulation of more data, the close lithologic and stratigraphic similarities and extreme lateral and vertical variations within the individual flows w111 be better understood, and discrimination of Individual flows a less difficult task. 


\section{SURFICIAL DEPOSITS}

\section{ALLUVIAL FAN DEPOSITS}

Alluvial fan deposits consist of unsorted or poorly sorted mixtures of gravel, sand and colluvium which accumulated in times of heavy runoff. The best developed fans are along the western side of the North Fork of the Malheur River Valley where small intermittent streams abruptly lose their gradlent upon entering the flat alluvial valley. These fan deposits have caused the river's position to shift eastward and undercut the pediments (secs. 13, 18, \& 19, T. 18 S., R. 37 E.). An older (posstbly Pleistocene) alluvial fan formed when this river was at a level graded to the upper pediment surface southeast of Horse Flat.

\section{LANDSLIDE DEPOSITS}

Scarps caused by faulting and oversteepened slopes along water courses are responsible for landsliding within the Castle Rock area. A very prominent rotational landslide block has moved downslope on the west side of the Castle Rock ridge, disturbing an area exceeding $1 \mathrm{~km}^{2}$ (F1gs. 22 and 23). The head of the landslide characteristically has an arcuate scarp above a flat bench which dips back into the hillside. The toe of the slide is marked by hummocky terrain with many springs and undrained depressions. The upper pillow pala- 
Formation as well as the Strawberry Volcanics are equally affected structurally. Most structural deformation appears to have occurred after deposition of the Juntura Formation. Emplacement of the Dinner Creek dikes along northtrending fissures caused local faults adjacent to volcanic centers. Subsidence at Black Butte is marked by volcanic strata dipping Inward as steeply as 18 degrees within an area of $5 \mathrm{~km}$ radius. Black Butte may have subsided as much as $2 \mathrm{~km}$ relative to Castle Rock. 


\section{GEOLOGIC HISTORY}

In Late Miocene time numerous eruptions south of the Castle Rock area sent over 25 pahoehoe flows and brecclas of the "unnamed igneous complex" to bury the pre-Tertiary strata to a depth of at least $650 \mathrm{~m}$. While this complex of lava flows was building up, small streams were dammed and lava flows spiling into the temporary lakes formed palagonitic breccias. In some instances brecclas displaced water or built barriers allowing the lava flows to flow across or around lakes and solidify as compact lava. Some of the pahoehoe flows may have reached the proportions of flood basalts in volume and other relatively thin flows ponded by filling depressions and solidifled as lakes of lava, developing a contorted columar joint pattern as the lava slowly moved during cooling. Time intervals between flows were not long enough for soll horizons to develop, although small deposits of stream gravels and diatomite accumulated locally. After volcanism ceased a perlod of quiescence allowed nearly $800 \mathrm{~m}$ of erosional and structural relief to develop within the "unnamed Igneous complex."

Eruption of the rhyolitic Dinner Creek Ash-Flow Tuff from the areas of Castle Rock and Black Butte marked the beginning of a new volcanic episode. Alr-fall pumice lapilil marked the resumed volcanic activity and was shortly followed by the eruption of the Dinner Creek Welded Ash-Flow Tuff 
originated as a fiery cloud (nuée ardente) from the vent at Black Butte and zones of flank eruptions, one of which is represented by the dike at Castle Rock. Hot avalanche deposits indicate that several exuptions took place within a short time interval. Before or contemporaneous with extrusion, a north, north-south fault system developed within the older basaltic rocks. During this eruptive phase the basaltic flows between Black Butte and Castle Rock were uplifted and subsequently collapsed after volcanlc activity ceased. Considerable erosional and structural rellef developed in the Dinner creek Tuff sheet, re-exposing basaltic flows of the "unnamed Igneous complex" in places. Thick accumulations of volcaniclastics, rhyolitic lava flows and brecclas of the Strawberry Volcanlcs then filled a basin around Black Butte and Lost Creek Valley. These sillcic volcanics were In turn capped by a succession of basalt and dacite lava flows. These volcanic strata were folded into a broad anticline and syncline with strata around Black Butte, dipping circularly Inward, reflecting subsidence in that area. Faults also developed with continued tectonic adjustment.

A period of exosion and continued faulting preceded deposition of the tuffaceous sediments of the Juntura Formation, which restricted these Late Mlocene to Early Pliocene lacustrine sediments to a basin in the southern half of the area. These strata are the only extensive sedimentary rocks exposed within the area. 
By the Middle Pliocene age a volcanic eruption far to the south in the reglon around Burns sent the Drewsey Tuff ash-flow Into the Castle Rock area (Greene, 1973). By the time the ash flow reached this region $1 \mathrm{t}$ was as thin as $4 \mathrm{~m}$ and its northward fourney ended on the lower slopes of the mountains in the northern half of the area. After deposition of the Drewsey Tuff a minor lake formed in the southwest corner of the area where tuffaceous sediments were deposited on top of the ash-flow.

In plefstocene time a river flowed across the southwest corner of the area. This stream had a very low gradient and planed the soft lacustrine sediments into a broad, flat valley. Along tributary streams alluvial fans formed and landslides developed and are exposed today on the southwest end of the Castle Rock ridge, stranded 470 m above the present stream level.

In recent times, the North Fork of the Malheur River has cut back down through most of the lacustrine sediments, exposing older volcanlc rocks and leaving the pleistocene pediments, landslides, and alluvial fans stranded high above the present stream level. New alluvial fans and landsildes are developing along the present-day river. Faulting has probably continued to the present day and although no recent volcanism has occurred, the presence of hot springs and hydrothermal alteration suggest it is only dormant. 


\section{REFERENCES CITED}

Arnold, C. A., 1937, Observations on the fosstl flora of eastern and southeastern oregon: Contributions Univ. Mich. Muse um Paleont., v. 5, pt. 1, p. 79-102.

Axelrod, D. I. (1944), The Alvord Creek Flora; Carnegie Inst. Wash. Pub. 553, Contr. Paleontology, pp. 225-262.

- 1950, Evolution of desert vegetation in western North America: Carnegle Inst. Washington Pub. 590, P. 217-306.

, 1968, Tertiary flora and topographic history of the Snake River Basin, Idaho: Geol. Soc. America Bull., v. 79, No. 6, P. 713-734.

Baldwin, E. M., 1964, Geology of Oregon, 2nd edition: Eugene, Univ. Oregon Coop. Book Store, $165 \mathrm{p}$.

Beaulieu, J. D., 1972, Geologic formations of eastern oregon: Oregon Dept. Geol. and Mineral Indus. Bull. 73,80 p.

Bowen, R. G., 1956, The geology of the Beulah area, Malheur County, Oregon: Unpubilshed M.S. Thesis, Univ. of Oregon, $80 \mathrm{p}$.

, Gray, W. L., and Gregory, D. C., 1963, General geology of the northern Juntura Basin: chpt. 2 in Shotwell, J., A., 1963, The Juntura Basin: studies in earth history and paleontology: Am. Philos. Soc. Trans., v. 53 (new Ser.), pt. 1, $77 \mathrm{p}$.

Bowman, F. J., 1943, Vertebrate foss1ls from the Ironside Mountain quadrangle, Oregon, a supplement to Geology of the northeast quarter of the Ironside Mountain quadrangle, Oregon by $W$. D. Lowry, Rochester doctoral dissertation.

Brown, C. E., and Thayer, T. P., 1966, Geologic map of the Canyon City quadrangle, northeastern oregon: U. S. Geol. Survey, M1sc. Geologic Investigations Map I-447.

Brown, S. G., and Newcomb, R. D., 1962, Ground-water resources of Cow Valley, Malheur County, Oregon: U. S. Geol. Survey Water-supply Paper 1619-m, $38 \mathrm{p}$.

Carlat, J. E., 1954, Geology of the southwest portion of the Jamieson quadrangle, Oregon: Univ. Oregon Master's Thes is. 
Chaney, R. W., 1922, Notes on the flora of the Payette formation: Am. Jour. Sc1., ser. 5, v. 4, p. 214-222.

- 1959, Miocene floras of the Columbla Plateau: Carnegle Inst. Washington Contr. to Paleont., Pub.617, $134 \mathrm{p}$.

Corcoran, R. E., 1953, The geology of the east-central portion of the Mitchell Butte quadrangle, Oregon; Univ. Oregon Master's Thesis.

, 1965, Geology of Lake Owyhee State Park and vicinity, Malheur County, Oregon: The Ore Bin, v. 27, no. 5, p. 81-98.

,; Doak, R. A.; Porter, P.W.; Pritchett, F. I.; and Privrasky, N. C., 1962, Geology of Mitchell Butte quadrangle, Oregon: Oregon Dept. Geology and Mineral Industries Geol. Map Series, GMS-2.

Dale, R. H., 1957, Geology of the southwest quarter of the Dale quadrangle, Oregon: Univ. Oregon Master's Thesis.

Dicken, S. N., 1965, Oregon geography, 4th ed.: Edwards Brothers, Inc., Ann Arbor, Michigan, $147 \mathrm{p}$.

Doak, R. A., 1953, The Geology of the Double Mountain-Grassy Mountain Area, Mitchell Butte Quadrangle, Oregon; M. S. Thesis, Univ. of Oregon (unpubilshed).

Dole, Hollis M, and Corcoran, R. E., 1954, Reconnaissance geology along U. S. Highway 20 between Vale and Buchanan, Malheur and Harney Counties, Oregon: oregon Dept. of Geology and Mineral Industries, The ore BIn, v. 16, No.6, p. 37-39.

Donath, F. A., 1962, Analysis of Basin-Range structure, southcentral Oregon: Geol. Soc. America Bull., v. 73, p. 1-16. , and Kuo, J.T., 1962, Seismic-refraction study of block faulting, south-central oregon: Geol. Soc. America Bul1. v. 73, no. 4, p. 429-434.

Evernden, J. F., Savage, D. E., Curtis, G. H., and James, G. T., 1964, Potassium-argon dates and the Cenozolc mammilian chronology of North America: Am. Jour. Sc1., v. 262, p. 145-198.

Fisher, R. V., 1967, Early Tertiary deformation in north-central Oregon: Am. Assn. Petroleum Geologist Bull,, v. 51, No. 1 , p. 111-123. 
Fouch, T. D., 1968, Geology of the northwest quarter of the Brogan quadrangle, Malheur County, Oregon: Univ. Oregon Master's Thesis, $62 \mathrm{p}$.

Fuller, R. E., 1931, The geomorphology and volcanic sequence of Steens Mountains in southeastern oregon: Un1v. of Washington Pub. In Geology, v. 3, p. 1-130.

George, W. D., 1924, The Relation of the Physlcal Properties of Natural Glasses to Their Chemical Composition:

Jour. Geo1. Vol. 32, pp. 353-372.

Gilbert, G. K., 1928, Studies In basin-range structure: U. S . Geol. Survey Prof. Paper 153, 92 p.

Gray, W. L., 1956, Geology of the Drink1ng Water Pass area, Harney and Malheur Counties, Oregon: Unpublished M. S. Thes1s, Un1v. of Oregon, 86 p.

Gregory, C. D., 1962, The geology of the Stinking Water Creek area, Harney County, oregon: Unpublished M. S. Thesis, Unfv. of Oregon, $59 \mathrm{p}$.

Green, A. R., 1962, Geology of the Crowley area, Malheur County, Oregon: Unpublished M. S. Thes 1s, Un1v. of Oregon, $149 \mathrm{p}$.

Greene, R. C., 1973, Petrology of the welded tuff of Devine Canyon, southeastern oregon: U. S. Geol. Survey Prof. Paper $797,26 \mathrm{p}$.

, Walker, G. W., and Corcoran, R. E., 1972, Geolog1c Map of the Burns quadrangle, Oregon: U. S. Geol. Survey Misc. Geol. Inv. Map I-680.

Haddock, G. H., 1967, The Dinner Creek welded ash-flow tuff of the Malheur Gorge area, Malheur County, oregon: Univ. of Oregon doctoral dissert., $111 \mathrm{p}$.

Hagood, A. R., 1963, Geology of the Monument Peak area, Malheur County, Oregon: Unpublished M. S. Thesis, Univ. of oregon, $165 \mathrm{p}$.

Johnson, A. M., 1961, Stratigraphy and 11thology of the Deer Butte Formation, Malheur County, oregon: Unpublished M. S. Thes1s, Univ. of Oregon, $142 \mathrm{p}$.

K1rkham, V. R. D., 1931, Revision of the Payette and Idaho Formations: Jour. Geol., vol. 39, pp.193-239.

Kittleman, L. R., 1962, Geology of the Owyhee Reservolr area, Oregon: Unpublished Ph. D. doctoral dissert., Univ. of oregon, $174 \mathrm{p}$. 
Kittleman, L. R., 1963, Glass-bead determination for a sulte of volcanic rocks from the Owyhee plateau, oregon:

Geo1. Soc. America Bull., v. 74, p. 1405-1410.

, Green, A. R., Hagood, A. R., Johnson, A. M., McMurray, J. M., Russell, R. G., and Weeden, D. A., 1965 , Cenozolc stratigraphy of the Owyhee region, southeastern Oregon: Museum of Natural llstory, Univ. of Oregon, Bull. no. 1, 45 p.

, 1967, Geologic map of the Owyhee reglon, Malheur County, Oregon: Museum of Natural History, Unfv. of Oregon, Bu11. no. 8 .

Knowlton, F. H., 1898, Foss1l plants of the Payette formation: U. S. Geol. Survey 18 th Ann. Rept. pt. 3, p. 721-744.

1902, Fossil flora of the John Day Basin, Oregon: U.'S. Geol. Survey Bul1. 204, p. 1-151.

Laursen, Mckee, J., and Hammond, P. E., 1974, Summary of radiometric ages of oregon and Washington rocks, through June 1972: Isochron/West, No. 9, $32 \mathrm{p}$.

Lowry, W. D., 1943, Geology of the Northeast Quarter of the Ironside Mountain quadrangle, Baker and Malheur Counties, Oregon, Unpublished Ph. D. doctoral dissert., Univ. of Rochester.

, 1968, Geology of the Ironside Mountain quadrangle, Oregon: Oregon Dept. Geology and Mineral Industries, open flle rpt., 79 p. 31 figs., 2 tables, geol. map.

Malde, H. E., 1959, Fault zone along northern boundary of western Snake River Pla1n, Idaho, Sclence, v. 130, p. 272.

Mathews, W. H., 1951, A useful method for determining approximate composition of fine-grained igneous rocks: Am. Mineralogist, v. 36, p. 92-101.

McKee, Bates, 1972, Cascadia, New York, N. Y., McGraw H111 Book Co.,

McMurray, J. M., 1962, Geology of the Freezout Mountain area, Malheur County, Oregon: Unpublished M. S. Thesis, Univ. of Oregon, 87 p.

Merriam, J. C., 1916, Mammalian remains from a Late Tertiary formation at Ironside, Oregon, Univ. Cal1f. Pub. Dept. Geo1. Bu11., v. 10, no. 9 .

Moody, J. D., and Hill, H, J., 1956, Wrench fault tectonics: Geol. Soc. America Bu1l., v. 67, p. 1207-1246. 
Pardee, J. T., 1941, Preliminary geologic map of the Sumpter quadrangle, oregon: Oregon Dept. Geology and Mineral Industries map.

Porter, P. W., 1953, Geology of the Lower Sucker Creek Area, Mitcheli Butte Quadrangle, oregon: M. S. Thes1s, Univ. of Oregon (unpub1ished).

Pritchett, F. I., 1953, Geology of the western portion of the Mitchell Butte quadrangle, Malheur County, Oregon: Unpublished M. S. Thes1s, Univ. of oregon, 81 .

Privrasky, N. C., 1953, Geology of the northeast portion of the Mitchell Butte quadrangle, Oregon: Unpublished M. S. Thesis, Univ. of Oregon, 87 .

Ross, C. S., and Smith, R. L., 1961, Ash-flow tuffs: Their origin, geologic relations and identification: U. S. Geol. Survey Prof. Paper 366,81 p.

Russe11, I. C., 1902, Preliminary Report on Artesian Basins in Southwestern Idaho and Southeastern Oregon: U. S . Geol. Survey Water Supply Paper 78, pp. 37-38.

- 1903, Notes on the Geology of Southeastern Oregon: U. S. Geol. Survey Bul1. 217 .

Russe1l, R. G.,1961, Geology of the Cedar Mountain Quadrangle, eastern Oregon: Unpublished M. S. Thesis, Univ. of Oregon, $41 \mathrm{p}$.

Scharf, D. W., 1935, A Mlocene mammalian fauna from Sucker Creek, southeastern oregon: Carnegie Inst. Washington Pub. 453, p. 97-118.

Shotwe1l, J. A., 1958, Evolution and blogeography of the Aplodontid and Mylaqaulid rodents: Evolution, v. 12, p. 451-484.

, 1963, The Juntura Basin: studies in earth history and paleoecology: Am. Philos. Soc. Trans., v. 54 (new ser.), pt. 1 .

, J.A., and Russell, D. e., 1963, Mammallan fauna of the upper Juntura Formation, chpt. 4 in Shotwell, J. A., 1963, The Juntura Basin: studies In earth history and paleoecology: Am. Philos. Soc. Trans., v. 53 (new ser.), pt. 1 .

Smlth, H. V., 1932, The fossil flora of Rockville, Oregon: Unpublished M. S. Thes1s, Un1v. of Oregon, 44 p. 
Smith, H. V., 1938, Some new and interesting Late Tertiary plants from Sucker Creek, Idaho-oregon: Torrey Botanical Club, Bull., v. 65, P. 557564 .

- 1939, Additions to the fossil flora of Sucker creek, oregon: Mich. Acad. Sc1., Papers for 1938, v. 24,

p. 107-121.

- 1940, Notes on the systematic and ecological implications of the Mlocene flora of Sucker Creek, oregon and Idaho: Am. Midland Naturalist, v. 24, p. 437-443.

Smith, R. L., 1960a, Ash flows: Geol. Soc. America Bull., v. 71, p. 795-842.

- 1960b, Zones and zonal variations in welded ash-flow tuff: U. S. Geol. Survey Prof. Paper 354-F, p.149-159.

Thayer, T. P., 1958, Some relations of later Tertiary volcanology and structure in eastern oregon (abs.):

Washington Acad. Sc1. Jour., v. 48, no. 4, p. 133-134, Apri1 1958 .

, and Brown, C. E., 1964, Pre-Tertiary orogenic and plutonic intrusive activity in central and northeastern oregon: Geol. Soc. America Bull., v. 75, no. 12, p. $1255-1262$.

, and Brown, C. E., 1973, Ironside Mountain, Oregon:

A Late Tertiary volcanic and structural enlgma:

Geol. Soc. Am. Bull,, vol. 84, no. 2, p. 489-497.

Thomas, G. M., 1956, Geology of the northeastern third of the Ritter quadrangle, Oregon, Univ. Oregon Master's Thesis.

Thompson, C. J., 1956, Geology of the northern third of the Susanville quadrangle, Oregon: Univ. Oregon Master's Thesis.

Tilley, C, E., 1922, Density, refractivity, and composition relations of some natural glasses: Min. Mag., v. 19, p. 275-294.

Walker, G. W., 1973, Preliminary geologic and tectonic maps of oregon east of the $121 \mathrm{st}$ meridian. U. S. Geol. Survey, Misc. Geol. Inv. map MF-495.

, Dalrymple, G. B., and Lanphere, M. A., 1974, Index to potassium-argon ages of Cenozolc volcanic rocks of oregon: U. S. Geol. Survey Misc. Field Studies Map MF-569. 
Wallace, R. E., 1946, A Mocene mammalian fauna from Beatty (Beatys) Buttes, oregon: Carnegie Inst. Washington Pub. 551, P. 113-114.

Washburne, C. W., 1911 , Gas and ofl prospects near Vale, Oregon, and Payette, Idaho: U. S. Geol. Survey Bull. $431, P .26-55$.

Weeden, D. A., 1963, Geology of the Harper area, Malheur County, Oregon: Unpublished M. S. Thesis, Untr. of Oregon, $94 \mathrm{p}$.

Wilkinson, W. D., 1950, Welded Tuff Members of the Rattlesnake Formation: Abstr., Geol. Soc. Am. Proc., v. 61, no. 12, pt. 2 .

W11kerson, W. L., 1958, The geology of a portion of the southern Steens Mountains, oregon: Unpublished M. S. Thes1s, Untv. of Oregon, $89 \mathrm{p}$.

Wolff, E. N., 1965, The geology of the northern half of the Caviness quadrangle, oregon: Unpublished Ph.D. Thesis Univ. of oregon, $200 \mathrm{p}$.

Wray, C. F., 1946, The geology of the northwest quarter of the Ironside Mountain quadrangle, Grant and Baker Counties, oregon: Rochester Univ. Master's Thesis, 82 p., geol. map. 
APPENDIX A

STRATIGRAPHIC SECTION DESCRIPTIONS

SECTION 1: UNNAMED IGNEOUS COMPLEX

SECTION 2: STRAWBERRY VOLCANICS

SECTION 3: JUNTURA FORMATION 


\section{APPENDIX A}

SECTION 1: UNNAMED IGNEOUS COMPLEX

(Descriptions are below, section appears in Fig. 10 in text.)

\section{CASTLE ROCK SECTION}

(Secs. $15 \& 16, T, 18 \mathrm{~S},, \mathrm{R}, 37 \mathrm{E}$, , at the southeast end of the Castle Rock ridge.)

25. Dense fine-gralned basalt:

Dark-gray to black, reddlsh where

weathered; fine-gralned, very dense

basalt. Blockey-jolnted. Upper $1.5 \mathrm{~m}$

of the flow is vestcular.

24. Dark, fine-gralned basalt:

Dark-gray to black; fine-gralned, plag1o-

clase rich basalt. Th1s flow has a lower

vesicular zone which grades upward into

a zone of columnar jointing with a $0.3 \mathrm{~m}$

joint spacing. Within the columade are

vesicle tubes consisting of vertical

three-dimensional tube-shaped structures

which are highly vesicular and surroun-

ded by dense lava. 6.0

22. Dark, fine-grained ollvine basalt:

Dark-gray to black; fine-gralned, plag1o- 
clase and olivine rich basalt. A $1 \mathrm{~m}$ thick vesicular zone at the base, overlain by a $5 \mathrm{~m}$ thick zone of columnar jolnting. 8.0

21. Dark, fine-grained basalt:

Dark-gray to black, weathering reddish in color; fine-grained basalt. An irregular vertical columnade with a 1 m joint spacing is common. Contacts are sharp.--- 7.6

20. Dark, fine-grained basalt:

Dark-qray to black, weathering red in color; fine-grained basalt. The lower 2 m of flow is dense with a poorly developed platy folnting and a $1.5 \mathrm{~m}$ vesicular zone is present below the upper contact. This flow has a normal remant magnetlc polarity.

19. Dark, medium-grained basalt:

Dark-gray to black; medium-gralned; pyroxene, olivine and plagioclase rich basalt. Many plagioclase crystals have a bluish cast, possibly indicating a labradoritic composition. Nearly the entire flow displays a highly irregular or contorted columar structure. Columns are horizontal In places and end abruptly into a 
Unnamed Igneous Complex

Meters

weathered surface at the top of the

flows.

36.5

18. Covered Interval:

Among basaltic talus, float from a

white crystal-11thic-tuff with black

glass fragments and a $11 g h t-c o l o r e d$

porcelinite type rock was found. -

17. Olivine basalt:

Medium-gray; medium to fine-gralned;

olivine, and plagloclase rich basalt.

Columnar jolnting is well-developed. - - 25.8

16. Olivine basalt:

Medium-gray; fine-gralned; dense, olivine and plagioclase rich basalt.

This flow has a very well-developed

columnade which has a $0.6 \mathrm{~m}$ joint

spacing and is $32 \mathrm{~m}$ thick. The tops

of the columns are radially bent

towards the south and southwest. This

may represent the downslope direction

of the flow, Indicating its source in

an east or northeast direction. This

flow might represent ponding of a

generally much thinner lava flow. The

upper $17 \mathrm{~m}$ of this unit is very poorly

exposed.

49.0 
15. Dense, fine-grained basalt:

Medium-gray, weatherling $11 g h t-g r a y ;$ fine-

grained; dense, basalt. The central

part of the flow is columnar jolnted with

flow laminations developed normal to the

columns. The lower 2 m of the flow is

a platy entablature. The upper contact

Is heav1ly mantled with talus.

14. Olivine basalt:

Dark-gray to black; fine to medium-

gralned olivine basalt. The lower $1.5 \mathrm{~m}$

of this flow is a compact scorlaceous

zone. This zone grades upward into 14 m

of entablature. Above the entablature

Is a $4.6 \mathrm{~m}$ vesicular zone.

19.8

13. Pillow-palagonite-breccia:

Dark to l1ght-brown, weathering to a

yellowish color; PIllows and basalt

fragments are generally porphyritic,

dense and palagonitic in the cores.

Plilows are encased in a thick crust

of dark glass and surrounded by a matrix

of fine-grained palagonitic breccia.

Plllows are commonly highly elongated or

flattened, some measuring $3 \mathrm{~m}$ in length

and only $0.3 \mathrm{~m}$ in thickness. Foreset 
Unnamed Igneous Complex

Meters

bedding dipping about N1OE may indicate a flow direction from the southwest. Fragments within the breccia have a weak normal remnant magnetic polarity. 30.0

12. Fine-grained porphyritic olivine basalt:

Dark-gray to black; fine-gralned, finely porphyritic olivine and plagioclase rich basalt. A well-developed $2.8 \mathrm{~m}$ thick columnade with a $0.5 \mathrm{~m}$ joint spacing is present at the base of the flow. Th1s columnade becomes very irregular near the top of the flow. 15.5

11. Fine-grained porphyritic olivine basalt:

Dark-gray to black; fine-grained basalt or basaltic andesite. Bright orange-red phenocrysts believed to be altered olivine form almost 2 percent of the hand specimen. Vesicularity Increases toward the top of the flow.

10. Dark, porphyritic olivine basalt:

Dark-gray to black; porphyr1tic, ol1vine and plagloclase rich basalt. This flow has a $1.5 \mathrm{~m}$ vesicular zone at 1ts base and is amygdaloldal in places. Phenocryst and vesicle fillings decrease in 
number upward in the section. The phenocryst distribution 1s probably related to crystal settling during flow. Increased number of vestcle flilings is probably related to the permeable nature of the basal contact and the much lower permeablitty of the flow's interlor. -

9. Olivine basalt:

Dark-gray to black; medlum to finegralned ollvine basalt. The basal part of the flow is dense. The upper portion Is highly vesicular and oxidized to a pale red color. Amygdales of a zeolite mineral are found scattered throughout the flow.

8. Porphyritic basalt:

Dark-gray to black; flne-gralned; porphyritic plagloclase and olivine rich basalt. Plagloclase phenocrysts may measure up to $6 \mathrm{~mm}$ in length and ollvine crystals may measure up to $2 \mathrm{~mm}$ in diameter. Phenocrysts are noticeably more abundant lower In the flow, suggesting crystal settling. Columar jolnting is poorly developed. The lower $3 \mathrm{~m}$ of this flow is a palagonitic breccia which grades upward into dense, 
dark-colored porphyritic basalt. The

transition zone, from palagonitic to

fresh lava is oxidized to shades of

lavender in places. This lava flow has

a normal remant magnetic polarity. ---- 15.2

7. Dark, fine-grained basalt:

Dark-gray to black; weathering to a

light-brown color; aphanitic basalt.

A poorly developed columnar jolnt set

with a $0.6 \mathrm{~m}$ spacing is common. The

flow breaks readily into blocks about

$0.3 \mathrm{~m}^{3}$.

6. Dark, fine-grained basalt:

Dark-gray to black; medium-grained to

aphanitic basalt. Three zones of

columar fointing are present above a

basal palagonitic zone. The zone contacts

are sharp and columns $0.3 \mathrm{~m}$ In width be-

come more Irregular near the top of the

flow. A basal $0.6 \mathrm{~m}$ thick vesicular

zone underlies a columnade. In places

the lower $1.5 \mathrm{~m}$ of the flow is a pala-

gonitlc breccia.

13.9 .

5. Dark, fine-gralned olfvine basalt:

Black to dark-gray; fine-grained, plag1o-

clase and olivine rich basalt. Columnar 
jointing with a 0.15 to $0.3 \mathrm{~m}$ spacing

is poorly developed. A $0.3 \mathrm{~m} \mathrm{thick}$

vesicular zone occurs near the basal

and upper contacts of the flow. 15.0

4. Light-colored, olivine basalt:

Medium to light-gray, weathering to

smal1 black to 11ght-brown pellets;

fine-grafined, plagloclase and olivine

rich basalt. An $8 \mathrm{~cm}$ foint spacing

is prominent.

14.0

3. Pillow palagonite breccia:

Basalt fragments are dark-gray; aphanitic

and dense. Outcrops weather into blocks

about $3 \mathrm{~m}^{3}$ in size related to an incon

sistent 3 m foint spacing. Basalt plilows

are several feet in diameter; many are

angular and broken and are surrounded by

a relatively fine palagonitic breccia.

Zeolitization is common in veins and cavi-

ties. Well-developed foreset bedding

indicating a flow direction on a bearing

of about N30W suggests deposition from

the southwest. The basal contact is deeply

eroded and dusted with diatomite. The

outcrop has an irregularly exposed upper

contact which weathers into rounded spires 
or pinnacles locally. $18.5-33.0$

2. Dense, aphanitic to porphyritic basalt:

Black to dark-gray, weathering to a dark reddish brown; dense, fine-grained aphanitic to slightly porphyritic basalt. outcrop displays a poorly-developed $10 \mathrm{~cm}$ joint spacing which decreases to $2.5 \mathrm{~cm}$ near the top, allowing the rock to fracture into small angular, platy fragments. The basal contact is deeply weathered below a 0.5 m vesicular zone.

1. Dark, coarse-grained olivine basalt: Black to dark-gray, weathering into black to light-brown pellets; medium to coarse-grained, almost diabasic, plagioclase and olivine rich basalt. The outcrop weathers into large bulbous masses about $1 . m$ in diameter formed from deeper weathering along foints. A $0.3 \mathrm{~m}$ vesicular zone is exposed below the upper contact of the flow. 9.0

- Poorly exposed lava flows of the "unnamed Igneous complex." 


\section{SECTION 2}

\section{STRAWBERRY VOLCANICS}

(Descriptions are below, sections appear in Fig. 16 in text.)

\section{Composite of Lost Creek Sections}

(Secs. 19 and 20, T. 17 S., R. 37 E., along Lost Creek.)

Strawberry Volcanics

Meters

28. Dark, aphanitic basaltic lava flow:

Dark-gray to black; aphanitic basaltic

or more silicic lava flow, with a

poorly developed greenish mineral layer-

Ing along platy folnting surfaces. - - - 22.5

27. Dark, aphanitic basaltic lava flow:

Dark-gray to black; very fine-grained

basaltic of more silicic lava flow.

Green mineral layering, probably altera-

tion products occur along a primary flow

layer1ng.

27. Dark, aphanitlc basalt:

-

Dark-gray to black; aphanitic, basaltic

lava flow $\left(\mathrm{SIO}_{2}=46 \pm 2\right.$ percent, sample

75JW081, App. B, Tab. 3). The outcrop

shows some viscous flow structures common

to moresilicic flows and green mineral

laminations along flow layering. A reddish 
baked zone occurs below the basal

contact. -

25. Covered Interval:

Heavy manting of basaltic talus. -

24. Porphyritic basa1t:

Medfum-gray, weathering $11 g h t-g r a y$; open-

textured, porphyritfc, olivine and plagio-

clase rich basalt.

23. Porphyritic basalt:

Medfum-gray, weathering $11 g h t-g r a y$; open-

textured, porphyritic olivine and plagto-

clase rich basalt. Plagioclase pheno-

crysts measure up to $3 \mathrm{~mm}$ in length.

This flow is very similar to unit $22 . \ldots-9.1$

22. Porphyritic basalt:

Medium-gray, weathering light-gray; open-

textured, porphyritic, olivine and plagio-

clase rich basalt. A rudely developed

columnade with a $0.6 \mathrm{~m}$ to $1.2 \mathrm{~m}$ joint

spacing is common. The flow is finely

vesicular from top to bottom and displays

blue and green mineral coatings on some

vestcle interiors.

21. L1ght-brown, pumice lap1111-tuff:

Light-brown, dark-brown when weathered;

pumice fragments measure up to $15 \mathrm{~cm}$ 
in length but most are lapilil size.

The upper part of the tuff has been

oxidized to a bright orange color,

where $1 \mathrm{t}$ was baked by the overlying

lava flow

20. Light-brown, pumice lapili1-tuff:

Light-brown, dark-brown to dark-gray

where weathered. Slightly elongated

pumice fragments and obsidian-1ike glass

fragments about $0.75 \mathrm{~cm}$ in length are

common. The lower 6 m of this unit

is Inciplently welded and weathers into

bulbous, hoodoo-l1ke masses. The central

$7.6 \mathrm{~m}$ part of this unit is $11 \mathrm{ght} 1 \mathrm{y}$

welded and grayer in color. This zone of

light welding stands out in outcrop in a

pseudo-columnade.

19. Covered Interval:

Heavy soll cover.

18. Black, aphanitic andesite:

Black to dark-gray; glassy, aphanitic andestee $\left(\mathrm{SIO}_{2}=52 \pm 2\right.$ percent, APP. B, Tab. 3). There is a $4.6 \mathrm{~m} \mathrm{basal}$ ves 1 cular zone with vesicles showing elongation due to flowage. Above this, is a 32 m thick zone of contorted fointing 
along mineral layering and ramping

structures. An upper auto-brecclated

zone about $3 \mathrm{~m}$ in thickness is also

present. -

17. Covered Interva1:

Heavy so11 and talus. 8.0

16. Brownish-gray pumice lapi111-tuff:

Light to medium brownlsh-gray; consisting of 10 percent elongated pumlce fragments and 5 percent 11 thic fragments ranging from 0.5 to $2.5 \mathrm{~cm}$ in length. The matrix is a fine dark-brown pumiceous ash which gives the rock a dirty appearance. This unit is easily eroded due to its general incompetence and a widely spaced joint set. The upper part of the unit is more resistant but large cavities have been weathered into it. - 52.0

15. Covered interval:

Heavy soil cover.

14. Pumiceous crystal 1api111-tuff:

Light brownish-gray; pumice fragments are orange, black, and gray, averaging about $4 \mathrm{~mm}$ in diameter. Feldspar crystals and glass fragments up to $4 \mathrm{~mm}$ 
in length are present. A matrix of

light-gray ash comprises 70 percent

of the rocks.

13. Covered Interval:

Heavy so11 cover.

12. Pumiceous sedimentary ash:

Light brownish-gray to white; the lower

2 to $3 \mathrm{~m}$ is very fine and easily eroded ash whlle the upper 2-3 m is composed of reworked tuff, darker in color and much more resistant to erosion. This upper, coarser-gralned zone has black glass and lithic fragments about $4 \mathrm{~mm}$ in diameter. - 4.5

11. Dark, fine-grained silicic lava flow:

Black to dark-gray; glassy, aphan1tic with pinkish glassy streaks and green mineral banding along flow layering.

10. Light, pumice lapili1-tuff:

Light to medium brownish-gray; lightly welded and composed of orange, white, and black pumice fragments and black obsidianlike glass fragments in a matrix of brown ash.

9. Pumfce lap1111-tuff marker bed (Tsvm):

Medfum-gray; pumfce fragments average

$3 \mathrm{~cm}$ in diameter within a groundmass of 
smaller 11ght-gray pumfee and dark-glass

fragments averaging $4 \mathrm{~mm}$ in diameter.

The unt has a poorly-developed vertical

foint set and a horizontal platy foint-

ing with a $0.6 \mathrm{~m}$ spacing. This unit

is lightly welded and in places forms

ledges. The lower $1.5 \mathrm{~m}$ 1s composed

of white to light-gray sedimentary ash

which readily weathers and is very

uniform in thickness.

8. Pumice 1apil11-tuff:

Medium-gray, pumfee fragments average 3

cm In diameter within a groundmass of

smaller light-gray pumice and dark glass

fragments averaging $4 \mathrm{~mm}$ in diameter, being

very similar to unit 9. Fragments increase

In size towards the top where they are

about four times as large. This unit

weathers into hoodoos or spires.

7. Covered interva1:

Heavy soll cover.

6. Light, ashy pumice bed:

Light-gray, weathering to a 11 ght to medium-brown. where weathered. This unit

1s rhythmically layered with fine and coarser pumlce fragments with some larger 
lenses of white pumiceous ash. 3.0

5. Volcanic conglomerate:

Yellow to brown; coarse-textured, volcanic conglomerate consisting of about 50 percent reworked tuff-breccia.

Elongated or flattened pumice fragments measure up to $15 \mathrm{~cm}$ in length. Basaltic and silicic 1tthic fragments comprise about 50 percent of the unft. These fragments are nonsorted and most commonly fall within a 0.5 to $7.5 \mathrm{~cm} \mathrm{size}$ range. -

4. Volcanic sandstone:

Medium to 11 ght-gray; well compacted and moderately dense. Bedding structures are well-developed.

3. Light, pumfce 1ap1111-tuff:

Light-gray to brown; pumice fragments are elongated and flattened within a groundmass of ash. Fragments decrease in size upward within the unit. Lenses of coarser material appear at the base of the unft and lithic fragments of basalt up to $5 \mathrm{~cm}$ in length are present. Bedding structures are well-developed near the top of the section. - 
2. Light, pumice lapi111-tuff:

Light to medium-gray; obsidian-1ike

glass fragments and lithic fragments of pumice average about $4 \mathrm{~mm}$ in diameter within a matrix of fine mediumgray ash. This unit is nonwelded and the top 1.5 m shows fine bedding structures. Immediately above this unit a thin layer of white ash possibly mixed with some diatomite. This is a distinctive marker bed where exposed.

1. Pumice lapilil-tuff:

Graylsh-purple to white; composed of lap1111-size pumice fragments in a variety of colors with a few fragments of Dinner Creek Tuff and basalt. This unit shows signs of sedimentary reworking and has an irregular contact above the Dinner Creek Ash-Flow Tuff. 3.0

- Dinner Creek Welded Ash-Flow Tuff 


\section{SECTION 3}

JUNTURA FORMATION

(Descriptions are below, section appears in Fig. 19 in text.)

\section{Jerry Canyon Section}

(NE $1 / 4 \mathrm{SW} 1 / 4$ sec. 23 T. $18 \mathrm{~S} .$, R. 37 E.; at the southeast end of Jerry Canyon.)

23. Light, pumice lap1111-tuff:

Light to medium-brown; dense, fibrous pumice fragments from $2 \mathrm{~mm}$ to $1 \mathrm{~cm}$ in size comprise about 30 percent of the rock. Lithic fragments and crystals are sparse and a matrix of fine ash forms about 65 percent of the rock. The upper 3 m of this flow has been completely reworked by sedimentary processes and bedding structures are - we11-developed. 4.5

22. Light, tuffaceous sandstone:

Light to medium-gray; very fine-grained with interbedded layers of white to 1ight-brown pumice and 1ithic fragments. 
21. L1ght, welded ash-flow tuff:

L1ght brown1sh-gray; 11ghtly to moderately welded, composed of welded and/or devitrified ash size pumfee fragments with minor crystals and lithic fragments. Some pumice fragments measure up to $1.5 \mathrm{~cm}$ in length, but $2 \mathrm{~mm}$ in diameter Is the most common size. Light orange, brown, gray and reddish pumice fragments are welded densely enough to make this flow a good ridge former. - 7.5

20. Light, pumice lap1111-tuff:

Light to medium bluish-gray; well compacted. Medium to dark-gray pumice fragments averaging $5 \mathrm{~mm}$ In length comprise from 50 to 10 percent of this rock. These fragments show flattening in places and are well embedded in a bluish-gray coarse pumaceous ash. Ash fragments are $2 \mathrm{~mm} 1 \mathrm{n}$ diameter or smaller. 4.5

19. Covered Interval:

Heavy sol1 cover.

18. Light, pumfce lapilli-tuff:

Light to medium-brown; composed of dense 
fibrous pumice fragments ranging from

$2 \mathrm{~mm}$ to $1 \mathrm{~cm}$ in size comprising up to

30 percent of the rock. Medium-gray

and black lithic fragments averaging

less than $2 \mathrm{~mm}$ in length comprise 3 to

5 percent of the rock and a fine, light-

gray to buff-colored pumiceous ash forms

the matrix. $-(-5-5$

17. Porphyritic basalt:

Dark-gray to black; very fine-gralned,

dense porphyritic basalt. Plagloclase

phenocrysts about $2 \mathrm{~mm}$ in length and

olivine comprise over 10 percent of the

rock. Locally the glassy groundmass has

a lavender tinting in places.

16. Olivine basalt:

Medium to dark-gray; weathering to a dark

to medium-brown; fine-grained, and dense

with a poorly developed platy jolnting.

This flow is poorly exposed and weathers

to a sandy material in places.

15. Covered material:

Heavy sol1 cover.

14. Light, pumice lapil11-tuff:

Light-brown; lightly welded, ash-flow

tuff. This rock is composed of 50 percent 
white fibrous pumice, 30 percent sanidine crystals within a matrix of lightcolored ash and minor 11 thic fragments. - - 3.0

13. Dark, fine-grained basalt:

Dark-gray to black, flne-grafned basalt. A columiar joint set with a 1 m spacing and a platy fointing developed normal to it are common. This flow is vesicular near the basal and upper contacts with a $0.3 \mathrm{~m}$ reddish oxidized baked zone at the base.

12. Dark, fine-grained olivine basalt:

Dark-gray to black weathering light-brown;

fine-grained, amygdaloldal olivine rich

basalt. The rock ttself is spotted with green alteration products and weathers to a fine-sand. The outcrop weathers to low profile bulbous masses about $0.3 \mathrm{~m}$ in width posslbly reflecting deep weathering along joints. A 0.2 baked zone forms the base of this flow.

11. Light-pumice lap1111-tuff:

Light to medium-gray; IIghtly welded, consisting of 40 percent large white flattened pumice fragments, ranging from 1 to $8 \mathrm{~cm}$ in length averaging about $2 \mathrm{~cm}$ in length, 2 percent black glass fragments averaglng 2 mm 
in diameter, 2 percent red and black Ithic fragments averaging $2 \mathrm{~mm}$ in diameter and minor sanidine and quartz crystals. Pink and gray pumice fragments averaging $1 \mathrm{~cm}$ in length comprise 10 percent of the rock and the remainder is a matrix of light-gray ash. Within the lower 3 m of the flow fragments are 50 percent smaller and the upper 3 m has been reworked and sorted by water action.--12.0

10. Light tuffaceous and volcanic sediments:

Alternating beds of $11 \mathrm{ght}-\mathrm{gray}$ and lightbrown beds of reworked pumaceous air-fall material. Light-brown beds have an ashy texture, while light-gray beds have a more sandy texture. About $10 \mathrm{~m}$ above the base of this unit are $0.8 \mathrm{~m}$ thick lenses of pebble conglomerate, probably of fluviatile origin. Lithic fragments with the conglome include quartzite, basalt, obsidian and pumice. Above the comglomerate lenses are $1.2 \mathrm{~m}$ of white very fine-grained tuffaceous sediments. - 12.0

9. Pumiceous crystal-1ithic tuff:

Light-brown to light-gray; loosely con- 
solidated, sanfdine crystals are

abundant. Lithle fragments comprise

15 percent of the rock and are red, green, gray, orange, and black in

color. Lap1111-size pumfce fragments

up to $2 \mathrm{~cm}$ in length form the bulk

of the rock. -

8. Porphyritic olivine basalt:

Dark-gray, med 1 um-gray where weathered;

medium to fine-grained, porphyritic

olivine and plagioclase rich basalt.

The lower $1.8 \mathrm{~m}$ of the flow is oxidized

to a bright reddish color and is highly

vestcular. The flow has another ves1-

cular zone below the upper contact. -

7. Pumfce 1api111-tuff:

Medium-brown, moderately dense, with

pumice fragments measuring up to $4 \mathrm{~cm}$

In diameter. The rock is 11 ghtly welded

and very tough with a fibrous texture. - - 3.0

6. Light, pumice lap1111-tuff:

Light-gray, weathering white; fibrous

pumice fragments average about $8 \mathrm{~mm}$

In length, form the bulk composition of

the rock. Lithic fragments and black glass

fragments comprise about 5 percent of

the rock. - 
5. Light, pumice lapil11-tuff:

Light-brown; pumice fragments average

$8 \mathrm{~mm}$ In length, surrounded by an ashy matr $1 x$.

4. Light, pumice lapilil-tuff:

Light to medium-gray; pumice fragments measure up to $2.5 \mathrm{~cm}$ in length and average about $8 \mathrm{~mm}$ in length. Less than 2 percent of this rock is composed of lithic fragments. The basal contact is sharp and the upper $10 \mathrm{~cm}$ of this unit has been reworked, possibly due to wind 5.0

3. Pumiceous 1ithic lapil1i-tuff:

Light green to yellowish gray, yellowish where weathered; Incipiently welded, composed of lithic and glass fragments comprising 5-10 percent of the rock, 11ghtbrown and 1 ight-gray pumice fragments compose 50 percent, and a fine greenish-gray to yellow ashy matrix with minor sanidine crystals comprise the remainder of the rock. Pumice, glass and 11 thic fragments are between 2 to $5 \mathrm{~mm}$ in length, generaliy much smaller than pumice fragments. Decomposition of light-colored pumice fragments 
and ashy groundmass into clays gives the rock a yellowish appearance. The basal contact 18 very sharp and conformable with unit $3 . \ldots$

2. Light, pumiceous ash:

Light greenish-gray, Incipiently welded, pumlceous ash. Light to dark-brown and gray to black pumice fragments about $2 \mathrm{~mm}$ In length comprise about 10 percent of the rock. Green1sh-gray, pum1ceous ash with small transparent crystals comprise the bulk of the rock.

1. Dark, porphyritic basalt:

Black to dark-gray, weathers dark to medlum brown in color. When weathered the flow forms large, rounded bulbous masses heavily mantled by a coarse, dark-brown, sandy decomposition products.

- Rhyolitic breccia of the Strawberry Volcanics ( Tsvr).

Tota 1 


\section{APPENDIX B}

\section{GLASS-BEAD SILICA DETERMINATION FOR A SUITE OF VOLCANIC ROCKS FROM THE CASTLE ROCK AREA, OREGON}

\section{INTRODUCTION}

The refractive index of a volcanic glass is inversely proportional to its silica content; the higher the silica content, the lower the refractive indices (stark, 1904; George, 1924; and others). For control purposes a correlation curve for a sulte of volcanic rocks from the nearby Owyhee Plateau (Kittleman, 1963) was obtained in order to plot glass-bead samples from the Castle Rock area. Th1s curve was experimentally derived, with refractive indicies plotted against chemically determined silfca (Fig. 26). These samples proved to fall along a near linear scale, with nearly all samples falling within a 1.8 percent error range belleved adequate for this test (Mathew, 1951). Refractive indices for rocks of the Castle Rock area were plotted on this graph in order to determine their silica content $( \pm 1.8$ percent). For additional control, a basalt standard (USGS, $W-1$ ) and an obsidian standard (USGS, 0-16) of known silica content were analyzed and plotted. A sample of Littlefield Rhyolite of known silica content (Haddock, 1967) was also plotted. The two U. S. Geological Survey standards were close to falling within the 1.8 percent error range and 


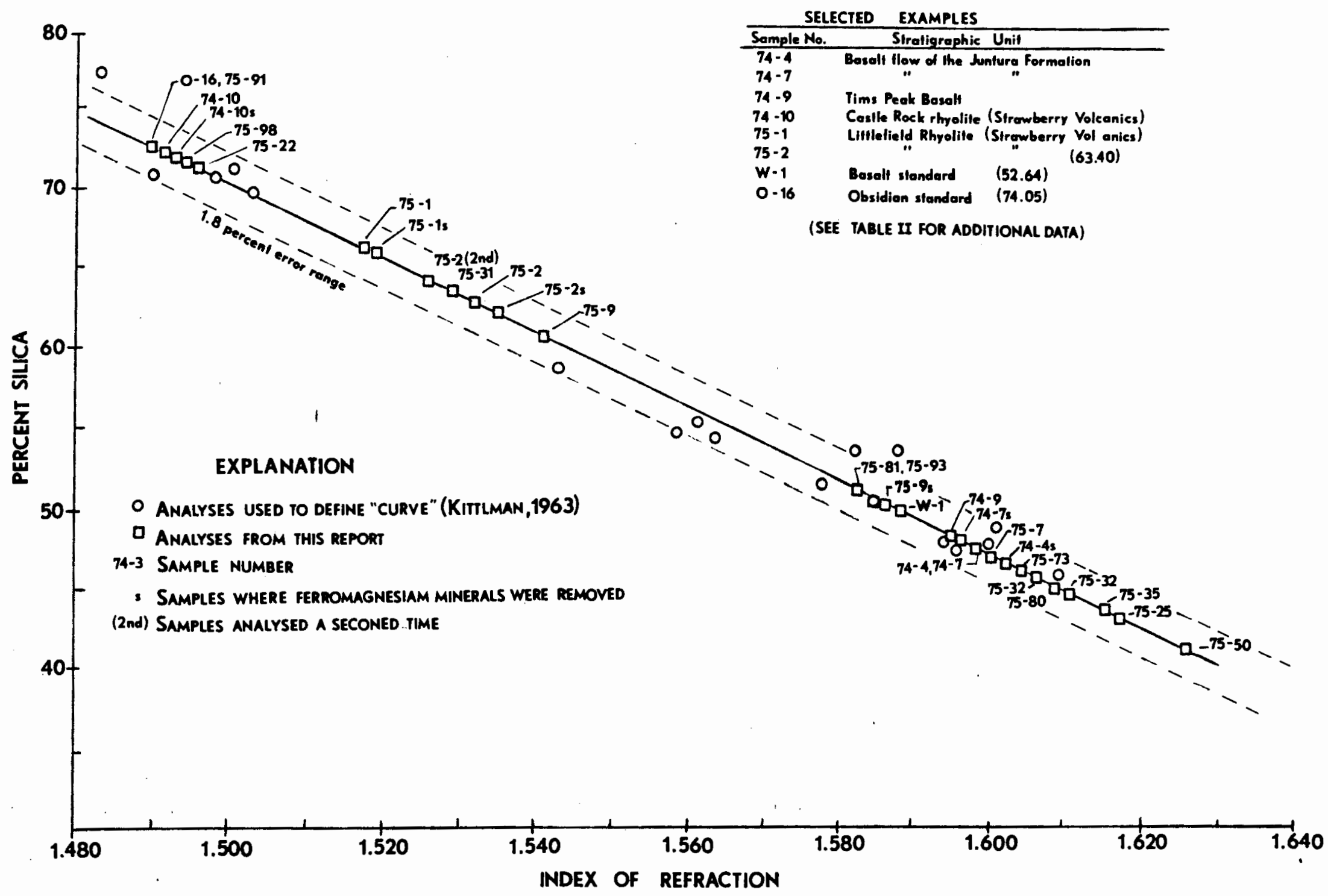

Flgure 26. Glass-bead silica determinations for a sulte of volcanic rocks from the Castle Rock area of eastern Oregon. 
the Littlefield rhyolite proved to be within a 0.5 percent error range.

Additional glass-bead analyses plotted in Figure 27 show an uneven chemical distribution of volcanic rocks with four major groups belng basalt, basaltic andesite, dacite and rhyolite. All analyses and the sample locations are Ifsted in Table 2, with their exact locations plotted on Plate 1 .

PRACTICAL APPLICATION

The glass-bead silica technique is simple, rapid, Inexpensive and may be done in the field. This method is adequate for correlation purposes and obtaining compositional control on black, glassy lava flows for classification purposes. The method is useful within areas of basalt, andesite and rhyolite associations, where rocks may be too fine-grained for modal analysis and mineralogy is deceptive. This method can be of assistance in recognition of the approximate composition of a rock, enabling determination of volumetric and stratigraphic distributions without a large number of expensive chemical analyses or tedious and often uncertaln microscope work. Besldes correlating stratigraphic units, compositional variations within ash-flows may be determined.

THE METHOD

a) A rock specimen (approximately 10 grams) is first 


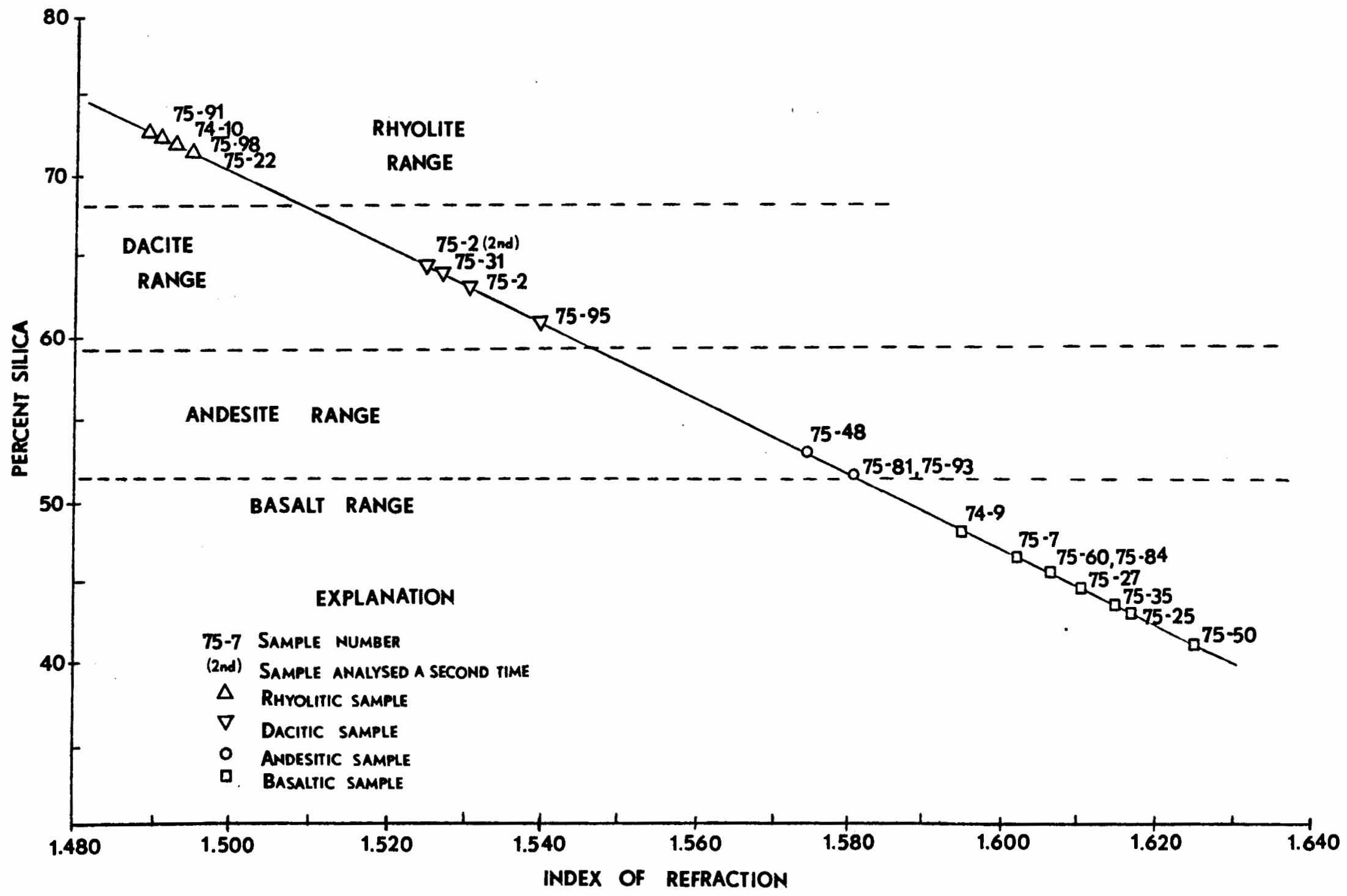

Figure 27. Scatter diagram showing the range in silica content of some volcanlc rocks from the Castle Rock area. Four compositional groups are recognized, with intermediate rocks confined to two general reglons on the diagram. 
TABLE II

SUMMARY OF GLASS-BEAD DETERMINATIONS FOR THE CASTLE ROCK AREA

\begin{tabular}{|c|c|c|c|c|c|c|c|}
\hline $\begin{array}{l}\text { Sample } \\
\text { Number }\end{array}$ & Formation & $\begin{array}{c}\mathrm{SiO}_{2} \\
\text { (Percent) }\end{array}$ & $\begin{array}{l}\text { Refractive } \\
\text { Index }\end{array}$ & Sec. & $\begin{array}{l}\text { Location } \\
\text { Township }\end{array}$ & Range & $\begin{array}{c}\text { Sample } \\
\text { Description }\end{array}$ \\
\hline $74 \mathrm{JW} 10$ & Tsv & 73.0 & 1.490 & 30 & T. $18 \mathrm{~s}$. & R. $37 \mathrm{E}$. & Rhy. brec. \\
\hline $75 \mathrm{JW02}$ & TsV & 64.0 & 1.526 & 33 & T. $18 \mathrm{~S}$. & R. $37 \mathrm{E}$. & sil. flow \\
\hline $75 J W 07$ & $T j b$ & 47.5 & 1.597 & 33 & T. $18 \mathrm{~S}$ & R. $37 \mathrm{E}$. & Bas. flow \\
\hline 75 JW07 & $T j b$ & 46.5 & 1.603 & " & 11 & 1 & Repeat \\
\hline $75 J W 22$ & TdC & 71.5 & 1.495 & 9 & T. $18 \mathrm{~S}$. & R. 37 E. & Rhy. ash-flow \\
\hline 75 JW25 & Tuic & 43.0 & 1.617 & 9 & T. $18 \mathrm{~S}$. & R. $37 \mathrm{E}$. & Bas. flow \\
\hline 75 JW27 & Tuic & 45.0 & 1.610 & 9 & T. $18 \mathrm{~s}$. & R. $37 \mathrm{E}$. & Bas. flow \\
\hline $75 \mathrm{JW} 31$ & TSV & 63.5 & 1.528 & 5 & T. $18 \mathrm{~S}$. & R. $37 \mathrm{E}$. & Sil. flow \\
\hline $75 \mathrm{JW} 32$ & TSV & 46.0 & 1.605 & $\overline{4}$ & T. $18 \mathrm{~S}$. & R. $37 \mathrm{E}$. & Bas. flow \\
\hline $75 \mathrm{JW} 35$ & TsV & 43.5 & 1.615 & 33 & T. $17 \mathrm{~S}$. & R. 37 E. & Bas. flow \\
\hline $75 J_{W 48}$ & Tsv & 52.5 & 1.574 & 31 & T. $17 \mathrm{~S}$. & R. $37 \mathrm{E}$. & And. flow \\
\hline $75 \mathrm{JW} 50$ & TSV & 41.0 & 1.626 & 29 & T. $17 \mathrm{~s}$ & R. $37 \mathrm{E}$. & Bas. flow \\
\hline $75 \mathrm{JW} 60$ & Tuic & 45.0 & 1.607 & $2 I$ & T. $18 \mathrm{~S}$. & R. $37 \mathrm{E}$. & Bas. flow \\
\hline $75 \mathrm{JW73}$ & TSV & 46.5 & 1.603 & 33 & T. $17 \mathrm{~S}$. & R. 37 E. & Bas. flow \\
\hline $75 J W 80$ & TsV & 45.5 & 1.608 & 11 & T. $18 \mathrm{~S}$. & R. $37 \mathrm{E}$. & Bas. flow \\
\hline $75 \mathrm{JW81}$ & TSV & 51.5 & 1.581 & 19 & T. $17 \mathrm{~S}$. & R. $37 \mathrm{E}$. & Bas. flow \\
\hline $75 J W 84$ & TsV & 45.0 & 1.607 & 19 & T. $17 \mathrm{~S}$. & R. $37 \mathrm{E}$. & Bas. flow \\
\hline 75 JW9 3 & TSV & 51.5 & 1.581 & 30 & T. $18 \mathrm{~S}$. & R. $37 \mathrm{E}$. & Bas. flow \\
\hline $75 \mathrm{JW98}$ & Tdt & 73.0 & 1.489 & 13 & T. $18 \mathrm{~s}$. & R. $37 \mathrm{E}$. & Rhy ash-flow \\
\hline
\end{tabular}

(See Plate I for exact locations) 
finely powdered to a sieve size less than 80 mesh with a machined steel mortar. All of any given rock fragment was crushed and no size fraction was discarded. This prevents any error due to differential breakdown of the varlous mineral constituents.

b) A magnetic separation was done with a small magnet to remove iron filings. Use of too strong of a magnet may result in removal of magnetite and other ferromagnesian minerals, resulting in increased error. The later separation may be done by dragging the magnet across the under side of a piece of paper containing the sample.

c) The sample is then fused into glass beads to homogenize the sample by the elimination of water and bringing the iron to a uniform oxidation state. The significant changes brought about in the composition of rock as a result of melting are essentially loss of the most volatile constituents, notably water, and changes in the oxidation state of iron.

A small amount of powder (approximately l gram) was then placed on an asbestos sheet and fused with a (double electrode) carbon arch torch to produce the glass beads. The torch was powered by a Lincoln arch welder set at about 60 amperes. The resulting glass beads range from about $0.5 \mathrm{~mm}$ to $1 \mathrm{~mm}$ in diameter.

d) The beads were then crushed and glass fragments free of Inclusions selected for measurement. 
e) Measurement of refractive Indfies was done with immersion oils in monochromatic sodium illumination directiy on the Ze1ss refractometer. Some beads have a small range of Indicies, in this case an estimated mean was used. Contaminants seen as microscopic inclusions are occasionally observed, probably carbon (Kittleman, 1963), as well as incompletely fused mineral fragments.

GENERAL OBSERVATIONS

The scatter diagram of Figure 27 defines an approximately linear trend, such that the percent silica can be estimated with an error of $\pm_{2}$ percent (K1ttleman, 1963). The maximum departure from a smooth curve on the sil1carefractive index diagram is 0.007 in index and 1.8 percent In silica content within rocks of the same volcanic sulte (Mathews, 1951). On a graph prepared by Kittleman (1963) of samples taken throughout North America, nearly all samples (126 in al1) fall within an error of 4.0 percent. According to Tilley (1922) the refractive Index rises at a rate of about 0.0033 for each additional percent water up to 3.3 percent. Water in small amounts can therefore have a significant influence on the refractive index. Differences in the degree of oxidation of lavas during and after extrusion may also create deviations from the composition and refractive index for a particular rock suite (Mathews, 1951). Observations made by Stark (1904) and George (1924) Indicate two glasses with the same refractive 
Index might differ In silica content by as much as 14 percent, or may differ by only 0.065 percent. Indicies are generally low if the silica content of the glass is high, and vice versa. The proportion of any one constituent, even the major constivents, do not alone determine the refractive index of a glass, but each constituent contributes according to its abundance and to its specific properties (Mathews, 1951). To examine the relative effect of iron on the refractive indicles of the Castle Rock samples, the magnetic minerals were separated out of those samples with the suffix-s of Figure 27. It is interesting to note that the separation of magnetic minerals has little effect on the more silicic volcanic rocks but may cause a variation in silica content by as much as 2 percent in basaltic rocks. In general, loss of iron tends to reduce the refractive indices of the more mafic samples and slightly increases the refractive indices of the more silicic samples. The net result is a higher silica content for basalts and a lower slifca content for more siliclc rocks. It is believed that other constituents such as magnesium, titanium and trace elements play an important part in determining the refractive Indicles of the glass beads.

Harker (1909) selected groups of 1gneous rocks, of one general locality and age, and showed that within such groups of igneous rocks in the same petrologic province, there are distinct similarities in silica content and bulk composition. If glassy, these rocks can be expected to have similar re- 
fractive indicles. Mathews (1951) expands on this by suggesting rocks representing comparable degrees of magmatic differentiation would contaln simflar amounts not merely of silfca, but also of alumina, iron, lime, and other essential constituents. 
gonite breccia of the "unnamed Igneous complex" formed the plane of movement for this slide. Other, smaller landslides of similar type occur throughout the area. Tuffaceous interbeds, brecclated flows or thin baked horizons may form slide planes within the lava flow complexes.

Sedimentary strata are more prone to minor slumping and soll creep. Irregular slumping within the Juntura Formation has caused displacement of the Drewsey welded tuff near the Castle Rock Ranch (Plate 1). The soft sediments show a continuous long-term soll creep at the Agency Valley Cemetery, where tombstones are cracked and tilted in random directions. Some of these tombstones are nearly 100 years old and their displacement indicates that soll creep is an important erosive process in the area.

\section{COLLUVIUM}

Colluvium mantles much of the Castle Rock area in the form of angular to rounded rock fragments, ranging in size from $2 \mathrm{~cm}$ to about 1 m In diameter. Cobble-size clasts of about $5 \mathrm{~cm}$ in diameter are most common. Colluvium is unsorted, clasts are angular and unevenly distributed. The Juntura Formation in the southern part of the area is covered with colluvium which acts as lag gravel or desert pavement, causing gently sloping benches to form, protecting the softer sediments from intense hoodoo weathering. These gravels are associated with minor deposits of rounded terrace gravels on the pediment surfaces along the east side of the 
North Fork of the Malheur River Valley. The long, gently dipping slopes of the Juntura Formation in the southeast corner of the area are also heavily laden with these gravels and may represent an extensive pediment which has undergone considerable erosion.

Sources of colluvium appear to be early talus slopes of older lava flows, small alplne and valley glaciers which ex1sted a short distance north of the Castle Rock area during the Pleistocene Epoch, and local talus slopes and alluvial fans. Sudden runoff from thunder storms has loosened the clayey regolith from around the gravels in places, causing channels to appear as long strips of cobble-size fragments. The pediments indicate that the anclent North Fork of the Malheur River once occupied a position almost $470 \mathrm{~m}$ above its present level during the Pleistocene Epoch.

\section{ALLUVIAL AND LACUSTRINE DEPOSITS}

Alluvial deposits are restricted to the flood plains of the major streams draining the area, namely, the North Fork of the Malheur River, the Little Malheur River and Lost Creek. This alluvium consists predominantly of cobble and gravel size detritus near stream banks with a heavy mantilng of clays and silts deposited at flood stages along the flood plain. These deposits are usually located upstream from bedrock obstructions in the stream. Intermittent streams often have beds of cobbles and gravels which may be substituted for roads in times of fair weather. 
Lacustrine deposits are restricted to the northern end of Beulah Reservolr which receives heavy runoff in the spring and late fall months. Since all of the runoff from the Castle Rock area and a much larger surrounding area must pass through Beulah Reservoir, heavy thunder storms fill the reservolr and back waters into the valleys of Warm Springs creek and the North Fork of the Malheur River. 


\section{HY DROTHERMAL ALTERATION}

An area of hydrothermal alteration covering about $1 \mathrm{~km}^{2}$ was found $2 \mathrm{~km}$ southwest of Castle Rock (Plate 1). The most Intense alteration occurs in the north-central portion of the alteration zone and decreases outward towards its margin. Within the zone lava flows of the "unnamed igneous complex" are decomposed and bleached to a light brown color and zeolitized with heulandite crystals measuring over $1 \mathrm{~cm}$ in length. Younger lava flows of the strawberry Volcanics have been bleached to a light green color and consist of clay minerals, chlorite, zeolites and minor amounts of cinnabar. This alteration zone lies along a falt zone and may be attributed to the sulfutaric action of hot springs. The youngest rocks within the zone are basalt flows of the Strawberry Volcanics, Indicating that alteration was less than about $10 \mathrm{~m}$ y ago.

Further southeastward along the fault zone, in the SW $1 / 4$ sec. 16, T. 18 S., R. 37 E., patches of bare ground are covered with white salts, possibly sulphates. Rocks of the Juntura Formation are locally silfcified and silfcous sinter occurs over an area of $0.5 \mathrm{~km}^{2}$ around two hot springs where Warm Springs Creek enters Beulah Reservolr. Another hot spring flows out of stream gravels on the east side of the North Fork of the Malheur River upstream from where 1 enters Beulah Reservolr. Spring temperatures are about $70^{\circ} \mathrm{C}$. A $1-$ though there are no recent volcanic rocks within the castle Rock area, hot springs and hydrothermal alteration indicate that the region is not totally inactive. 


\section{STRUCTURAL GEOLOGY}

\section{INTRODUCTION}

The Castle Rock area lies within a zone of changing structural trends. South of the area faults and folds trend north-south. Structural elements within the Castle Rock area and to the west have a we11-developed north-northwest orientation. There is a less we11-developed north-northeast orfentation of some structural elements in the eastern part of the Castle Rock area. These elements become better developed towards the east.

The Castle Rock ridge is a major structural high which extends from Hunter Campground through the center of the area to Black Butte (Plate 1, Cross Sec. A \& B). This ridge has been uplifted along faults on all sides to form a horst. Emplacement of the Castle Rock dike is belleved to be related to this uplift. Major structural lows are: the valley of the North Fork of the Malheur River, the Beulah Reservolr area and the area of subsidence around Black Butte.

\section{FOLDING}

Two major north-northwest trending folds are represented by the Castle Rock anticline and the North Fork of the Malheur River syncline (Plate 1, Cross Sec. B). The anticline and syncline have widths of $6 \mathrm{~km}$ and $5 \mathrm{~km}$, respectively, and 
lengths exceeding $10 \mathrm{~km}$ extending outside of the mapped area to the northwest.

The Castle Rock anticline has an amplitude of about $430 \mathrm{~m}$, and $1 \mathrm{~s}$ asymmetric with an axial plane inclined steeply eastward. At Jerry Canyon the crest of the fold has formed along a longltudinal fault zone (Plate 1 , cross Sec. $A \& B)$. The western $11 \mathrm{mb}$ of the anticline dips 8 to 19 degrees; the eastern $11 \mathrm{mb}$ dips as steeply as 28 degrees; and the nose of the fold plunges about 35 degrees southward. North of the Castle Rock Fire Guard Station the anticline plunges about 15 degrees northward.

The North Fork of the Malheur River syncline is also asymmetrical with an axial plane steeply inclined eastward. The southwest and northeast IImbs of the syncline have average dips of 10 to 15 degrees, respectively, and the fold plunges about 12 degrees to the southeast (PIate 1, Cross Sec. B). South of Castle Rock this syncline terminates In the fault-bounded basin occupled by Beulah Reservolr. This fault zone continues southward along the North Fork of the Malheur River, forming a graben-like structure, bounded on both sides by high angle normal faults. The fault zone continues into the Juntura Basin and extends southward along the South Fork of the Malheur River, forming a fault zone several kllometers wide (Haddock, 1967). This syncline merges or trends into a high angle normal fault about $15 \mathrm{~km}$ northwest of the Castle Rock area and extends northwestward 
Into the area of Prairie city, merging with the axis of the John Day Syncline (Lowry, 1968).

Folding within the Castle Rock area may predate some faulting and be contemporaneous with younger faulting. Attitudes change abruptly in the flanks of major folds where sma11-scale faulting disrupts bedding (FIg. 24; Plate 1, Cross Sec. B).

\section{FAULTING}

Normal faults are Important structures within the Castle Rock area. Several northwest trending normal faults are exposed east of Goodwin's Tomb near Irish Spring, forming a serles of stepped blocks (F1g. 25).

A reverse fault of uncertain displacement was mapped on the ridge northeast of Castle Rock In sec. 3, T. $18 \mathrm{~S} ., \mathrm{R}$. 37 E. Two other faultg on the same ridge across from Hunter Campground also appear to have reverse displacement.

Many faults within the Castle Rock area are gradational between normal faults and hinge faults. Faults with hinge displacement generally show a flexure at right angles to the fault plane, representing the axial trace of the hinge. Such faults are best exposed on the west side of the North Fork of the Malheur River and the southeast end of Jerry Canyon.

\section{STRUCTURAL SYNTHESIS}

Evidence separating structural events from deposition of volcanic formations was not found. The youngest Juntura 


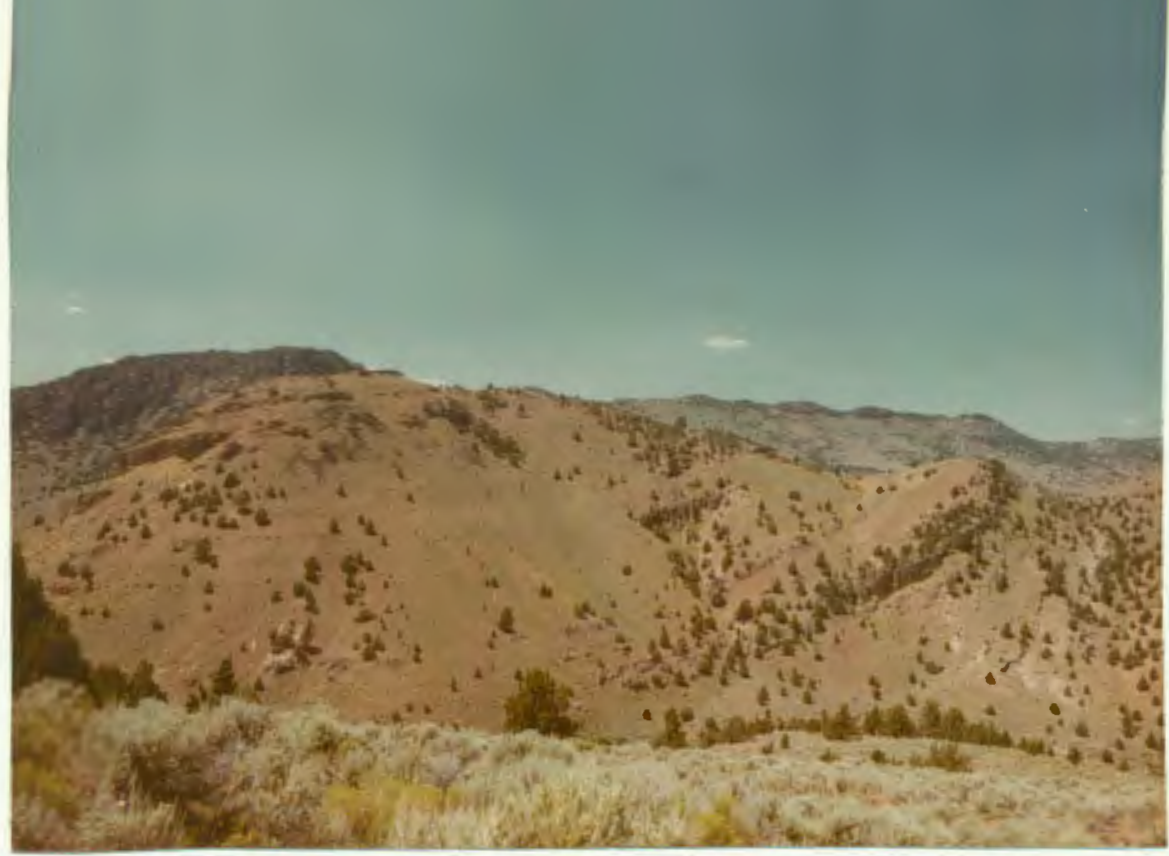

Figure 24. Small scale normal faulting disrupting strata of the Strawberry Volcanics along Lost Creek, looking southwestward with Black Butte in the background. Vertical displacement is about $5 \mathrm{~m}$, west side down. Note the abrupt change in attitudes of beds at the fault plane.

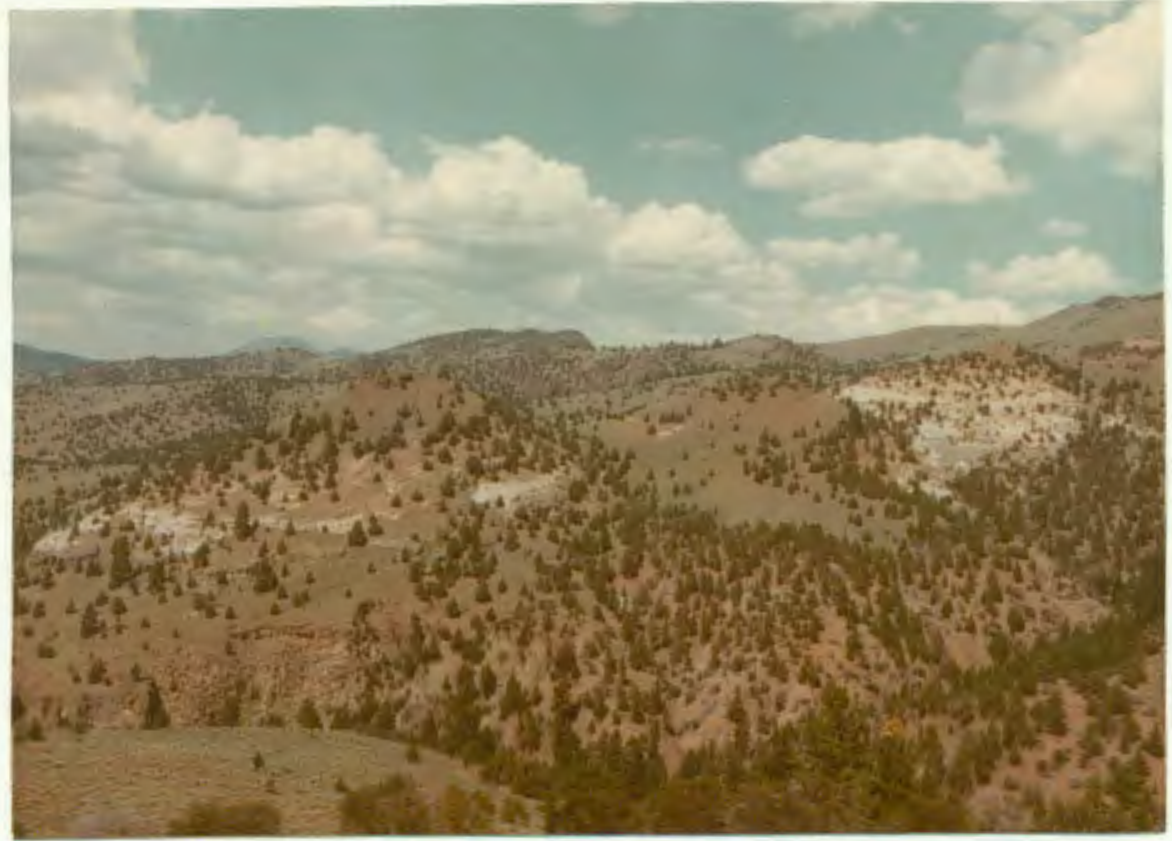

Figure 25. A series of stepped fault blocks east of Goodwin's Tomb near Irish Spring, looking northward with Ironside Mountain in the distance. Strata of the Strawberry Volcanics are cut by normal faults inclined about 60 degrees northeastward. Displacement on each fault is about $40 \mathrm{~m}$. 